SERI/TP-231-3622

UC Category: 249

DE90000367

\title{
Assessment of Municipal Solid Waste for Energy Production in the Western United States
}

B.J. Goodman

R.H. Texeira

August 1990

Prepared for:

The Western Regional Biomass Energy Program Under Task No. BF981011

Solar Energy Research Institute

A Division of Mldwest Research institute

1617 Cole Boulevard

Golden, Colorado 80401-3393

Prepared for the

U.S. Department of Energy

Contract No. DE-ACO2-83CH10093 


\section{NOTICE}

This report was prepared as an account of work sponsored by an agency of the United States government. Neither the United States government nor any agency thereof, nor any of their employees, makes any warranty, express or implied, or assumes any legal liability or responsibility for the accuracy, completeness, or usefulness of any information, apparatus, product, or process disclosed, or represents that its use would not infringe privately owned rights. Reference herein to any specific commercial product, process, or service by trade name, trademark, manufacturer, or otherwise does not necessarily constitute or imply its endorsement, recommendation, or favoring by the United States government or any agency thereof. The views and opinions of authors expressed herein do not necessarily state or reflect those of the United States government or any agency thereof.

Printed in the United States of America

Available from:

National Technical Information Service

U.S. Department of Commerce

5285 Port Royal Road

Springfield, VA 22161

Price: Microfiche A01

Printed Copy A06

Codes are used for pricing all publications. The code is determined by the number of pages in the publication. Information pertaining to the pricing codes can be found in the current issue of the following publications which are generally available in most libraries: Energy Research Abstracts (ERA); Government Reports Announcements and Index GRA and I); Scientific and Technical Abstract Reports (STAR); and publication NTIS-PR-360 available from NTIS at the above address. 


\section{Preface}

This report was prepared for the Western Area Power Administration (WAPA). WAPA manages the Western Regional Biomass Energy Program (WRBEP) for the U.S. Department of Energy. WRBEP established an Ad Hoc Resource Committee to determine the most appropriate feedstocks to be considered for energy production in the 13-state western region. This report is designed to provide the committee members with information to assist them in making this determination. 


\section{Table of Contents}

$1.0 \quad$ Introduction $\ldots \ldots \ldots \ldots \ldots \ldots \ldots \ldots \ldots \ldots \ldots \ldots \ldots \ldots$

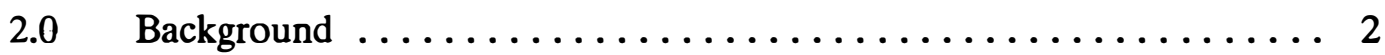

3.0 Population and Economy of the Region $\ldots \ldots \ldots \ldots \ldots \ldots$

$4.0 \quad$ Generation and Landfill Capacity .................. 11

5.0 Current Utilization of MSW $\ldots \ldots \ldots \ldots \ldots \ldots \ldots \ldots \ldots \ldots$

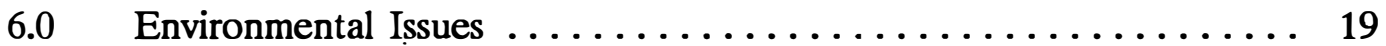

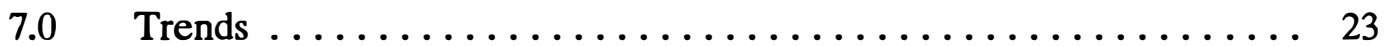

Appendices

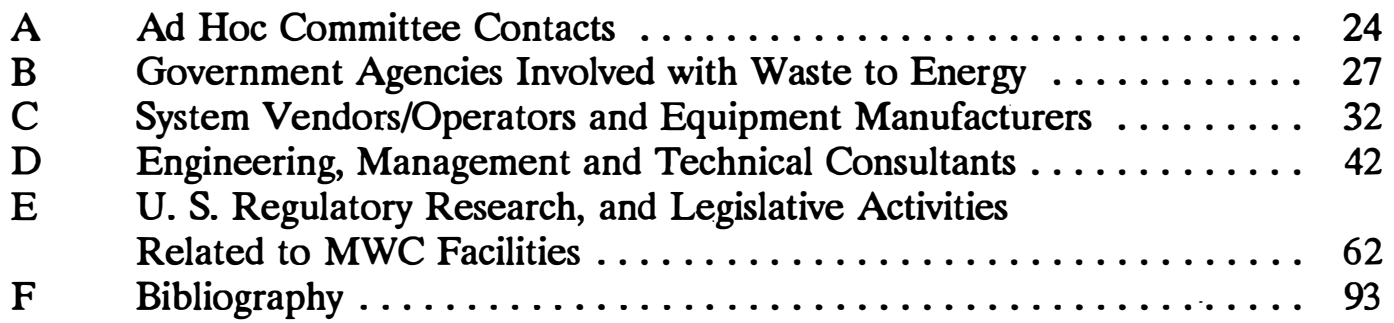




\section{List of Figures}

Page

2-1 Materials discarded into the municipal waste stream in 1986

(percentage of total) $\ldots \ldots \ldots \ldots \ldots \ldots \ldots \ldots \ldots \ldots \ldots \ldots \ldots$

3-1 Population data for region $\ldots \ldots \ldots \ldots \ldots \ldots \ldots \ldots \ldots$

4-1 State landfill capacity $\ldots \ldots \ldots \ldots \ldots \ldots \ldots \ldots \ldots \ldots \ldots \ldots$

5-1 MSW energy recovery options $\ldots \ldots \ldots \ldots \ldots \ldots \ldots \ldots \ldots \ldots$

5-2 Location of waste-to-energy plants $\ldots \ldots \ldots \ldots \ldots \ldots \ldots \ldots$

5-3 Primary energy form: planned and existing facilities $\ldots \ldots \ldots \ldots \ldots 17$ 


\section{List of Tables}

Page

2-1 Materials Discarded into the U.S. Municipal Waste Stream 1970-2000 . 2

4-1 MSW Generation, Tipping Fee, and Electricity Cost for Region . . . . . 11

4-2 Projected Landfill Closings, $1988-2000 \ldots \ldots \ldots \ldots \ldots \ldots \ldots$

4-3 U.S. Solid Waste Management .................. 12

5-1 Waste-to-Energy Projects in the United States . . . . . . . . . . 15

5-2 Current Waste-to-Energy Processes for the United States . . . . . . . 16

5-3 Distribution of Waste-to-Energy Projects $\ldots \ldots \ldots \ldots \ldots \ldots$

$5-4 \quad$ Type of Process of Western Region $\ldots \ldots \ldots \ldots \ldots \ldots \ldots \ldots$

5-5 Waste-to-Energy Facilities in Western Region $\ldots \ldots \ldots \ldots \ldots \ldots$

5-6 Existing/Planned Waste-to-Energy Facilities in the Western Region . . 18

6-1 Pollution Control Equipment $\ldots \ldots \ldots \ldots \ldots \ldots \ldots \ldots \ldots \ldots$

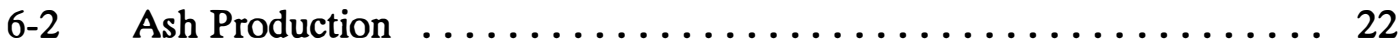

7-1 Timing of the Waste-to-Energy Project Development Process . . . . . . 23 


\subsection{INTRODUCTION}

Approximately 250 million tons of municipal solid waste (MSW) are generated by the residential, institutional, and industrial sectors of this country each year. Every individual in the United States produces approximately $3.5-5.0 \mathrm{lb}$ of MSW daily. This represents a significant national environmental problem, but also a potentially valuable resource for renewable energy production. Aside from industrial discards, the Environmental Protection Agency (EPA) estimates that residential and commercial wastes account for approximately 160 million tons. This amount is constantly increasing; the figure is projected to reach about 198 million tons by the year 2000 .

The Western Area Power Administration (WAPA) manages the Western Regional Biomass Energy Program (WRBEP) for the U. S. Department of Energy. The western region encompasses Arizona, California, Colorado, Kansas, Nebraska, Nevada, New Mexico, Oklahoma, North Dakota, South Dakota, Texas, Utah, and Wyoming. To determine the most appropriate feedstocks to be considered for energy production in this 13-state region, WRBEP established an Ad Hoc Resource Committee. At their meeting, the committee members requested information on the status of MSW in these states, including economic and environmental issues. This report is designed to provide the committee members with data to assist them in determining the potential for using MSW to produce energy in this region.

The background section covers general information on MSW. Section 3.0 gives data on population and population density for each of the 13 states, as well as information on the economy of these states. Data on the amount of MSW generated in each state and information on each state's landfills are included in Section 4.0. Section 5.0 discusses options for energy recovery from MSW and current waste-to-energy facilities in this region. Environmental issues, including federal regulations, state regulations (where available), and public opinion, are discussed in Section 6.0. Specific conclusions and/or recommendations are not made in this report, as the intent of this document was simply to provide the Ad Hoc Committee with information. However, some general trends are noted in Section 7.0. Appendix A provides names, addresses, and phone numbers for the Ad Hoc Committee members contacted in compiling this report. Federal and state government agencies involved in waste to energy are listed in Appendix B. Appendix $C$ lists system vendors/operators and equipment manufacturers. Engineering, management, and technical consultants in the municipal waste field are listed in Appendix D. A paper describing U.S. regulatory, research, and legislative activities related to municipal waste combustion facilities is included as Appendix E. Appendix F is a bibliography of resources used in preparing this report. 


\subsection{BACKGROUND}

Information regarding the quantities and composition of MSW is required for appropriate solid waste management. There is no "typical" composition of MSW because it varies from season to season, location to location, and day to day. However, historical and projected quantities of materials in the U.S. municipal waste stream have been provided by Franklin Associates, Limited, and are shown in Table 2-1 below.

Table 2-1. Materials Discarded into the U.S. Municipal Waste Stream 1970-2000* (in millions of tons)

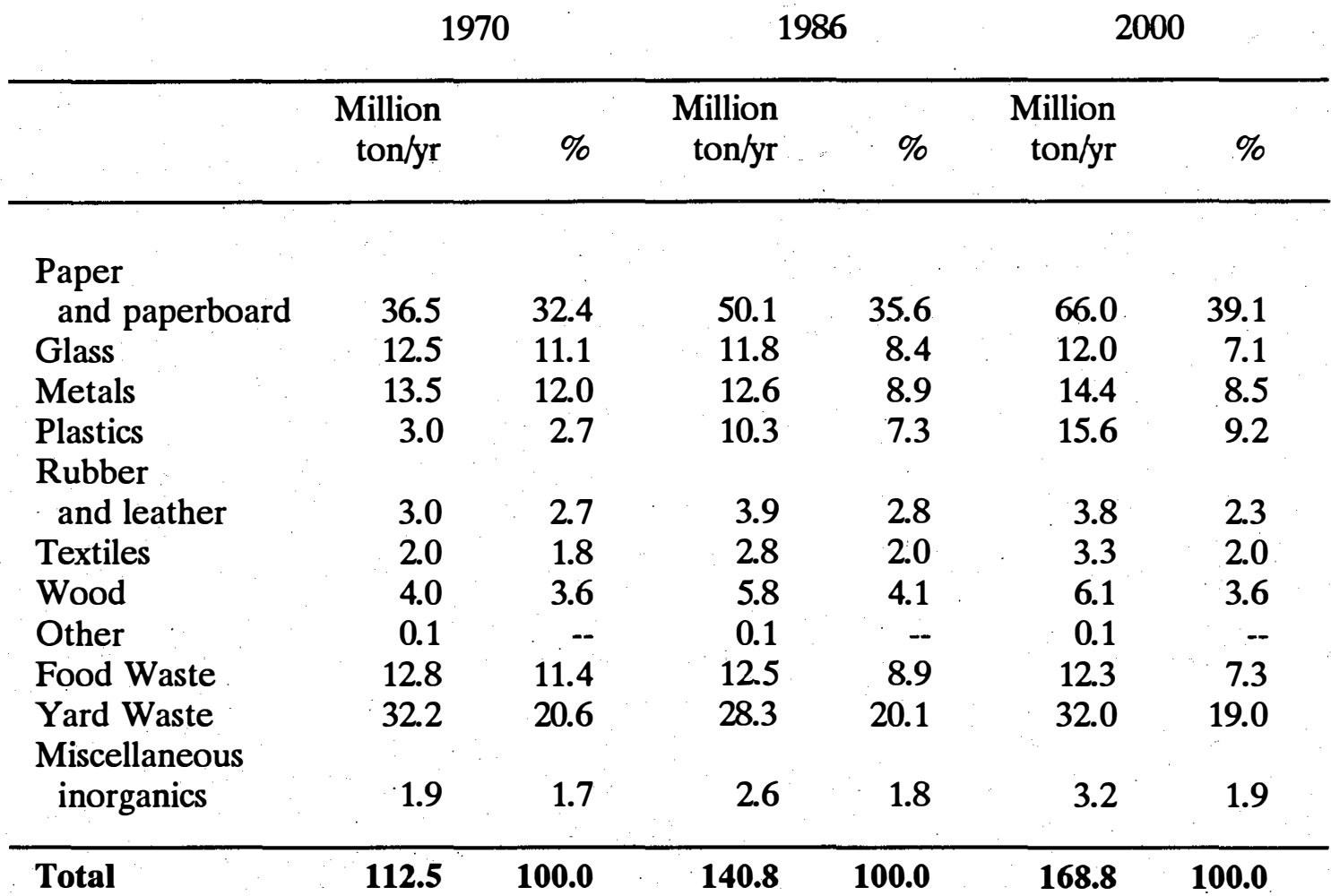

"Wastes discarded after materials recovery and before energy recovery.

The relative magnitude of the various materials in the municipal waste stream is illustrated in Figure 2-1. The largest fraction of MSW is paper and paperboard, followed by yard waste. The next most significant component, called "other," varies greatly depending on the source of the MSW and the season. Food waste and metals are approximately the same percentage of MSW, followed by glass, plastics, and miscellaneous inorganic materials. A few comments on each of the materials follow. 


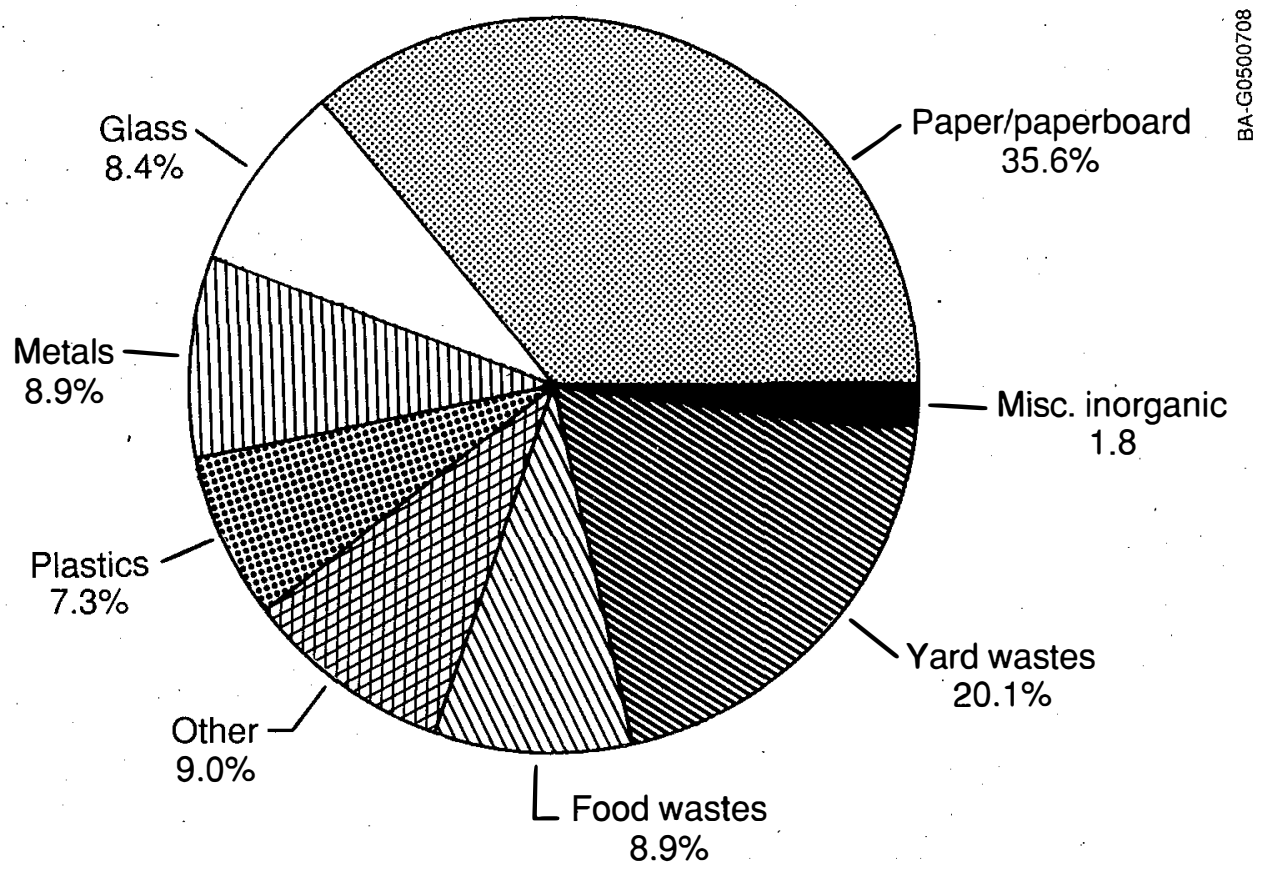

Figure 2-1. Materials discarded into the municipal waste stream in 1986 (percentage of total)

Paper and Paperboard. Paper and paperboard make up the largest category of MSW, ranging from 24.5 million tons disposed in 1960 to 50 million tons disposed in 1986. Paper and paperboard discards are projected to reach 66 million tons by 2000 . Paper's share of municipal waste stream discards has ranged from $30 \%$ to $35 \%$ over the past quarter of a century. The upward trend is projected to continue.

Glass. The percentage of tons of glass (mostly containers) in the waste stream increased steadily until the early 1980s, then began to fall slowly. Glass comprised $8 \%$ in 1960 , rising to more than $11 \%$ in the early 1980s, then falling to $8 \%$ in 1986 . The percentage of glass in the waste stream is projected to fall to under $8 \%$ by 2000 because of increased recycling efforts and the increased use of plastic containers.

Ferrous Metals. Currently, ferrous metals total about 11 million tons in the waste stream. The ferrous metals tonnage has remained fairly constant over the years; thus, as a percentage of the total, ferrous metals have decreased. This trend is projected to continue.

Aluminum. Aluminum in the municipal waste stream has increased steadily, but the tonnage of this light metal is still very small -- only 1.7 million tons in 1986. In percentage, aluminum has grown from less than $1 / 2$ of $1 \%$ in 1960 to just over $1 \%$ in 1986. This trend is expected to continue, possibly because of effective recycling efforts for this material. 
Other Nonferrous Metals. Metals such as copper and brass comprise a very small share of the municipal waste stream -- less than $1 \%$. Their tonnage has been about 300,000 tons in recent years; this is projected to increase to 400,000 tons by 2000 .

Plastics. Plastics in the waste stream have increased steadily, from approximately one-half million tons in 1960 to more than 10 million tons in 1986. This trend is expected to increase to 15.6 million tons in 2000.

Rubber and Leather. This category, which includes rubber tires, grew in tonnage from 1.7 million tons in 1960 to 4.1 million tons in 1981. Since then, tonnage has been declining, and any growth is expected to be very slow. Rubber and leather have ranged from $2.1 \%$ to $3.2 \%$ of the waste stream, and the percentage is projected to remain fairly constant at about $3 \%$.

Textiles. Textiles have stayed at a fairly constant $2 \%$ of the municipal waste stream. Tonnage has ranged between 2 million and 3.4 million tons.

Wood. Wood in the municipal waste stream was estimated at 3 million tons in 1960, increasing to 5 million tons in the early 1980s, and continuing to grow slowly to 6 million tons in 2000 . The percentage of wood has been about $4 \%$ or slightly less of the total.

Food Wastes. Disposal of food wastes in the United States is poorly documented compared to other product wastes. However, food wastes are estimated to have increased from 12.2 million tons in 1960 to 13.4 million tons in 1975 . Thereafter, food wastes are estimated to show a slightly decreasing tonnage, to 12.3 million tons by 2000 . In terms of percentage of net discards in the waste stream, food wastes are estimated to have fallen from nearly $15 \%$ in 1960 to about $9 \%$ in 1986 . They are projected to decrease to about $7 \%$ in 2000 , mainly because of increased home garbage disposal use.

Yard Wastes. Like food wastes, yard wastes are not well documented, and they vary widely from region to region. Based on previous work and sampling studies, yard wastes are estimated to have been 20 million tons in 1960, increasing to 28.3 million tons in 1986. They are projected to reach 32 million tons by 2000. Percentage of total decreased from about $24 \%$ in 1960 to about $20 \%$ in 1986.

Miscellaneous Inorganic Wastes. This category, composed mostly of stones and dirt, is also poorly documented. The tonnage increased slowly from 1.3 million tons in 1960 to 2.6 million tons in 1986, with a slow increase thereafter, to 3.2 million tons. This category represents less than $2 \%$ of the municipal waste stream. 


\subsection{ECONOMY AND POPULATION OF THE REGION}

The feasibility of using MSW for energy production depends on a number of factors including the economy of the area, population, and land availability. These factors for the 13-state region encompassed by WRBEP are highly variable. A brief description of the economy of each of the 13 states follows.

Arizona. Arizona's economy is sometimes characterized by the five "C's" - copper, cotton, cattle, climate, and citrus. This characterization, however, omits a vital and growing element - manufacturing.

Income from crops usually makes up somewhat more than half the total farm income. Cotton is the largest cash crop with hay, sorghum, grain, barley, corn, vegetables, and citrus fruits also contributing to the farm economy. In the livestock and livestock products category, cattle bring the largest proportion of the cash income with dairy products ranking second.

Since the 1900s, Arizona has led the United States in the production of copper. Its mines yield just over half the U.S. total. Other than copper, the metals with greatest production value are molybdenum, silver, gold, zinc, lead, and uranium. The most valuable nonmetals are sand and gravel.

Most of Arizona's economic growth since the 1950s has been in manufacturing. Important categories of manufacturing include electrical machinery, primary metals, food and food products, lumber, and wood products.

National parks and monuments attract many visitors; however, the bulk of Arizona's tourist business is centered in Phoenix and Tucson.

California. California's economy benefits from its many natural resources as well as from a mounting population. These resources have enabled the state to lead the nation in agriculture and fisheries and have placed it near the top in manufacturing, mineral and lumber production, and tourism.

Employment in manufacturing industries is the leading source of personal income in California with services, government, and wholesale and retail trade following in that order. California's favorable climate permits crops to be grown over longer periods than elsewhere. Mechanization and irrigation are widespread with many farms specializing in only one or two crops. The range of products is wide, including livestock, feed crops, food grains, cotton, vegetables, fruits, and nuts. California leads in canning, freezing, and drying of foods. It also produces approximately $85 \%$ of the nation's wines. It is the leading state in commercial fishing and fish canning and is second to Oregon in lumber production.

Engineering and production of aircraft, missiles, and television and communications equipment also contribute to California's economy. Recycling of packaging and waste materials is also an economically important activity.

Research and development as well as mining and minerals extraction contribute to California's economy. California provides the only domestic source of boron minerals and 
compounds and is also the leading world supplier for these materials. The entertainment and associated industries contribute significantly to California's economy.

Manufacturing, governmental activities, trade, and services dominate Colorado's economy, but agriculture and mining are also important. Two-fifths of Colorado's land is devoted to farming, with cattle being the primary livestock and winter wheat the most valuable single crop.

Mining and mineral extraction are important to this state's economy with petroleum being the primary fuel and molybdenum the principal metal.

Colorado is not heavily industrialized; however, manufacturing is the foundation of its wellbeing, and food processing is one of Colorado's major industries. Manufacture of machinery is also an important industry. Research and development and tourism also contribute to this state's economy.

Kansas. The economy of Kansas is diversified, with the largest number of people employed in wholesale and retail trade, followed by manufacturing, government, and service industries. Transportation equipment industries are the leading employers, and aircraft companies dominate that sector. Meat packing and milling are also important industries.

Kansas is first in wheat production and among the leaders in production of sorghum, beef, and alfalfa. The livestock industry is also of economic importance throughout the state.

Valuable deposits of petroleum, natural gas, and coal exist in Kansas.

Nebraska. Throughout its history, Nebraska has been primarily an agricultural state. In recent years, however, agricultural employment has declined and manufacturing activities have increased. More than half of Nebraska's farm income comes from the sale of livestock and livestock products. Corn is the leading crop grown in the state. Other important crops include wheat, soybeans, sorghum, and hay. Leading manufacturing industries include production of printed materials and instruments. Mining plays a relatively small role in the state's economy. Petroleum is the major mineral product of commercial importance.

Nebraska is unique among the states in that all electric utilities are publicly owned. Most electricity is produced and supplied by public power districts governed by popularly elected boards of directors.

Nevada. Tourism is the leading economic activity in Nevada, producing more than $50 \%$ of the income generated in the state. Nevada's most important agricultural activity is the raising of livestock, especially cattle and sheep. About $85 \%$ of all farm income is derived from livestock raising and feeding. Fruits and vegetables account for $11 \%$.

Minerals produced include gold, copper, silver, mercury, molybdenum, lead lithium, and tungsten. Nonmetallic minerals include barite, sand, cement, gypsum, and stone. 
Nevada is one of the leading industrialized states. Important industries include food processing, printing and publishing, metal item fabrication, and chemical production. Ore smelting is also an important activity.

New Mexico. Farming was the dominant economic activity in New Mexico until the 1940s, when it was surpassed by mining, now the foremost economic activity. Natural gas and petroleum are the state's most valuable minerals. Coal production is also important. New Mexico has about $40 \%$ of the nation's total reserves of uranium. Copper, molybdenum, potash, gold, and silver are also mined.

There are more ranches than farms in New Mexico, and cattle are the main livestock. Hay and wheat are the leading cash crops.

North Dakota. Agriculture is the basis of North Dakota's economy; however, mining, manufacturing, and tourism are also important. North Dakota ranks first among the states in production of spring wheat, durum wheat, barley, sunflower seed, and flaxseed. Many North Dakota farmers gain additional income by raising hogs and sheep.

Lignite coal is North Dakota's most valuable mineral resource. Petroleum and natural gas also contribute to the mining income of the state.

Oklahoma. Oklahoma's economy is a balance of agriculture, mining, and manufacturing. Livestock is responsible for the greatest portion of farm income in Oklahoma; winter wheat is second. Minerals and mining are focused on oil and natural gas. Other than fuels, important minerals include cement, stone, sand, and gravel. The most important industries today are the manufacture of nonelectrical machinery, fabricated metals, rubber and plastic products, petroleum and coal products, and electrical equipment.

South Dakota. Agriculture is the economic mainstay of South Dakota with manufacturing, tourism, and mining contributing a lesser, but significant, share. Approximately $70 \%$ of all farm receipts comes from the sale of livestock and livestock products. Only $20 \%$ comes from the sale of crops.

Meat-packing and processing industries have grown in South Dakota. Mining operations also contribute to the economy with gold being the most profitable.

Texas. Texas traditionally leads the nation in production of livestock, cotton, and grain sorghum. The quality of its beef cattle is renowned. The state ranks first in value of mineral production, and its petroleum-related industries continue to grow.

Texas ranks fourth in the nation in total farm income with almost $85 \%$ of the land used for farms and ranches. Agricultural income is equally divided between livestock, poultry, and crop production.

More than $90 \%$ of the total value of the state's mineral production is from mineral fuels such as petroleum and natural gas. Texas is also one of the leading states in the production of sulfur, helium, salt, and cement. 
Manufacturing varies in Texas from processing of natural resources and agricultural products to machinery manufacturing. Tourism has also become a major source of income for Texas.

Utah. Beef and dairy products are important in Utah. Hay, winter wheat, and barley are Utah's chief crops. Mink raising in Utah ranks third in the nation.

Utah's most important industrial activity is the manufacture of electrical machinery. Other leading industries include the manufacture of guided missiles and space vehicles, food processing, and the production of electrical equipment.

Petroleum is Utah's most valuable mineral followed by coal, copper, and natural gas. Gold, silver, and salt are also produced in significant quantities.

Tourism also contributes to the state's economy.

Wyoming. Wyoming is the least industrialized state in the nation. Mining is the most important industry, and petroleum is its major product. Wyoming is the nation's leader in uranium production. Coal production is a rapidly expanding industry. Ranching is the state's second most important industry. Principal crops are beans, sugar beets, alfalfa, hay, oats, barley, corn, and potatoes. Almost all the manufacturing is related to petroleum, uranium, and coal processing. Food processing and manufacture of flight equipment also contribute to the economy.

Because the economy of this region is so diverse, generalizations about similarities within the waste stream are difficult to make. However, agriculture, manufacturing, mining, and tourism appear to be the most important in this region. The number of people in a given area closely correlates to the amount of municipal waste generated. Figure 3-1 shows population data for each of the 13 states encompassed by WRBEP. It is interesting to note that in this region the states with the largest populations tend to be the states with the largest area, in contrast to the situation in the Northeast. This may be why we have not seen as much attention being given to waste-to-energy projects in the western United States as in the Northeast. 

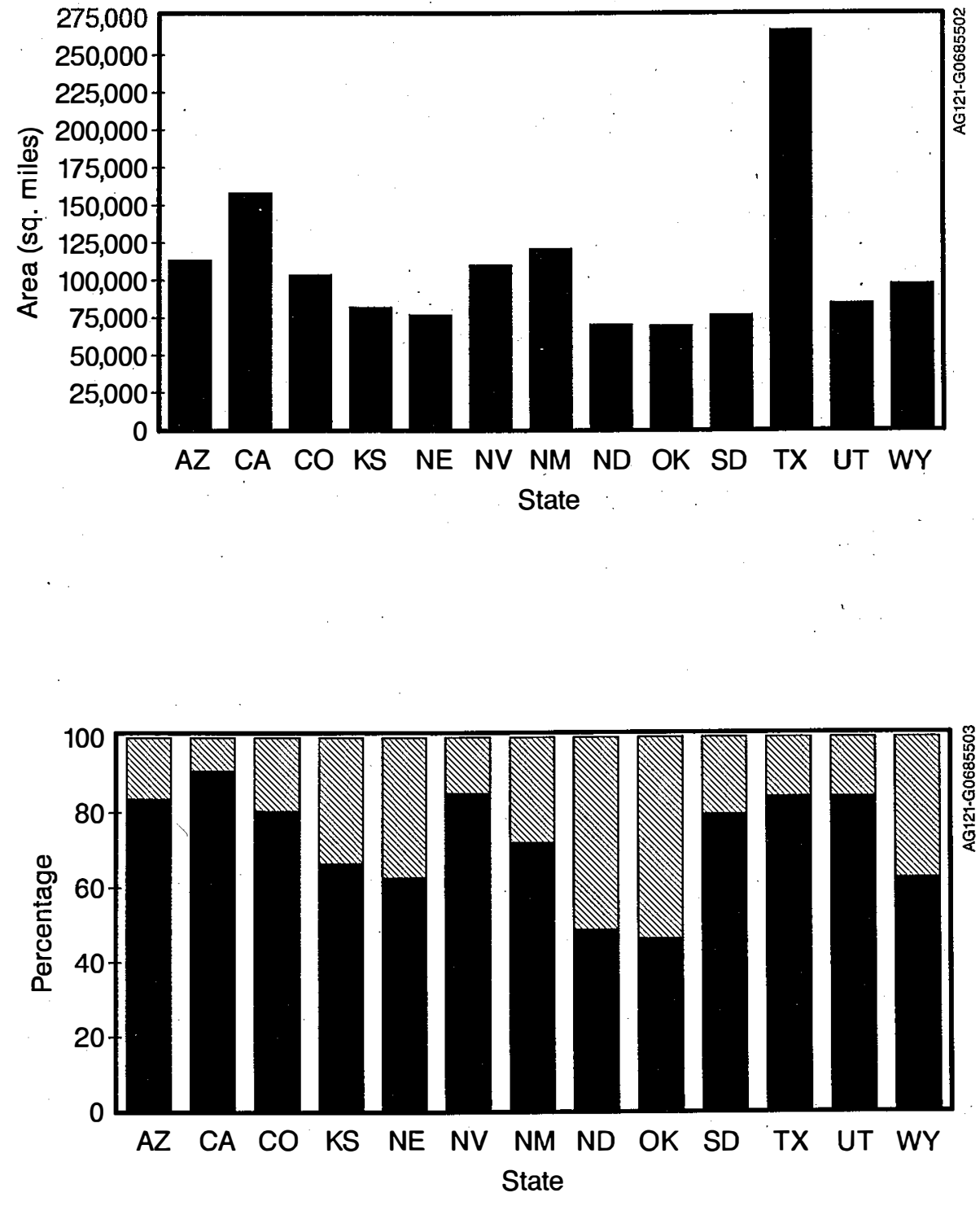

Urban

Rural distribution

Figure 3-1. Population data for region 


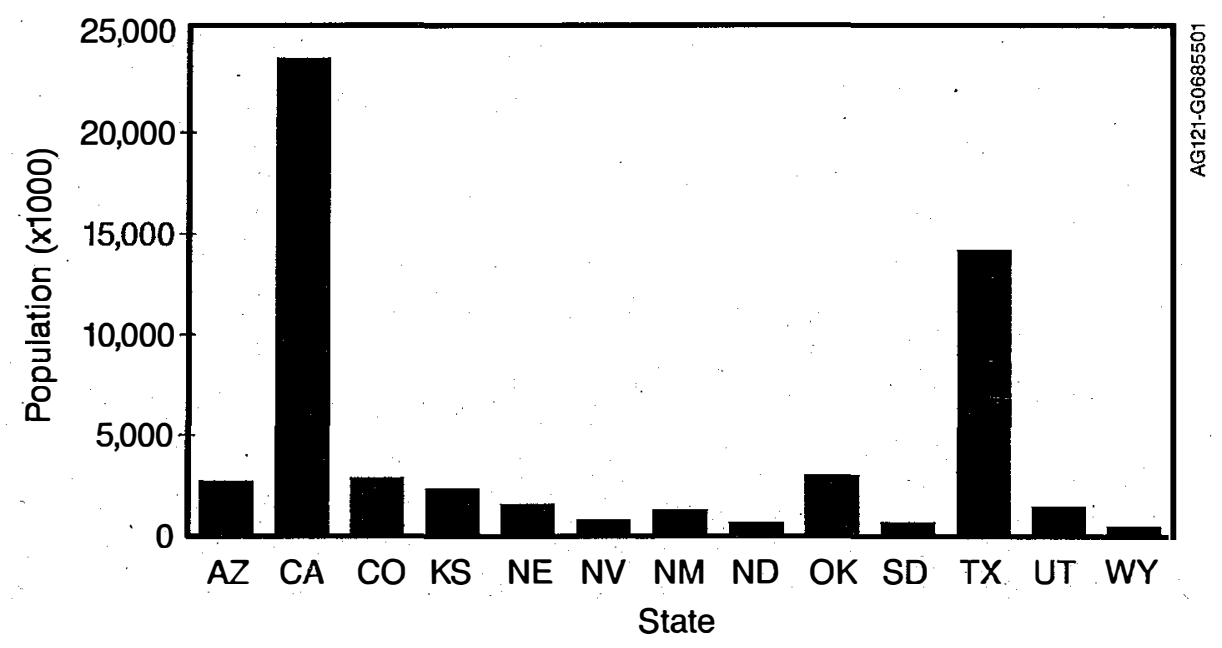

Figure 3-1. Population data for region (Concluded) 


\subsection{GENERATION \& LANDFILL CAPACITY}

According to the National Solid Waste Management Association (NSWMA) Annual Tipping Fill Survey, the 1988 average at landfills was $\$ 26.93$ per ton, up $32.3 \%$ from the 1987 figure. At waste-toenergy facilities, this average was $\$ 39.86$ per ton. Based on discussions with the members of the Ad Hoc Committee for WRBEP and information available in the literature, Table 4-1 was compiled. It summarizes the amount of MSW generated per day for each of the 13 states, assuming an average production of $4.0 \mathrm{lb}$ per person per day, along with the average or range of tipping fee and cost of electricity for each state.

Table 4-1. 'MSW Generation, Tipping Fee, and Electricity Cost for Region

\begin{tabular}{lccc} 
State & $\begin{array}{c}\text { MSW Generation } \\
\text { (tons/day) }\end{array}$ & $\begin{array}{c}\text { Tipping Fee } \\
(\$ / \text { ton })\end{array}$ & $\begin{array}{c}\text { Cost of } \\
\text { Electricity } \\
(\notin / \mathrm{kwh})\end{array}$ \\
\hline Arizona & 5,433 & $7-25$ & $9-10$ \\
California & 47,336 & $3-20$ & $\mathrm{~N} / \mathrm{A}$ \\
Colorado & 5,779 & $2-14$ & 6.5 \\
Kansas & 4,728 & $3-17$ & 7.5 \\
Nebraska & 3,140 & $5-13$ & $4-7$ \\
Nevada & 1,601 & 10 & $5-8$ \\
New Mexico & 2,607 & $0-12$ & 10 \\
North Dakota & 1,305 & $\mathrm{~N} / \mathrm{A}$ & $\mathrm{N} / \mathrm{A}$ \\
Oklahoma & 6,051 & 20 & $\mathrm{~N} / \mathrm{A}$ \\
South Dakota & 1,382 & $0-10$ & $3-7$ \\
Texas & 28,451 & $6-15$ & 8 \\
Utah & 2,922 & $6-35$ & $6-8$ \\
Wyoming & 939 & 1 & 3
\end{tabular}

According to the EPA's latest calculations, half our nation's landfills will be closing by 1995 , leaving large amounts of refuse without local disposal options. Current construction rates are expected to add only about four million tons per year of new capacity, which may force many communities to ship their waste to distant sites at large costs. Table 4-2 shows EPA's projection for landfill closings for 1988 to 2000.

Currently, $75 \%$ of our garbage is deposited in landfills, while $11 \%$ is recycled and $13 \%$ is burned in waste-to-energy plants. Table 4-3 shows historical and projected trends in solid waste management as given by Governmental Advisory Associates.

Americans are putting increased emphasis on source reduction, recycling, and resource recovery. Source reduction is an attempt to reduce the volume of trash before it is produced. In addition, problematic materials such as lead and cadmium need to be minimized in manufacturing processes to decrease threats to groundwater when discarded. 
Table 4-2. Projected Landfill Closings, 1988-2000

\begin{tabular}{ccc} 
Year & $\begin{array}{c}\text { Operating } \\
\text { Landfills }\end{array}$ & $\begin{array}{c}\text { Annual Intake* } \\
\text { (millions of tons) }\end{array}$ \\
\hline 1988 & 5,499 & 187 \\
1993 & 3,332 & 131 \\
1998 & 2,720 & 94 \\
2000 & 2,157 & 76
\end{tabular}

*Includes industrial and other wastes deposited in solid waste landfills.

Table 4-3. U.S. Solid Waste Management

\begin{tabular}{lcccccccc} 
& 1960 & & 1970 & & 1988 & 2000 & \\
& Volume* & $\%$ & Volume & $\%$ & Volume & $\%$ & Volume & $\%$ \\
\hline Landfills & 81.7 & 93 & 112.1 & 93 & 119.8 & 76 & 96.3 & 50 \\
$\begin{array}{l}\text { Recycle } \\
\text { Waste-to- }\end{array}$ & 5.8 & 7 & 8.0 & 7 & 17.3 & 11 & 48.2 & 25 \\
Energy & - & - & 0.4 & $<1$ & 20.5 & 13 & 48.2 & 25 \\
\hline Total & $\mathbf{8 7 . 5}$ & $\mathbf{1 0 0}$ & $\mathbf{1 2 0 . 5}$ & $\mathbf{1 0 0}$ & $\mathbf{1 5 7 . 6}$ & $\mathbf{1 0 0}$ & $\mathbf{1 9 2 . 7}$ & 100 \\
\hline
\end{tabular}

*in millions of tons per year

Many communities are able to recover $20 \%$ to $25 \%$ of their residential and commercial waste through recycling. Such wastes include glass bottles, cardboard and paper, aluminum cans, and other materials. If these programs are to succeed, viable and stable markets for these materials are required. Waste-to-energy plants reduce the remaining volume of waste by $90 \%$. These plants use state-of-the-art pollution control equipment to protect the environment and recover the heating value of garbage as steam or electricity. Proper landfilling of remaining wastes and ash from waste-toenergy plants is still required.

Most solid waste landfills are owned by local jurisdictions and tend to be small sites located in rural or outlying areas. Private landfills represent $14 \%$ of the total, but include half the country's existing disposal space. But size and volume are not the only factors determining landfill capacity. Tougher environmental regulations are forcing older landfills to close regardless of how full they are. Five states -- California, Maine, New York, Texas, and Wisconsin -- now include about $40 \%$ of all MSW landfills in the United States. EPA estimates that landfill space throughout the United States will largely be exhausted within ten years; while most urban centers in the Northeast and Great Lakes 
region will run out by 1993. Without additional construction, remaining capacity will be mismatched with the places where most people live. These communities will have to ship their wastes to other landfills at high costs. The states included in WRBEP's region may be forced to accept these wastes in spite of the public "not in my backyard" syndrome.

Figure 4-1 shows landfill capacity by state and clearly indicates greater availability in the western part of the United States than many other areas of the country. Current legislation has been introduced to restrict the amount of waste that can be shipped across state lines, but there has been no definitive resolution to this situation.

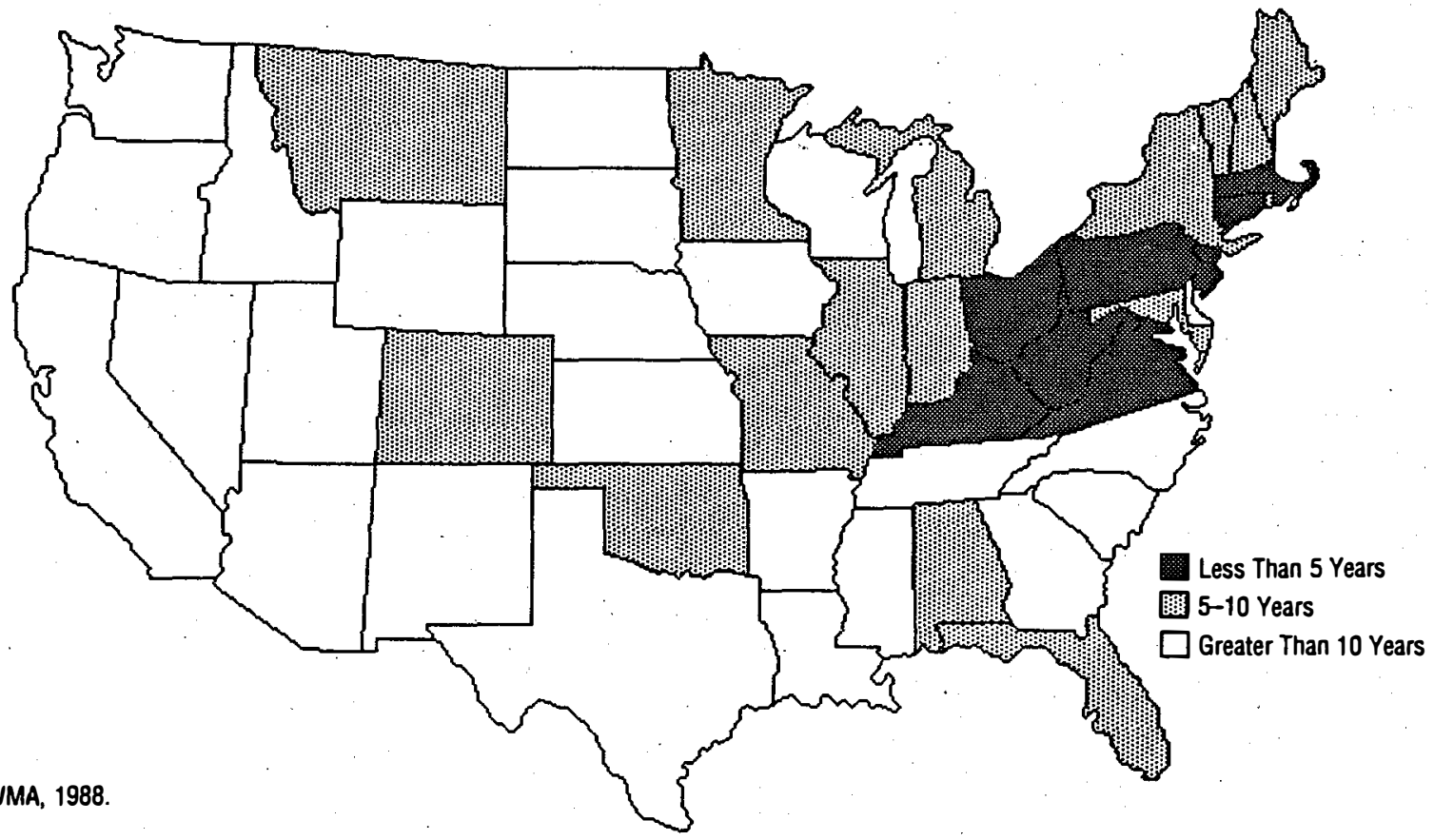

Figure 4-1. State landfill capacity 


\subsection{CURRENT UTILIZATION OF MSW}

There are a number of energy recovery options for converting the organic components of the municipal waste stream into useful energy products. Figure 5-1 shows some traditional approaches as well as longer term alternatives still in the research and development (R\&D) stage. Traditionally, waste has been deposited into landfills where microorganisms degrade the organic components to methane and carbon dioxide. Recent efforts to produce energy from MSW utilize mass burn technology to produce steam and/or electricity; other options are still being researched.

Currently, more than 100 waste-to-energy plants are operating in the United States. These plants burn refuse at high temperatures and reduce its volume by as much as $90 \%$. These facilities receive about $13 \%$ of the U.S. waste stream and produce an ash residue, which must be buried in appropriate landfills. A major advantage of these facilities is that they produce steam or electricity to help offset the cost of construction.

Table 5-1 breaks the solid waste projects in the United States into three categories: the advanced planning to operational stage includes 202 facilities that are all in advanced stages of planning (under

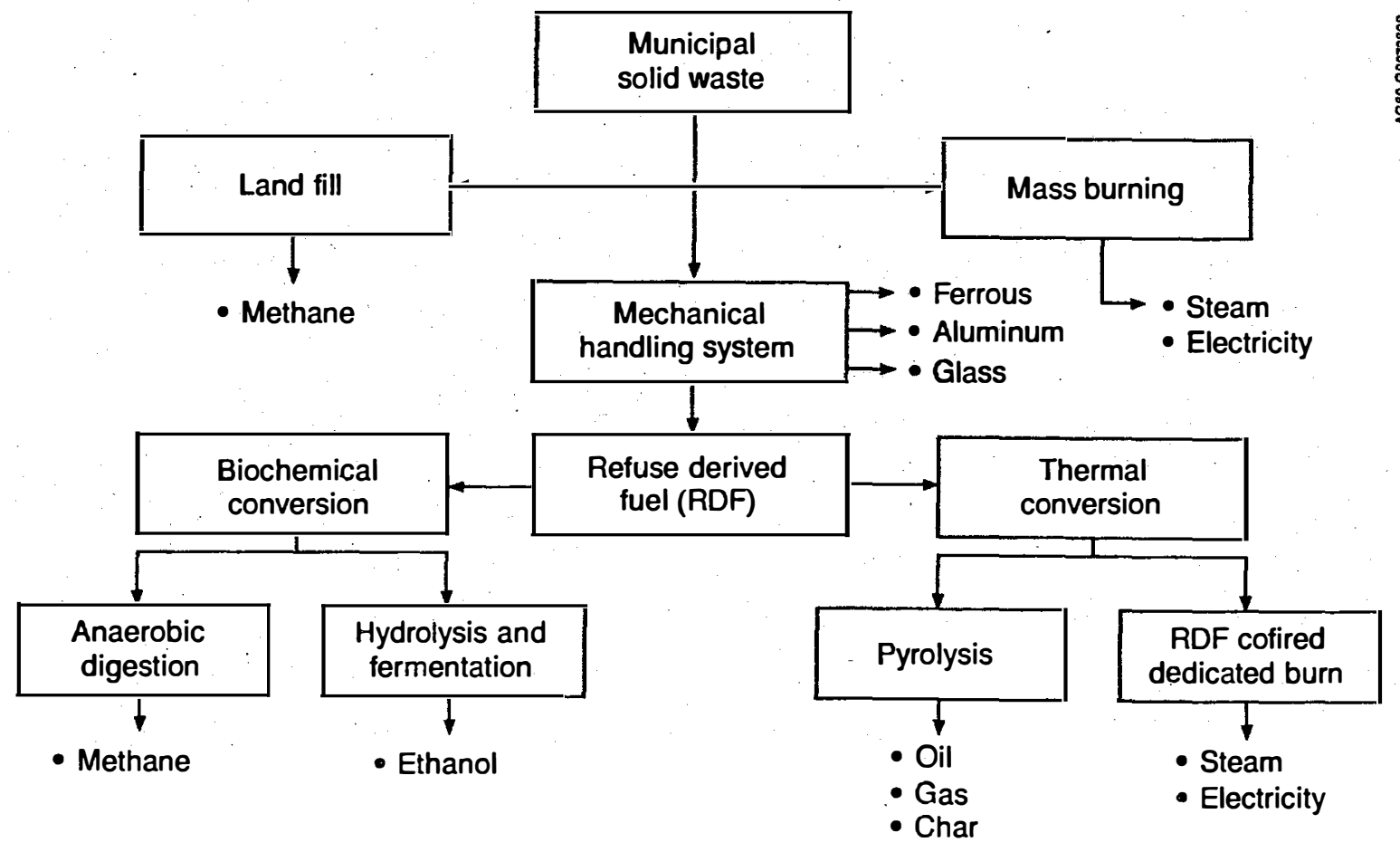

Figure 5-1. MSW energy recovery options 
Table 5-1. Waste-to-Energy Projects in the United States

Advanced Planning to Operational Stage

Conceptual Stage

Permanently Shut Down

Total

construction, operational, and/or temporarily shut down for the purpose of retrofitting). These facilities have secured construction or full-service contracts and have developed construction schedules. The 139 projects in the conceptual stage have completed feasibility studies, requests for qualification (RFQ), or requests for proposals (RFP). The 27 facilities that are permanently shut down closed mainly because of equipment problems, followed by unfavorable economics and environmental problems.

Figure 5-2 shows the locations of existing waste-to-energy facilities. The greatest concentrations are in the Northeast and the Midwest. Population density and landfill availability appear to be the major reasons for the prevalence of facilities in these regions.

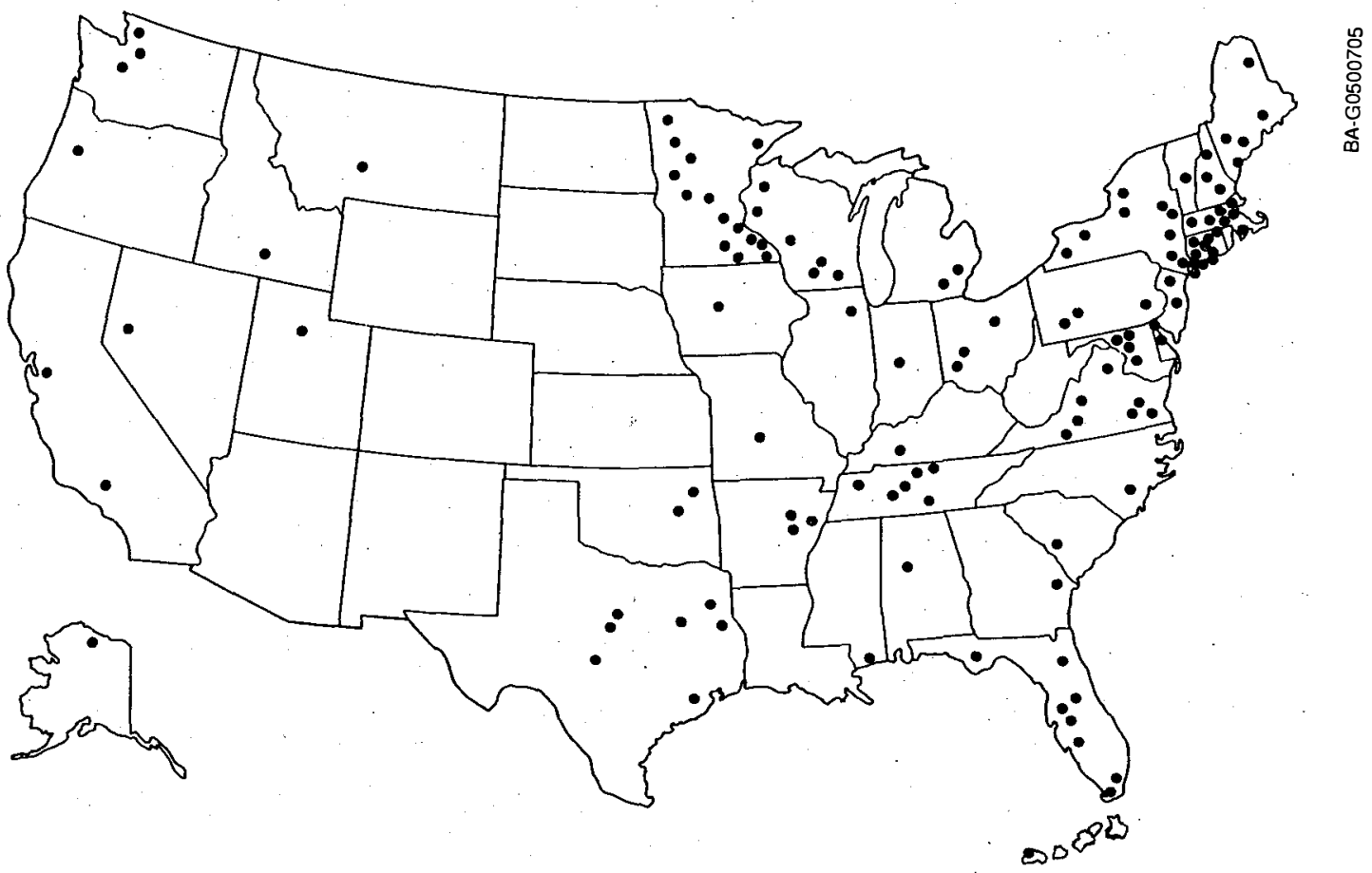

Figure 5-2. Location of existing waste-to-energy plants 
The majority of these systems are mass burn units, as shown in Table 5-2.

Table 5-2. Current Waste-to-Energy Processes for the United States

\begin{tabular}{lr} 
Type of Process & $\%$ \\
\hline & \\
Mass burn & 47.0 \\
Modular & 34.2 \\
Refuse-derived fuel & 17.8 \\
Other & 1.0
\end{tabular}

The distribution of existing and planned facilities is shown in Table 5-3. The West is somewhat behind other regions of the nation, but the number of planned facilities is increasing. The time frame in which the planned facilities will become operational depends somewhat on the outcome of pending EPA regulations (see Appendix E).

Table 5-3. Distribution of Waste-to-Energy Projects

\begin{tabular}{lcc}
\hline & $\%$ Existing & \% Planned \\
\hline Northeastern & 36.6 & 49.5 \\
Southern & 33.2 & 20.9 \\
North Central & 19.8 & 17.6 \\
West & 10.4 & 12.0 \\
\hline
\end{tabular}

The primary energy form for existing facilities is steam. However, as can be seen in Figure 5-3, the trend for planned facilities will be toward exclusive electricity generation. This trend can be explained by the fact that a number of past projects that sold steam to public or private customers encountered difficulties when the fuel buyers terminated or curtailed steam purchases. The sale of electricity involves less financial risk to project developers. Many developers, however, are still interested in selling steam because higher rates can generally be obtained from steam customers than electric utilities (especially in regions where "avoided-cost" of generating electricity is low).

The types of processes used in the western United States and their efficiencies are given in Table 5-4. The efficiency is defined as the actual capacity divided by the design capacity. Specific states where existing and planned facilities are located in the WRBEP area are given in Table 5-5. Table 5-6 gives details for each of these facilities including the start-up date, the size in tons per day, the type of system, the primary energy product, the cost received for sale of electricity (where applicable), and the capital cost. 


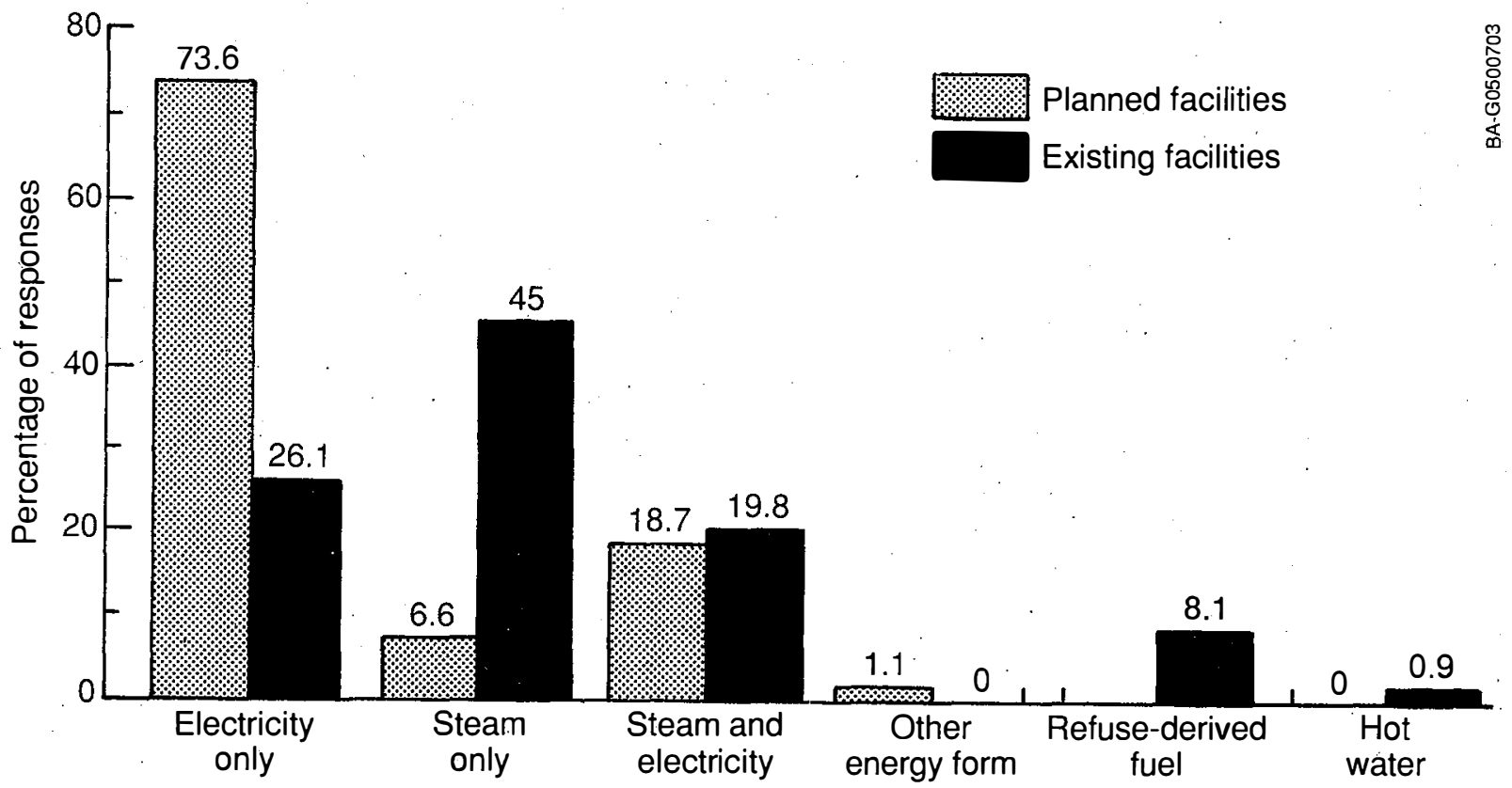

Figure 5-3. Primary energy form: planned and existing facilities

Table 5-4. Type of Process of Western Region

\begin{tabular}{lcc}
\hline Type of Process & $\%$ & Efficiency \\
\hline Mass Burn & 47.6 & 0.847 \\
Modular & 28.6 & 0.817 \\
Refuse-derived fuel & 23.8 & 0.825 \\
Other & 0 & \\
\hline
\end{tabular}

Table 5-5. Waste-to-Energy Facilities in Western Region

\begin{tabular}{lcc}
\hline State & Existing & Planned \\
\hline California & 2 & 4 \\
Nevada & 0 & 1 \\
Oklahoma & 2 & 0 \\
Texas & 7 & 3 \\
Utah & 1 & $\underline{0}$ \\
Total & $\mathbf{1 2}$ & $\mathbf{8}$ \\
\hline
\end{tabular}


Table 5-6. Existing/Planned Waste-to-Energy Facilities in the Western Region

$\begin{array}{lllllcc} & \text { Size } & & \text { Primary } & \text { Cost of Electricity } & \text { Capital Cost } \\ \text { Location } & \text { Date } & (\mathrm{(TPD} / \mathrm{kWh}) & \text { Type } & \text { Product } & (\$ \mathrm{M})\end{array}$

\begin{tabular}{|c|c|c|c|c|c|c|}
\hline Miami, OK & $11 / 82$ & 108 & Mod. & Steam & N/A & 3.56 \\
\hline Oklahoma City, OK & $9 / 86$ & 820 & RDF & Elec. & 4.20 & 32.00 \\
\hline Tulsa, OK & $3 / 86$ & 1125 & MB & Steam & N/A & 114.00 \\
\hline Austin, TX & $9 / 90$ & 800 & MB & Elec. & N/A & 70.00 \\
\hline Carthage, TX & $1 / 86$ & 40 & Mod. & Steam & N/A & 1.66 \\
\hline Center, TX & $8 / 86$ & 40 & Mod. & Steam & N/A & 1.87 \\
\hline Cleburne, TX & $3 / 86$ & 115 & Mod. & Elec. & 2.20 & 5.70 \\
\hline Gatesville, TX & $2 / 80$ & 13 & Mod. & Steam & N/A & 0.98 \\
\hline Lubbock, TX & $1 / 90$ & 425 & Mod. & Elec. & 3.92 & 21.10 \\
\hline Palestine, TX & $2 / 80$ & 25 & Mod. & Steam & N/A & 1.30 \\
\hline Texas City, TX & $12 / 90$ & 425 & Mod. & Elec. & 4.50 & 28.50 \\
\hline Waxahachie, TX & $6 / 82$ & 50 & Mod. & Steam & N/A & 2.64 \\
\hline Layton, UT & $1 / 88$ & 400 & MB & Steam & N/A & 40.00 \\
\hline Commerce, $\mathrm{CA}$ & $5 / 87$ & 400 & MB & Elec. & 8.70 & 35.48 \\
\hline Long Beach, CA & $8 / 88$ & 1380 & MB & Elec. & 8.10 & 102.00 \\
\hline Crows Landing, CA & $11 / 88$ & 800 & MB & Elec. & 8.00 & 85.18 \\
\hline San Bernadino, CA & $4 / 90$ & 1600 & MB & Elec. & 9.50 & 164.00 \\
\hline San Marcos, CA & $9 / 90$ & 2000 & RDF & Elec. & 6.20 & 217.00 \\
\hline Susanville, CA & $11 / 84$ & 100 & Mod. & $\mathrm{S} \& \mathrm{E}$ & 5.30 & 7.50 \\
\hline Reno, NV & $12 / 90$ & 1000 & RDF & $S \& E$ & 5.50 & 100.00 \\
\hline
\end{tabular}

\section{Legend}

TPD $=$ tons per day

$\mathrm{MB}=$ mass burn

Mod. = modular

RDF = refuse-derived fuel

Elec. $=$ electricity

$\mathrm{S} \& \mathrm{E}=$ steam and electricity 


\subsection{ENVIRONMENTAL ISSUES}

The EPA is currently developing air pollution emission rules for new and existing municipal waste combustion facilities pursuant to Section III of the Clean Air Act. These rules were proposed in November 1989, and promulgation is planned for December 1990. A paper providing information on EPA's technical activities related to this regulatory effort is included as Appendix E.

State-by-state current regulations are listed below.

Arizona. All incinerators must have two permits: an air quality permit and a solid waste permit. All incinerators must meet a particulate emissions standard of $0.1 \mathrm{gr} / \mathrm{dscf}$ (corrected to $12 \% \mathrm{CO}_{2}$ ) and a visual emissions standard of $20 \%$ opacity. For more information, call the Department of Environmental Quality, Air Quality Section in Phoenix at (602) 257-2277 and Solid Waste Section at (602) 257-6989.

California. Air quality is regulated by Air Quality Management Districts; regulations vary from district to district. All districts require permits to operate incinerators. Each district has particulate, visual, and air toxics emission standards. The air toxics emissions requirements depend greatly on the location of the facility and vary significantly from district to district. There are many other requirements. If the incinerator treats wastes generated offsite, it must have a permit from the State Health Services Department. For more information, call the California Department of Health Services, Hazardous Materials Management Section in Sacramento at (916) 324-9611.

Colorado. A permit is required for all incinerators. Particulate emissions may not exceed 0.1 gr/dscf (corrected to $12 \% \mathrm{CO}_{2}$ ). The visual emissions standard is $20 \%$ opacity. If offsite wastes are treated, a certificate of designation is required by the Solid Waste Management Department. Proposed regulations, which include air toxics emissions limits, will probably go into effect in late 1989 or early 1990. For more information, call the Department of Health, Air Pollution Control Division in Denver at (303) 331-8591.

Kansas. There are many solid waste processing requirements, including regulations on waste handling, storage, and ash disposal. Air quality regulations include particulate emissions standards that range from 0.10 to $0.30 \mathrm{gr} / \mathrm{dscf}$ (corrected to $12 \% \mathrm{CO}_{2}$ ) depending on the capacity of the incinerator. The visual emissions standard is $20 \%$ opacity. For more information, call the Department of Health and Environment, Solid Waste Management Section in Topeka at (913) 296-1590 and the Air Quality and Radiation Section at (916) 2961572.

Nebraska. Incinerators with capacities less than 1 ton/h may not emit particulate matter at a rate greater than $0.2 \mathrm{gr} / \mathrm{dscf}$ (corrected to $12 \% \mathrm{CO}_{2}$ ). Larger incinerators may not emit more than $0.1 \mathrm{gr} / \mathrm{dscf}$ (corrected to $12 \% \mathrm{CO}_{2}$ ). Visual emissions may not exceed $20 \%$ opacity. Incinerators must meet best available control technology (BACT) if they emit more than 2.5 ton/yr of any of 309 specified contaminants. Other requirements, including secondary temperature and retention time, are written into permits. These requirements are determined on a case-by-case basis. For more information, call the Department of Environmental Control, Air Quality Division in Lincoln at (402) 471-2189. 
Nevada. All incinerators must have a permit. The particulate emissions standard for incinerators with capacities less than $2000 \mathrm{lb} / \mathrm{h}$ is $3 \mathrm{lb} /$ ton dry charge. The allowable particulate emissions rate for larger incinerators, $\mathrm{e}(\mathrm{lb} / \mathrm{h})$, is determined by the formula

$$
e=\left(40.7 \times 10^{-5}\right) c
$$

where $c$ is the charge rate in pounds per hour. The visual emissions standard is $20 \%$ opacity. The secondary chamber temperature must be at least $1400 \%$ with a residence time of $0.3 \mathrm{~s}$. There are also air toxics emissions limits. A county commission permit is required and is often difficult to obtain. For more information, call the Department of Conservation and Natural Resources, Division of Environmental Protection in Carson City at (702) 885-5065.

New Mexico. A permit is required for incinerators that emit any criteria pollutant at a rate greater than $10 \mathrm{lb} / \mathrm{h}$ for controlled emissions and greater than $100 \mathrm{lb} / \mathrm{h}$ for uncontrolled emissions. Visual emissions may not exceed $20 \%$ opacity. Registration of air toxics emitted above certain levels is required. Other requirements are determined on a case-by-case basis and specified in the permits. For more information, call the Health and Environment Department, Air Quality Bureau in Santa Fe at (505) 827-0070.

North Dakota. Incinerators must have a permit. The allowable particulate emission rate, $e$, is determined by the formula

$$
e=0.00515\left(R^{0.9}\right)
$$

where $R$ is the refuse burning rate in $\mathrm{lb} / \mathrm{h}$. Visual emissions may not exceed $20 \%$ opacity. The regulations state that the secondary chamber temperature must be at least $1500 \%$ with a retention time of $0.3 \mathrm{~s}$. However, more stringent requirements are usually written into permits. A minimum secondary chamber temperature of $1800 \mathrm{~F}$ and a retention time of $1 \mathrm{~s}$ are usually specified. There are no restrictions on air toxics emissions. For more information, call the Department of Health, Air Quality Management Branch in Bismarck at (701) 2242348.

Oklahoma. Permits are required for all incinerators. Incinerators must be of multiple chamber design with a primary chamber temperature of at least $800 \%$. The particulate emissions standards vary depending on the charge rate. Visual emissions may not exceed $20 \%$ opacity for more than $5 \mathrm{~min}$ in $1 \mathrm{~h}$ and not more than $20 \mathrm{~min}$ in $24 \mathrm{~h}$. For more information, call the Department of Air Quality Service in Oklahoma City at (405) 271-5220.

South Dakota. Permits are required for incinerators with capacities larger than $100 \mathrm{lb} / \mathrm{h}$. The particulate standard for incinerators with capacity greater than or equal to 50 ton/day is 0.18 $\mathrm{gr} / \mathrm{dscm}$ (corrected to $12 \% \mathrm{CO}_{2}$ ). There is no particulate emissions standard for smaller incinerators. Visual emissions may not exceed $20 \%$ opacity. For more information call the Department of Water and Natural Resources, Office of Air Quality and Solid Waste in Pierre at (605) 773-3153.

Texas. Incinerators must be of dual chamber design with a secondary chamber temperature of at least $1800 \%$ and a retention time of $1 \mathrm{~s}$. The visual emissions standard is $20 \%$ opacity. If hydrogen chloride emissions exceed $4 \mathrm{lb} / \mathrm{h}$, the incinerator must be equipped with a 
scrubber. Other requirements, including air toxics emissions limits, are determined on a caseby-case basis and specified in the permits. For more information, call the Air Pollution Control Board, Combustion Section in Austin at (515) 451-5711.

Utah. All new air pollution sources must have a permit. All sources must meet BACT. Requirements, including air toxics emissions limits, secondary chamber temperature and retention time, and particulate standards, are determined on a case-by-case basis and specified in the permits. For more information, call the Department of Health, Bureau of Air Quality in Salt Lake City at (801) 538-6108.

Wyoming. A permit is required for all incinerators. Two-stage combustion is required. Incinerators must meet BACT. The particulate emissions standard is $0.2 \mathrm{lb} / 100.0 \mathrm{lb}$ refuse charged. Visual emissions may not exceed $20 \%$ opacity. For more information, call the Department of Environmental Quality, Air Quality Division, in Cheyenne at (307) 777-7391.

Types of pollution control for planned and existing facilities are given in Table 6-1. The baghouse or fabric filter and dry scrubbers are typically used in combination. Indications are that future wasteto-energy facilities will employ more sophisticated air pollution control equipment than current facilities. The combination of scrubbers and baghouse filters can remove both acid gases (i.e., $\mathrm{HCl}$ ) and particulates from stack gases; electrostatic precipitators generally remove only particulates. More stringent air pollution control standards will dictate that advanced technologies be employed in most regions of the country.

Ash disposal legislation from waste-to-energy facilities remains controversial. Table 6-2 shows the percent of ash residue generated based on the weight of incoming MSW for various systems. The average produced per facility is 166.12 tons per day, with the daily U.S. generation being 31,396 tons.

Table 6-1. Pollution Control Equipment

\begin{tabular}{lr}
\hline Type & $\%$ \\
\hline & $\%$ \\
Baghouse or fabric filter & 28.3 \\
Dry scrubbers & 29.6 \\
Electrostatic precipitators (ESP) & 26.4 \\
After-burn systems & 8.0 \\
Other & 5.7 \\
Nothing & 1.9 \\
\hline
\end{tabular}


Table 6-2. Ash Production

\begin{tabular}{lr}
\hline Process & $\begin{array}{r}\% \text { of } \\
\text { Capacity }\end{array}$ \\
\hline Modular & 26.9 \\
Mass Burn & 23.7 \\
Refuse-derived fuel & 13.7 \\
Average & $\underline{23.5}$ \\
& \\
& $(166.12$ TPD) \\
\hline
\end{tabular}




\subsection{TRENDS}

The increased development of waste-to-energy facilities is closely related to the solid waste disposal crisis. The public's perception of solid waste issues has changed in recent years, with the "garbage barge" as a tangible example of the mounting problem. Although environmental concerns are associated with solid waste disposal, many political leaders are recognizing the need for alternatives to landfills. Recycling efforts have increased in many communities, but these alone are not sufficient to alleviate the landfill shortages.

More than 100 waste-to-energy facilities are now operating and 18 more are scheduled to come on line during the next five years, indicating continued growth of the industry. Relatively few projects exist or are being planned in the western United States.

A shift in technologies from modular units to larger mass-burn systems is occurring; however, a decrease in the design capacity has been seen since 1986. The movement in energy production is toward electric power generation and away from steam. A total of $1252 \mathrm{MW}$ of electric power (gross) is generated by existing waste-to-energy plants. An additional $3805 \mathrm{MW}$ will be available if all planned projects are built in the United States.

Table 7-1 shows the time range required to complete various activities associated with waste-to-energy . projects and emphasizes the need to plan systems prior to landfill closures.

Table 7-1. Timing of the Waste-To-Energy Project Development Process

\begin{tabular}{lc}
\hline \multicolumn{1}{c}{ Activity } & $\begin{array}{l}\text { Time Range Required } \\
\text { to Complete Activity }\end{array}$ \\
\hline $\begin{array}{l}\text { Perceive landfill problem; perform } \\
\text { feasibility study of alternative MSW } \\
\text { disposal methods; assess resource } \\
\text { recovery markets }\end{array}$ & $1-4$ years \\
$\begin{array}{l}\text { Project design; issue bids; } \\
\text { negotiate markets }\end{array}$ & $1-4$ years \\
$\begin{array}{l}\text { Select and negotiate contracts } \\
\text { with contractor(s); obtain permits } \\
\text { begin construction }\end{array}$ & $1-4$ years \\
$\begin{array}{l}\text { Project shakedown and acceptance } \\
\text { begin operations }\end{array}$ & $1-3$ years \\
\multicolumn{1}{c}{ Total } & $4-15$ years \\
\hline
\end{tabular}


Appendix A

Ad Hoc Committee Contacts 


\section{Arizona}

Mr. Ray Williamson

Solar Energy Manager

Arizona Energy Office

$1700 \mathrm{~W}$. Washington

Phoenix, AZ 85007

(602) $542-3682$

\section{California}

Ms. Nancy Deller

Chief, Development Division

California Energy Commission

1615 9th Street

Sacramento, CA 95814

(916) 324-3517

\section{Colorado}

Ms. Sue Grizwold

Colorado Office of Energy Conservation

112 E. 14th Avenue

Denver, CO 80203

(303) 894-2144

Kansas

Dr. Richard Hayter

Director, Kansas Extension Service

Engineering Extension Program

Ward Hall Room 133

Kansas State University

Manhattan, KS 66506

(913) 532-6026

\section{Nebraska}

Mr. Larry Pearce

Assistant Director for Planning and Research

Nebraska Energy Office

State Capitol Building

14th \& Lincoln Mall

P. O. Box 95085

Lincoln, NE 68509-5085

(402) 471-2867
Nevada

Mr. Dave McNeil

Energy Program Specialist

Office of Community Services

Capitol Complex

1100 E. William Street

Carson City, NV 89710

(702) 885-4909

New Mexico

Rudi Schoenmaker

Southwest Technology Institute

Las Cruces, NM

(505) 646-1846

\section{North Dakota}

Ms. Shirley Dykshoorn

Director, Office of Intergovernmental

Assistance

State Capitol, 14th Floor

Bismarck, ND 58505

(701) 224-2094

\section{Oklahoma}

Ms. Ellen Bussert

Director of Programs

Office of the Governor

212 State Capitol

Oklahoma City, OK 73105

(405) 521-2342

\section{South Dakota}

Mr. Steve Wegman

South Dakota Energy Office

2171/2 West Missouri

Pierre, SD 57501

(605)773-3603 
Texas

Ms. Judith Carroll

Office of Budget and Planning

Energy Management Center

201 East 14th

P. O. Box 12428

Capitol Station

Austin, TX 78711

(512) 463-1871

\section{Utah}

Mr. Tom Turner

Utah Energy Office

3 Triad Center, Suite 450

355 West North Temple

Salt Lake City, UT 84180-1240

(801) 538-5428

\section{Wyoming}

Dr. Dale Hoffman

Econ. Develop. and Stabilization Bd.

122 W. 25th Street

Herschler Building

Cheyenne, WY 82002

(307) 777-7284 
Appendix B

\section{Government Agencies}

Involved With

Waste to Energy 
SEPI

\section{FEDERAL GOVERNMENT}

\section{U.S. Department of Commerce}

National Bureau of Standards

Chemistry Bldg. B348

Gaithersburg, MD 20899

Dr. Eugene S. Domalski

(301) $975-2588$

\section{U.S. Department of Energy}

Office of Conservation and Renewable Energy

Biofuels and Municipal Waste Technology

Division

Forrestal Building

1000 Independence Avenue, SW

Washington, DC 20585

Donald K. Walter

(202) 586-6750

\section{U.S. Department of the Interior}

Environmental Technology

Recycling Research

240 E Street, NW

Washington, DC 20241

Roger DeCesare

(202) 634-1237

\section{U.S. Environmental Protection Agency}

Office of Solid Waste

401 M Street, SW

Washington, DC 20460

Siva Garg, Environmental Engineer, Combustion Program

(202) 382-7937

\section{U.S. House of Representatives}

House Committee on Energy and Commerce Subcommittee on Energy and Power Rayburn House Office Building Washington, DC 20510

Philip Sharp, Chairman

(202) 226-2500

\section{U.S. House of Representatives}

House Committee on Science, Space, and Technology

Subcommittee on Energy Research and Development

Rayburn House Office Building

Washington, DC 20515

Marilyn Lloyd, Chairman

(202) 225-8056 


\section{STATE GOVERNMENT}

Arizona

Arizona Department of Environmental Quality Waste Program Planning Section 2115 N. Central Avenue

Phoenix, AZ 85004

Stephanie R. Wilson, Manager

(602) 257-2317

Arizona Energy Office

Department of Commerce

State Capitol, 5th Floor

$1700 \mathrm{~W}$. Washington

Phoenix, AZ 85007

Mark Ginsberg

(602) 255-3632

\section{California}

California Energy Commission

Energy Facilities Siting and

Environmental Division

1516 9th Street, MS 16

Sacramento, CA 95814

Lorraine Van Kekerix

(916) 324-3213

California Energy Commission

Energy Technology Development Division

1516 9th Street, MS 43

Sacramento, CA 95814

David L. Modisette, Chief

(916) 324-3517

George Simons

(916) 324-3553

California Waste Management Board 1020 9th Street, Suite 300

Sacramento, CA 95814

Herb Iwahiro, Chief Deputy

Executive Officer

(916) 322-6329

\section{Colorado}

Colorado Department of Agriculture

Resource Analysis Section

1525 Sherman Street

Denver, CO 80203

Dr. David Carlson

(303) 866-3219

Colorado Department of Health

Waste Management Division

4210 East 11th Avenue

Denver, CO 80220

David C. Shelton

(303) 320-8333

Colorado Office of Energy Conservation

112 East 14th Avenue

Denver, CO 80203

Janet Hartsfield, Assistant Director

(303) 894-2144

\section{Kansas}

Kansas Department of Health and Environment

Solid Waste Management Section

Building 740, Forbes Field

Topeka, KS 66620

Charles H. Linn, Chief

(913) 862-9360

\section{Nebraska}

Nebraska Department of Environmental Control

Water and Waste Management Division

P. O. Box 904877

Lincoln, NE 68509

Bruce Baugh, Section Supervisor of Waste Recovery

(402) 471-4219 
Nebraska, continued

Nebraska Energy Office

State Capitol

Lincoln, NE 68509

Larry Pearce

(402) 471-2867

Nevada

Nevada Department of Conservation and

Natural Resources

Division of Environmental Protection

Waste Management Program

Capitol Complex

Carson City, NV 89710

Verne Rosse

(702) 885-5872

\section{New Mexico}

New Mexico Health and Environment Department

Solid Waste Section

Harold Runnels Building

P. O. Box 968-1190, St. Francis Drive

Santa Fe, NM 87504-0968

Raymond R. Sisneros, Program Manager (505) 827-2775

North Dakota

North Dakota Department of Health

Division of Hazardous Waste Management and Special Studies

1200 Missouri Avenue

P. O. Box 5520

Bismark, ND 58502

Martin R. Schock, Director

(701) 224-2366

North Dakota Office of Intergovernmental Assistance 14th Floor

State Capitol Building

Bismark, ND 58508

\section{Oklahoma}

Oklahoma Department of Health

Waste Management Service

Solid Waste Division

P. O. Box 53551

1000 Northeast 10th Street

Oklahoma City, OK 73152

R. Fenton Rood, Director

(405) 271-7169

\section{South Dakota}

South Dakota Department of Water and Natural Resources of Air and Waste

Foss Building

Pierre, SD 57501

Joel C. Smith, Administrator

(605) 773-3329

South Dakota Office of Energy Policy

State Capitol

Pierre, SD 57501

Clint Roberts, Director

(605) 773-3603

Texas

Texas Department of Health

Division of Solid Waste Management 1100 West 49th Street

Austin, TX 78756

Hector H. Mentieta, P.E., Director

(512) 458-7271

Utah

Utah Department of Health

Bureau of Solid and Hazardous Waste

288 North 1460 West

Salt Lake City, UT 84116

Brent C. Bradford, Director

(801) $538-6170$ 
Wyoming

Wyoming Department of Environmental Quality

Solid Waste Management Program 122 West 25th Street

Cheyenne, WY 82002

David A. Finley, Program Manager

(307) 777-7752 


\section{Appendix C}

\section{System Vendors/Operators:}

and

\section{Equipment Manufacturers}


Accutech Environmental Services, Inc. 100 Highway 35

Keyport, NJ 07735

Harry J. Moscatello, President

(201) 739-6444

\section{American Baler Company}

Hickory Street

Bellevue, OH 44811

J. B. Russell, Vice President, General Sales Manager

(419) 483-5790

American Recycling Corporation

2501 Lynnwood Drive, \#105

Arlington, TX 76013

Francis A. Swartz, President

(817) 265-4764

American Ref-Fuel Company

757 N. Eldridge (77079)

P. O. Box 3151

Houston, TX 77253

Ed Joran, Vice President

(713) 584-4504

American Resource Recovery

600 Larry Court

Waukesha, WI 53186

Dan Warren, Vice President

(414) 784-9200

Atlas Systems Corporation

East 6416 Main Avenue

P.O. Box 11496

Spokane, WA 99211

W. B. Hickman, P.E.,

Executive Vice President

(509) 535-7775

Babcock \& Wilcox Company

Power Generation Group

1990 North California Blvd., Suite 400

Walnut Creek, CA 94596

J. C. Wilcox, Jr.

(415) $947-1100$
Basic Environmental Engineering, Inc.

21 West 161 Hill Avenue

Glen Ellyn, IL 60137

John N. Basic, Sr., President

(312) 469-5340

Belco Pollution Control Corp.

8 Peach Tree Hill Rd.

Livingston, NJ 07039

Eugene Lempicki

(201) 535-2500

Bepex Corp.

333 NE Taft St.

Minneapolis, MN 55413

Ralph Weggel

(612) 331-4370

Black \& Veatch, Inc.

P. O. Box K228

Richmond, VA 23288

Hunter Taylor

(804) 288-6767

Blount Energy Resource Corp.

P.O. Box 4577

4520 Executive Park Drive

Montgomery, AL 36195

Thomas M. James, Vice President

(205) 244-5484

Bogot Brothers, Inc. 13700 Red Arrow Hwy. Harbert, MI 49115-0026

Donald L. Buckle, President

(616) 469-5500

Brule, C.E. \& E., Inc.

13920 South Western Avenue

P.O. Box 35

Blue Island, IL 60406

James Friedrich

(312) 388-7900 
Buhler-Miag, Inc.

P. O. Box 9497

1100 Xenium Lane

Minneapolis, MN 55440-9497

Daniel J. Kenna, Sales Manager

(612) $545-1401$

\section{Burn-Zol}

P. O. Box 266, Elm Road Station

Mountain Lakes, NJ 07046

Edward Abendschein

(201) 299-7622

\section{C-E Environmental Systems}

Combustion Engineering; Inc.

31 Inverness Center Parkway

Birmingham, AL 35243

Jim Wilmoth, Director,

Business Development

(205) 991-2832

\section{C-E Power Systems}

Combustion Engineering, Inc.

1000 Prospect Hill Road

Windsor, CT 06095

Thomas Regan, Director, Marketing

(203) 285-5122

\section{C-E Resource Recovery Systems}

Combustion Engineering, Inc.

7 Waterside Crossing

Windsor, CT 06095-0500

Noel D. Hazzard, Director,

Marketing Services

(203) 285-9924

C-E Raymond

Combustion Engineering, Inc.

650 Warrenville Road

Lisle, IL 60532

Richard J. Grzelak, Vice President

Sales and Marketing

(312) $971-2500$
CMI Energy Conversion System, Inc.

520 Colcord Drive

Oklahoma City, OK 73102

Robert T. Helm

(405) 235-2224

Cadence Chemical Resource, Inc.

Hazardous Waste to Energy

Recycling Dept.

One Marine Drive

Michigan City, IN 46360

Theodore J. Reese, President

(219) 879-0371

Cadoux, Inc.

2010 Exeter Road

Germantown, TN 38138

Gerard Holbach

(901) 754-0676

California Pellet Mill Company

101 Howard, Suite 2A

P.O. Box 6806

San Francisco, CA 94101

Robert D. MacDaniel

(415) 431-3800

Cambrian Energy Systems

2401 Colorado Avenue, Suite 270

Santa Monica, CA 91030

Tudor Williams

Bob Hatch

(213) 725-1139

Carthage Machine Company

571 West End Avenue

Carthage, NY 13619

Charles G. Astafan

(315) 493-2380

Clark-Kenith, Incorporated

7500 Old Georgetown Road, 15th Floor

Bethesda, MD 20814

W. Dennis Carroll, President \& Chief.

Executive Officer

(301) 657-7215 
Clear Air, Inc. clo Ralph W. Taylor

811 102nd Avenue, North

Naples, FL 33963

R. W. Taylor

(813) 598-9595

Combustion Power Co.

1020 Marsh Rd., \#100

Menlo Park, CA 94025

Robert Vander Molen

(415) 324-4744

Combustion Technologies, Inc.

1104 East Big Beaver Road

Troy, MI 48083

Irving M. Williams,

Vice President/

Marketing and Sales

(313) 524-2007

Consumat Systems, Inc.

P. O. Box 9379

Richmond, VA 23227

Carroll T. Hughes, Jr.

(804) 746-4120

Continental Power Systems

7730 E. Belleview, \#200

Englewood, CO 80111

Tom Laurance, President

(303) 770-6766

Deltak Corporation

P. O. Box 9496

Minneapolis, MN 55440

Robert Brown, Vice President, Sales and Marketing

(612) 544-3371

Dennison Manufacturing Company

300 Howard Street

Framingham, MA 01701

John C. Rudisill, Plant Manager

(508) 879-0511
M. H. Detrick Co.

19444 S. 97th Avenue

Mokena, IL 60448

Lloyd Bly, Vice President, Sales

(312) 479-5085

Detroit Stoker Company

1510 East First Street

Monroe, MI 48161

E. A. Taylor, Vice President, Sales

(313) $241-9500$

Dynatech Scientific, Inc.

99 Erie Street

Cambridge, MA 02139

John C. Harding, President

(617) $868-8050$

Dynecology, Incorporated

611 Harrison Avenue

Harrison, NY 10528

Helmut Schulz, CEO

(914) $967-8674$

Ecolaire Combustion Products, Inc.

P. O. Box 240707

Charlotte, NC 28224

Robert Merdes

(704) $588-1620$

Elliott Company

North Fourth Street

Jeannette, PA 15644

Alan R. Vitalis, Manager,

Turbine Marketing

(412) 527-8369

Enercan Resources Corp.

403 Balleyfield Drive

Mississauga, Ontario L5A IL2

Canada

A. H. Bradley, President

(716) 834-4410 
Enercon Systems, Inc.

300 Huron St.

Elyria, $\mathrm{OH} 44035$

David A. Hoecke, President

(216) 323-7080

Energy Answers Corporation

79 North Pearl Street

Albany, NY 12207

Patrick F. Mahoney, President

(518) 434-1227

Energy Development Industries

1747 Detroit Court, NW

Atlanta, GA 30314

L. Edward Price, President

(404) 792-3835

Foster Wheeler Power Systems, Inc.

Perryville Corporate Park

Clinton, NJ 08809

R. J. Sift, President

(201) $730-5228$

GSF Energy, Inc.

O. Box 1900

Long Beach, CA 90801

Kathleen Flanagan, Manager,

Public Affairs

(213) 595-4964

General Electric Co.

One River Road

Building 2, Room 753

Schenectady, NY 12345

(518) 385-0972

Harbert/Triga Resource Recovery

One Chase Corporate Center

P. O. Box 1297

Birmingham, AL 35201

Lawrence G. Michalove

(205) 985-5454
Heil Engineered Systems

2000 West Montana

Milwaukee, WI 53215

Don Kaminski, General Manager

(414) 647-3439

Henley Burrowes Waste Management

9181 Interline Ave.

Baton Rouge, LA 70809

Herbert J. Boxill

(504) 923-3525

Herman Bogot and Company

3143 Nottingham Avenue

Chicago, IL 60634

Scott Bogot

(312) 637-6037

Industrial and Municipal Engineering

P. O. Box N

Galva, IL 61434

LaVerne Charlet, Sr. Vice President

(309) 932-2036

(800) 447-5684 (outside IL)

(800) $322-5661$ (IL only)

Industronics, Inc.

489 Sullivan Avenue

South Windsor, CT 06074

Barbara C. Klenke, Reg. Sales Mgr.

(203) 289-1588

International Incinerators Incorporated 506 Coolidge Ave.

P. O. Box 1828

Columbus, GA 31902

Ronald D. Hale

(404) 327-5475

John Zink Company

Comtro Division

4401 South Peoria Avenue

P. O. Box 702220

Tulsa, OK 74170

Roger Etter

(918) 744-4349 
Joy Technologies, Inc.

Western Precipitation Division

404 East Huntington Drive

Monrovia, CA 91016-3633

Robert C. Hyde

(818) 301-1100

Katy-Seghers, Inc.

3844 Walsh Street

St. Louis, MO 63116

Art Beckman

(314) $752-2400$

Keeler/Dorr-Oliver Boiler Co.

Manufacturers of Keeler Water Tube

Boilers, Faber Combustion Systems

238 West Street

Williamsport, PA 17701

-Max Wahler, Program Manager

(717) 326-3361

Laidlaw Gas Recovery Systems

39899 Balentine Drive, Suite 275

Newark, CA 94560

Kenneth Wuest, President

(415) 656-8327

Laurent Bouillet-Howard

2700 N. Central Ave.

Suite LL100

Phoenix, AZ 85004

James L. Grant, Manager of

Business Development

(602) 222-5999

Lundell Manufacturing Co., Inc.

Hwy 3

Cherokee, IA 51012

Steve Paulsen, Vice President

(800) 831-4841

Pan Am Building, Suite 303 East

200 Park Ave.

New York, NY 10166

(212) $986-2515$
Maxon Industries, Inc.

5750 South Eastern Avenue

City of Commerce, CA 90040

John Tidwell, Vice President,

Finance

(213) $752-0200$

McClain Industries, Inc.

P. O. Box M

Utica, MI 48087

James McManus

(313) 264-3611

Mechanical Technology, Inc.

968 Albany-Shaker Road

Latham, NY 12110

Frank S. Ralbovsky, Product Manager

(518) 785-2211

Methane Development Corp.

Telport 1, One Teleport Drive

Staten Island, NY 10311

Zain Mirza

(718) $983-2290$

Montenay Power Corp.

300 Old County Rd.

Mineola, NY 11501

Steve Passage

(516) $742-6300$

Morse-Boulger, Inc.

127-36 Northern Blvd.

Flushing, NY 11368

Matthew Gaskin, Vice President

(718) 672-2100

Nashville Thermal Transfer Corp.

110 First Avenue, South

Nashville, TN 37201

J. T. Hestle, P.E., General Manager

(615) 244-3150

National Ecology, Inc.

16 Greenmeadow Drive

Timonium, MD 21093

Charles A. Simms, President

(301) 252-5666 
Natkin and Company

440 Patterson Park Rd.

Ashland, VA 23005

Charley Gilbert

(804) 798-4773

Newell Industries

P.O. Box 10629

San Antonio, TX 78210

Scott Newell, III

(512) 227-9090

Nicholson Manufacturing Company

3670 East Marginal Way South

Seattle, WA 98134

William Iverson, General Manager

(206) 682-2752

Northwest Iron Fireman, Inc.

1508 5th Ave. North

P. O. Box 1068

Fargo, ND 58107

Cliff Jacobs, President

(701) 237-4096

O'Brien Energy Systems

225 S. 8th Street

Philadelphia, PA 19106

Doug Nielsen

(215) 627-5500

O'Connor Combustor Cor.

A Westinghouse Subsidiary

100 Kalmus Drive

Costa Mesa, CA 92626

William G. Honsaker, Sales Manager

(714) 979-9691

(213) 629-1455

Ogden Martin System, Inc.

40 Lane Road

Fairfield, NJ 07007-2615

Gloria A Mills, Senior Vice President (201) 882-7179
Orfa Corp. of America

51 Haddonfield Rd.

Suite 325

Cherry Hill, NJ 08002

Christine Sullivan, Director of

Public Relations

(609) 662-6600

Ormat Energy Systems, Inc.

610 E. Glendale Ave.

Sparks, NV 89431

Daniel N. Schochet, Vice President

Douglas M. Miller,

Project Development Manager

(702) 356-9111

Pacific Waste Management Corp.

326 East Colorado Blvd., Suite 252

Pasadena, CA 91101-2204

Mark White

(818) 793-7526

Price Industries, Inc.

PIET Building

9816 Frankstown Road

Pittsburgh, PA 15235

Richard C. Price, President - C.E.O.

James Peduzzi, Production Manager (412) 242-0700

Problem Waste Incinerations, Inc. 98 East East Saddle River Road

Saddle River, NJ 07458

Charles A. Pazer

(201) 327-5598

Rader Companies, Inc.

P. O. Box 20128

Portland, OR 97220

Gary Kroeker

(503) 255-5330

Raytheon Service Company

2 Wayside Road

Burlington, MA 01803

Richard Nickerson

(508) 272-9300 
Research-Cotrell

Custodis Environmental Division

P. O. Box 1500

Somerville, NJ 08876

Prakash Dhargalkar

(201) 685-4000

Resource Conversion Systems, Inc. 11511 Katy Freeway, Suite 500

Houston, TX 77079

Henry O. Hefty, Vice President

(713) 531-9229

Resource Technology Corp.

200 Milton Street

P. O. Box 506

Dedham, MA 02026

Brian R. Hogan

(617) 329-3900

Reuter, Inc.

410 11th Avenue

Hopkins, MN 55343

Edward J. Reuter

(612) 935-6921

\section{Rexnord}

4701 West Greenfield Avenue

P. O. Box 2022

Milwaukee, WI 53201

Henry Lisiecki, Industry Manager

(414) 643-2342

Reynolds Aluminum Recycling Co.

Solid Waste Recovery Systems

6601 West Broad Street

Richmond, VA 23230

G. P. Sackett, Business Manager

Riley Energy Systems Corp.

5 Neponset Street

P. O. Box 187

Worcester, MA 01613-0187

Joseph Langone

(508) 852-7100
Riley Stoker Corp.

5 Neponset St.

P. O. Box 15040

Worcester, MA 01615-0040

Harry Culberson

(508) 852-7100

SPM Group, Inc.

Hwy. 16 \& 52 North

Preston, MN 55965

Konrad Ruckstuhl, Chairman

(507) 765-2126/2107

Saturn Shredders, Division of Mac Corp.

201 East Shady Grove Road

Grand Prairie, TX 75050

Jack West, Executive Vice President

(214) $790-7800$

Sigoure Development Co.

2201 Wisconsin Ave., NW

Washington, DC 20007

Jim Lexo

(202) 337-2335

Simonds Manufacturing Corp.

304 Progress Road

Auburndale, FL 33823

J.C. Presley

(813) 967-8566

F. I. Smidth

300 Knickerbocker $\mathrm{Rd}$.

Cresskill, NJ 07626

Daniel Lisiecki

(201) 871-3300

Sprout Waldren

Division of Koopers Company

802 Logan Street

Muncy, PA 17756

Gary Staggs

(717) $546-8211$ 
Standard Oil Engineered Materials Co.

Refractories Division

Refactories Product Plant

P. O. Box 187

Keasbey, NJ 08832

Stanley Gurskey

(201) 738-4600

Synergy Systems Corp.

1 World Trade Center, \#3000

New York, NY 10043

Ron Spangler, President

(212) 432-5191

Technochem Environmental Systems, Inc.

700 Plaza Drive

Secaucus, NJ 07094

Eric Mayer, President

(201) 330-9300

Thermal Reduction Co., Inc.

1524 Slater Rd.

Bellingham, WA 98226

Frank Zurline

(206) 676-0660

Thermo Electron Corp.

Energy Systems Division

101A First Ave.

P. O. Box 9047

Waltham, MA 02254-9047

Roger Michalowski, Sales Manager

Lazaros J. Lazaridis, Vice President, Marketing

(617) 622-1500

Trans Energy Systems

14711 Northeast 29th Place, Suite 101

Bellevue, WA 98007

Ronald J. Stryer, Director, Marketing and Applications Engineering

(206) $881-8500$
Tricil Recovery Services, Inc.

Bartow Municipal Airport

Route 3, Box 249

Bartow, FL 33830

Daniel Vivolo

(813) 533-9247

Triple/S Dynamics

1031 S. Haskell Ave.

Dallas, TX 75223

J. F. Sullivan, President

(214) $828-8600$

(800) $527-2116$

United Bio-Fuel Industries, Inc.

1925 Puddledock Rd.

Petersburg, VA 23803

Francis B. Richerson, Vice President

Engineering

(703) 733-5038

United McGill Corporation

2400 Fairwood Ave.

P. O. Box 820

Columbus, OH 43216

Ed Brabham

(614) 443-0192

VGT-DYKO Refractories Co.

8060 Montgomery Rd., Suite 301

Cincinnati, OH 45236

Charles L. Harris, Industrial Sales

Manager

(513) 793-6553

Valorga

4000 Tunlaw Rd., NW, Suite 223

Washington, DC 20007

B. Chatel

(202) 333-6151

Van Beek, Inc., Bio-Mass Energy

1433 N. Main

Sioux Center, IA 51250

Rallyn Van Beek

(712) 722-3709

Norlyn Van Beek 
Vicon Recovery Systems, Inc.

P. O. Box 700

Butler Center

Butler, NJ 07405

Joseph J. Domas, Jr., President

(201) 492-1776

Volund USA, Ltd.

900 Jorie Blvd., Suite 222

Oak Brook, IL 60521

Finn Moller-Nielsen

(312) 990-1480

Von Roll

25 Commerce Drive

Cranford, NJ 07016

Rolf Baumgartner

(201) 272-1555

W.E.R.E. International, Inc.

3002 Winegarden Dr.

Burlington, IA 52601

Harold Massner

(319) 752-0289

WTE Corporation

7 Alfred Circle

Bedford, MA 01730

David B. Spencer, President

(617) $275-6400$

Waste Energy, Inc.

Rt. 6

Box 464

Morresville, NC 28115

Gene Adams

(704) 664-9407

Waste Management Energy Systems, Inc. 3550 W. Busch Blvd., Suite 295

Tampa, FL 33618

H.T.D. Sjoberg

(813) 931-0500

Wayne Engineering Corp.

P. O. Box 648

Cedar Falls, IA 0613

Robert L. Robinson

(310) 266-1721
Westinghouse Electric Corp.

Combustion Control Division

P. O. Box 901

Orrville, $\mathrm{OH} 44667$

J. W. Worthington, Product Line

Westinghouse Electric Corp.

Resource Energy Systems Division

2400 Ardmore Blvd., Cost Building

Pittsburgh, PA 15221

Fred S. Pollier, Manager RESD Division

Sales

(412) 636-5910

Wheelabrator Environmental Systems, Inc.

55 Ferncroft Road

Danvers, MA 01923

Kevin Stickney

(508) 777-2207

Williams Patent Crusher and Pulverizer Company

2701 North Broadway

St. Louis, MO 63102

Carl Rehmer, Sales Manager

(314) 621-3348

York-Shipley Division of Donlee

Technologies, Inc.

693 North Hills Road

P. O. Box 349

York, PA 17405

M. E. Gilligan, Jr., Senior Vice President

(717) $755-1081$

Zimpro/Passavant, Inc.

301 W. Military Road

Rothschild, WI 54474

James M. Force, Communications

(715) 359-7211

Zurn Industries, Inc.

1422 East Ave.

Erie, PA 16503-1592

Robert Esser, Mgr. Sales \& Marketing

(814) 452-6421 


\section{Appendix D \\ Engineering, Management, and} Technical Consultants 
A. V. Colabella, Engineers

138 Farnsworth Avenue

P. O. Box 187

Bordentown, NJ 08505-0187

Alfred V. Colabella, Jr.

(609) 298-7000

Ackenheil \& Associates Geo Systems, Inc. 1000 Banksville Road

Pittsburgh, PA 15216

A. C. Ackenheil

(412) 531-7111

Ron Albrecht Associates, Inc.

111 Chinquapin Round Road

P. O. Box 6352

Annapolis, MD 21401-0352

Ron Albrecht, President

(301) 269-0147

Alley, Young and Baugarter

P. O. Box 2036

Brentwood, TN 37024

E. Roberts Alley, President

(615) 373-1560

Anderson Geotechnical Consultants, Inc.

631 Commerce Drive

Roseville, CA 95678

Gery F. Anderson

(916) 786-8883

Andrews Environmental Engineering

1320 S. Fifth St.

Springfield, IL 62703

Douglas Andrews

(217) 528-1545

Armstrong Consultants, Inc.

861 Rood Avenue

Grand Junction, CO 81501

Edward A. Armstrong, President

(303) 242-0101

Arthur Beard Engineers, Inc.

144 Church Street, NW

Vienna, VA 22180

Jeffrey L. Van Atten

(703) $255-2470$
Aqua Tech, Inc.

140 South Park Street

Port Washington, WI 53074

David Opitz, President

(414) 284-5746

Louis G. Audette, Technical Consultant

5 Science Park

New Haven, CT 06511

Louis G. Audette

(203) 786-5104

Ayres Associates

2445 Darwin Road

Madison, WI 53704

Richard Otis, Vice President

(608) 249-0471

Ayres, Lewis, Norris and May, Inc.

2330 E. Stadium Blvd.

Ann Arbor, MI 48104

Abe A. Munfran

(313) $971-7800$

BCM Engineers

One Plymouth Meeting

Plymouth Meeting, PA 19462

Ashok Soni, P.E.

(215) $825-3800$

BEI Associates, Inc.

(Formerly Blount Engineers, Inc.)

601 West Fort Street

Detroit, MI 48226

Christopher P. Kittides, P.E.

(313) $963-2300$

Barrett Consulting Group

3000 Alpine Road

Menlo Park, CA 94025

Frank H. Barrett

(415) 854-7090

Barton \& Loguidice, P.C.

290 Elwood Davis Road

Liverpool, NY 13088

Paul F. Dudden, P.E.

(315) 457-5200 
Baymont Engineering Co. 14100 - 58th Street North

Rubin Icot Center

Clearwater, FL 34620-3796

Leo Flman, Vice President

(813) 539-1661

Beaumont Environmental, Inc.

P. O. Box 530

Wheatley Heights, NY 11798

Klaus S. Feindler, President

(516) 491-1565

Bechtel Civil, Inc.

Hydro and Community Facilities Diviion P.O. Box 3965

San Francisco, CA 94119

Emile H. Houle

(415) 768-5046

Bechtel Civil, Inc.

8618 Westwood Center Drive, Suite 300

Vienna, VA 22180

Andrew G. Magyar, Manager,

Business Development

(703) 761-7311

Benham Group, The

P. O. Box 20400

Oklahoma City, OK 73156

John F. Benham

(405) 478-5353

Benatac Associates

101 Eford Road

Camp Hill, PA 17011

Hendrik Johgsma

(717) 763-7391

Black and Veatch

1500 Meadow Lake Parkway

Kansas City, MO 64114

L. T. Schaper

(913) 339-3114
Blakely Buturla Consulting Engineers

621 South Fourth Avenue

Caldwell, ID 83605

Ronald M. Blakley

Frank J. Buturia

(208) 454-3033

Blank, Wesselink, Cook \& Associates, Inc. 2623 East Pershing Road

Decatur, IL 62526

William F. Blank

(217) 428-0973

Blaylock, Threet, Phillips \& Associates Incorporated

1501 Market Drive

Little Rock, AR 72211

Rawland Blaylock, Chairman of Board

(501) 244-3922

Booker \& Associates, Inc.

1139 Olive Street

St. Louis, MO 63101

J. E. Moulder

(314) 421-1476

Bovay Engineers, Inc.

1919 Smith Street

Houston, TX 77001

M. J. Stegner

(713) 651-9922

The Breisch Co., Inc.

16 South Main

Sand Springs, OK 74063

W. B. Breisch, President

(918) 245-9533

Briley, Wild \& Associates, Inc.

1042 U.S. 1, North

P. O. Box 607

Ormond Beach, FL 32074

Harry E. Wild, Jr., P.E.

(904) 672-5660 


\section{Brown and Caldwell}

P. O. Box 8045

Walnut Creek, CA 94596

Hilary M. Theisen, Vice President

(415) 937-9010

\section{Brown Engineering Company}

1051 Office Park Road

West Des Moines, IA 50265

Jay R. Read, P.E., President

John F. Kintz, P.E., Manager of

Field Services

(515) 225-6900

Brown Vence \& Associates

120 Montgomery St., Suite 680

San Francisco, CA 94014

Michael D. Brown, President

(415) 434-0900

Buchart-Horn, Inc.

55 South Richland Ave.

P. O. Box M-55

York, PA 17405

Raymond M. Best

(717) 843-5561

Bucher \& Willis Consulting Engineers, Planners \& Architects

609 West North Street

Salina, KS 67401

Stpehen L. Jennings

(913) 827-3603

\section{Burgess \& Nipple Limited}

5085 Reed Road

Columbus, $\mathrm{OH} 43220$

Mark Rowland

(614) 459-2050

H. H. Burkitt Project Management, Inc.

P. O. Box 8549

Portland, OR 97207

H. H. Burkitt, President

(503) 227-0336
Burns \& McDonnell Engineering Co.

P. O. Bo 419173

Kansas City, MO 64141-0173

Walter C. Womack

(816) $333-4375$

Burns and Roe Company

800 Kinderkamack Road

Oradell, NJ 07649

R. F. Sabia, Vice President, Engineering Services

(201) $265-2000$

Burns and Roe Industrial Services Corporation

700 Kinderkamack Road

Oradell, NJ 07649

R. F. Sabia, Vice President, Engineering Services

(201) $265-2000$

C. E. Kitson and Associates

22 Poplar Drive

Osterville, MA 02655

Charles E. Kitson, President

(508) 428-2886

CH2M Hill, Inc.

2300 N.W. Walnut Blvd.

P. O. Box 428

Corvalis, OR 97339

S. LaMont Matthews, Vice President, Industrial and Energy Systems

(503) $752-4271$

CI Resource Systems, Inc.

88 Broad Street

Boston, MA 02110

James L. Barker, Chairman

Joseph L. Boren, President

(617) 542-3070

Cal Recovery Systems, Inc.

160 Broadway, Suite 200

Richmond, CA 94804

George M. Savage

Luis F. Diaz

(415) 232-3066 
Campbell \& Associates, Inc.

701 East Fourth Street

Chattanooga, TN 37403

John F. Germ, President

(615) 267-9718

Camp Dreser \& McKee, Inc.

One Center Plaza

Boston, MA 02108

James T. O'Rourke,

Senior Vice President

Walter R. Niessen

(617) 742-5151

Carter and Burgess, Inc.

1100 Macon Street

P. O. Box 2973

Fort Worth, TX 76113

J. Steve O'Kelley, P.E.

(817) 335-2611

Cashin Associates, P.C.

255 Executive Drive

Plainvie, NY 11803

Alfred J. Angiola, P.E.

(516) $349-1010$

Century Engineering, Inc.

32 West Road

Towson, MD 21204

Richard O. Beall, Vice President

(301) 823-8070

Charles River Associates

John Hancock Tower

200 Clarendon St.

Boston, MA 02116

Mr. S. L. Blum, Sr.

(617) 266-0500

Charles R. Velzy Associates, Inc.

Subsidiary of Roy F. Weston, Inc.

355 Main Street

Armonk, NY 10504

Charles O. Velzy, P.E., President

(914) 273-9840
Charles W. Greengard Associates, Inc.

231 Old Half Day Road, Lincolnshire

P. O. Box 151

Prairie View, IL 60069

Don R. Fielding, P.E.

(312) 634-3883

Chas. T. Main, Inc.

Southeast Tower

Prudential Center

Boston, MA 02199

Sidney B. Barnes, Vice President

Power Division

(617) 262-3200

Chen and Associates, Inc.

96 South Zuni Street

Denver, CO 80223

Richard C. Hepworth

Dave Jubenville

(303) 744-7105

Clinton Bogert Associates:

2125 Center Avenue

Fort Lee, NJ 07024

Ivan L. Bogert, Managing Partner

(201) 944-1676

Co-La, Inc.

P. O. Box 4511

Florence, SC 29502

Gordon Langeland

(803) 669-0963

Compton Engineering

P. O. Box 686

Pascagoula, MS 39567

Lloyd Compton

(601) 762-3970

Consoer Townsend \& Associates, Inc.

Municipal and Environmental

Consulting Engineers

Three Illinois Center

303 East Wacker Drive, Suite 600

Chicago, IL 60601

Ray Heitner

(312) 938-0300 
Conversion Technology, Inc. 3300 Holcomb Bridge Rd.

Norcross, GA 30092

P. H. Haroz, President

(404) 263-6330

Daily \& Associates, Engineers, Inc. 816 Dennison Drive

Champaign, IL 61820

John P. Higgins

(217) $352-4169$

Dames \& Moore

7101 Wisconsin Ave.

Suite 700

Bethesda, MD 20814

M. David Maloney, Ph.D.,

Principal-in-Charge

(301) 652-2215

Demopulos and Ferguson, Inc.

330 Marshall St., Suite 700

Shreveport, LA 71101

Chris Demopulos

(318) 221-7117

Domingue, Szabo \& Associates, Inc.

117 Pinhook Road

Lafayette, LA 70505

Emergy Domingue, President

(318) 232-5182

Donald L. Hamlin, Consulting Engineers, Inc. P. O. Box 9

Essex Junction, VT 05452

Donald I. Hamlin

(802) 878-3956

Doucet \& Mainka, P.C.

2123 Compound Rd.

Peeskill, NY 12566

Christian Mainka, P.E.

(914) 736-0300

Dubois \& King, Inc.

Box 339

Randolph, VT 05060

William H. Baumann, Jr, P.E.,

President

(802) 728-3376
Dunbar Biotechnical Engineers

1286 West Lane Avenue

Columbus, OH 43221

Robert A. Dunbar, P.E.

(614) 486-0206

Dyer \& Moody, Inc.

P. O. Box 700

Baker, LA 70714

Lamon L. Moody, Jr. P.E.

(504) 775-4800

EA-Mueller, Inc.

1401 South Edgewood Street

Baltimore, MD 21227

Joseph A. Mulloney, Jr.

(301) 656-4500

E. C. Jordan Co.

P. O. Box 7050

Portland, ME 04112

Stanley E. Walker,

Vice President

(207) 775-5401

Earth Resources Technology Services

c/o Computer Showcase

Tower Plaza Mall

3885 E. Thomas Rd.

Phoenix, AZ 85018

Quentin J. Adams, President

(602) 267-9363

Ebasco Services, Inc.

Two World Trade Center, 93rd Fl.

New York, NY 10048

Harvey Sands, Marketing

Director

(212) $839-1110$

Ellerbe Becket

One Appletree Square

Bloomington, MN 55420

Doug Maust, P.E.,

Vice President

(612) 853-2347 
Emcon Associates

1921 Ringwood Avenue

San Jose, CA 95131

John Pacey

(408) 275-1444

Energy Research and Design Assoc.

410 South Cache

Box 3177

Jackson, WY 83001

Jim Kleyman

(307) 733-8018

Entranco Engineers

5808 Lake Washington Blvd., NE

Suite 200

Kirkland, WA 98033

Jim Doesburg

(206) 827-1300

Environmental Elements Corp.

Waste Disposal Systems Group

P. O. Box 1318

3700 Koppers Street

Baltimore, MD 21203

Mark J. Girovich, Manager of

Engineering, Waste Disposal

(301) 368-6737

Eseor, Ine.

540 Frontage Rd., Sestech Corp.

Mr. Eric Zimmerman

(312) $501-2190$

Estech Corp.

1907 American Drive

Neenah, WI 54956

Wayne P. Sorenson

(414) 725-6555

Flood Engineers - Architects - Planners; Frne.

6501 Arlington Expressway

P. (O. Box 8869

Jacksønville, FL 32211

John H. Flood, Jr., President

(904) 724-3990
Foth \& Van Dyke, Inc.

2737 South Ridge Road

P. O. Box 19012

Green Bay, WI 54307-9012

Craig L. Berndt, P.E.,

Manager, Environmental

Process Engineering

(414) 497-2500

Four Nines, Inc.

P. O. Box 701

Conshohocken, PA 19428

Yen-Hsiung Kiang, Ph.D., P.E.

(215) 834-0490

Franklin Associates, Ltd. 4121 W. 83rd St., Suite 108

Prairie Village, KS 66208

Marjorie A. Franklin

(9.13) 649-22225

Fred C. Hart Associates, Inc.

530 Fifth Ave.

New York, NY 10036

Fred: C. Hart, President

(212) 840-3990

Freese \& Nichole, Inc.

811 LaMar Street

Fort Worth, TX 76102

Robent [.. Nichols, P.E.,

President

(817) 336-7161

Fromherz Engineers, Inc.

4747 Earhart Blvd.

P. O. Box 13784

New Orleans, LA 70185

Frank C. Fromherz II, P.E.,

Vice President

(504) 488-7711

Fuehrer Associates

345 West Main Street

Ephrata, PA 17522

John G. Fuehrer II, P.E.

(717) 733-9658 
GEI Consultants, Inc.

1021 Main Street

Winchester, MA 01890

Steve J: Poulos, President

(617) 721-4000

Gannet Fleming

P. O. Box 1963

Harrisburg, PA 17105

Richard N. Koch, AICP

(717) 763-7211

Geotechnical Consultants, Inc. 1023 East Thompson Blvd.

Ventura, CA 93001

Joe Gonzalez

(805) 643-2203

Geotechnical Engineers, Inc.

1017 Main Street

Winchester, MA 01890

Ronald C. Hirshfeld, President

(617) 729-1625

Geo-Technical Services, Incorporated 851 South 19th Street

Harrisburg, PA 17104

Gideon Yachin, P.E., Vice President

(717) 236-3006

Geotechnics, Inc.

912 Bryden Rd.

Columbus, $\mathrm{OH} 43205$

Dr. Charles Moore

(614) 253-0198

Gershman, Brickner \& Bratton, Inc.

2735 Hartland Road

Falls Church, VA 22043

Harvey W. Gershman, President

(703) $573-5800$

Gibbs \& Hill, Inc.

11 Penn Plaza

New York, NY 10001

Murray Skopinsky

(212) 216-6066
Gilbert/Commonwealth

P. O. Box 1498

Reading, PA 19603

G. J. Davidson

(215) 775-2600

Gira S.A.

1239 Collex/Geneva

Geneva, Switzerland

Dr. Ian R. Gordon, Director

(22) 741010

Gove Associates, Inc.

1601 Portage Street

Kalamazoo, MI 49001

D. Romes, P.E.

(616) 385-0011

Graef, Anhalt, Schloemer \& Associates, Inc. 345 N. 9th Street

Milwaukee, WI 53226

Luther W. Graef

(414) $259-1500$

Graham \& Associates, Professional

Consulting Engineers, Inc.

2000 Classen Center, Suite 110 South

Oklahoma City, OK 73106

Jack H. Graham

(405) 528-5611

Greeley and Hansen

222 South Riverside Plaza

Chicago, IL 60606

E. F. Ballotti, P.E.

(312) 648-1155

Greenbaum Associates

994 Longfield Ave.

Louisville, KY 40215

Milton M. Greenbaum, P.E.

(502) $361-8447$

Greiner Engineering, Inc.

300 East Carpenter Freeway, Suite 1210

Irving, TX 75062

F. T. Callahan, P.E.

(214) 258-6208 
H2M Group

575 Broad Hollow Rd.

Melville, NY 11747

Robert G. Holzmacher, President

(516) 756-8000

\section{HDR Engineering}

2415 Campus Drive, \#201

Irvine, CA 92715

Frederick C. Rice

(714) 476-0336

H. F. Lenz Company

1735 Lyter Drive

Johnstown, PA 15905

Charles J. Neuhoff, P.E., President

(814) 255-5821

H. G. E. Incorporated Engineers and Planners 19 Northwest Fifth Avenue

Portland, OR 97209

Roy H. Erichsen, P.E., President

(503) 222-1687

H. R. Kornblum, P. E.

11 East 32nd Street

New York, NY 10016

H. R. Kornblum

(212) 683-0422

HTB, Incorporated

1411 Classen Boulevard

Oklahoma City, OK 73106

P. G. Wilson, Jr.

(405) 525-7451

Hankins \& Anderson, Inc.

1604 Santa Rosa Road

Richmond, VA 23288

Creed T. Elliotte

(804) 285-4171

Harding Lawson Associates

7655 Redwood Boulevard

P. O. Box 578

Novato, CA 94948

Victor R. Johnson, Jr.

(415) 892-0821
Harland Bartholomew \& Associates

300 Hunter Avenue

St. Louis, MO 63124

Robert B. Bax

(314) 726-1300

Harza Engineering Company

150 South Wacker Drive

Chicago, IL 60606

Eric Yould

(312) $855-7000$

Havens and Emerson, Inc.

700 Bond Court Building

1300 E. Ninth Street

Cleveland, $\mathrm{OH} 44114$

Gary M. Siegel

(216) 621-2407

Hawk Engineering, P.C.

P. O. Box 427

Binghamton, NY 13902

Kenneth C. Hawk, Jr., P.E.

(607) 648-4168

Hayden-Wegman, Inc.

2200 Century Parkway, Suite 280

Atlanta, GA 30345

Henry Hornsby, Executive

Vice President

(404) $325-5400$

Hayes, Seay, Mattern and Mattern, Inc.

1315 Franklin Road, SW

P. O. Box 13446

Roanoke, VA 24034

H. Boyd Dickenson

(703) 343-6971

Hazen and Sawyer, P.C.

730 Broadway

New York, NY 10003

C. Richard Walter

(212) 777-8400 
Henningson, Durham and Richardson

8404 Indian Hills Drive

Omaha, NE 68114

Frank A. Borchardt, P.E., Vice President

(402) 399-1000

Hensley-Schmidt, Inc.

120 Interstate North Pkwy., Suite 450

Atlanta, GA 30339

Joe A. Hastey

(404) 952-8861

Hercules, Inc.

P. O. Box 210

Rocket Center, WV 26726

Joe DeGiovanni

(304) 726-5454

Howard E. Hesketh, P.E.

RR 4, Box 176

Carbondale, Il 62901

Howard E. Hesketh, Ph.D

(618) 536-2396

Hollander \& Associates

1605 Sherwood Road

Wyomissing, PA 19610

Herbert I. Hollander, P.E., Dipl.

(215) 678-9756

Horner \& Shifrin, Inc.

5200 Oakland Ave.

St. Louis, MO 63110

Tom Thompson

(314) 531-4321

Howard K. Bell, Consulting Engineers, Inc. 354 Walter Avenue

P.O. Box 546

Lexington, KY 40585

J. David Hitehouse

(606) 278-5412

Howard Needles Tammen \& Bergendoff 225 N. New Jersey St.

Indianapolis, IN 46204-2135

Stephen G. Goddard

(317) 686-4682
Howard R. Green Company

4250 Glass Road, NE

P. O. Box 9009

Cedar Rapids, IA 52409

E. V. Yoerger

(319) 395-7805

Huth Engineers, Inc. 1650 Manheim Pike

P. O. Box 3012

Lancaster, PA 17604

Russell N. MacNair

(717) 569-7021

I. C. Thomasson Assoc., Inc. 2120 Eighth Avenue, South

Nashville, TN 37204

Dr. Carroll Chambliss, P.E., Vice President, Solid Waste Resource Recovery

(615) 383-6821

Inberg-Miller Engineers

124 East Main Street

Riverton, WY 82501

Howard M. Johnson, President

(307) 856-8136

Intergy

Ricwil Piping Systems

10100 Brecksville Road

Breckville, OH 44141

Keith Kleve

(216) $526-1600$

J. H. Kleinfelder \& Associates

1901 Olympic Boulevard, Suite 300

Walnut Creek, CA 94596

J. H. Kleinfelder, President

(415) 938-5610

James M. Montgomery, Consulting Engineers, Inc.

250 North Madison Avenue

Pasadena, CA 91101

J. Patrick McKee

R. Rhodes Trussell

(818) 796-9141 
John Carollo Engineers

450 North Wiget Lane

Walnut Creek, CA 94598

H. Harvey Hunt

(415) 932-1710

John G. Reutter Associates

800 Hudson Square, Suite 300

Camden, NJ 08101

John G. Reutter, President

(609) 541-7700

John S. MacNeill, Jr., P.C.

74 North West Street

P. O. Box 320

Homer, NY 13077

John S. MacNeill, Jr., P.E.-L.S., President

(607) $749-2644$

KSA, Inc.

P. O. Box 1552

911 N.W. Loop 281

Longview, TX 75606

K. W. Kindle

(214) 297-7700

KZF, Inc.

655 Eden Park Drive, Suite 750

Cincinnati, OH 45202

George J. Kral, Chairman of the Board

(513) 621-6211

Kadrmas, Lee and Jackson, P.C. East Hwy. 10

P. O. Box 290

Dickinson, ND 58601

Gene Jackson

(701) 227-1284

Kaiser Engineers, Inc.

1800 Harrison Street

P. O. Bo 23210

Oakland, CA 4623-2321

Dr. B. S. Ausmus, Manager, Environmental Control and Remediation

(415) 268-6246
Keck \& Wood, Inc.

3722 Pleasantdale Road

Atlanta, GA 30340

Charles C. Corbin, Jr.

(404) 939-1334

Kennedy/Jenks/Chilton

3585 Maple Street, Suite 226

Ventura, CA 93003

Lynn Takaichi

(805) 658-0607

\section{Keyes Associates}

321 South Main Street

Providence, RI 02903

Walter I. Keyes

(401) 861-2900

Kidde Consultants, Inc. 1020 Cromwell Bridge Road

Towson, MD 21204

Thomas M. Simpson

(301) 321-5572/5500

Killam Associates, Consulting Engineers

27 Bleeker Street

Millburn, NJ 07041

Eugene J. Destefano, Executive

Vice President

(201) 379-3400

Kindle, Stone \& Associates, Inc.

P. O. Box 1552

911 N.W. Loop 281

Longview, TX 75606

K. W. Kindle

(214) 297-7700

Konheim \& Ketcham, Inc.

175 Pacific Street

Brooklyn, NY 11201

Carolyn S. Konheim

(718) 330-0550

Konski Engineers, P.C.

Old Engine House No. 2

722 North Salina Street

Syracuse, NY 13208

James L. Konski, P.E.

(315) 471-2101 
Kuepper Associates

15 Stelton Road

Piscataway, NJ 08855-0036

Harry S. Allen, P.E.

(201) 752-5600

\section{Laberge Engineering \& Consulting Group} Ltd.

4 Computer Drive

Albany, NY 12205

Ronald H. Laberge, P.E.

(518) $458-7113$

Larsen

700 West Metro Park

Rochester, NY 14623

(716) 272-7310

Law Environmental, Inc.

Executive Square

5510 Gray Street, Suite 118

Tampa, FL 33609

C. R. Lemos, P.G.

(813) 877-9182

Lizardos Engineering Associates, P.C. 1125 Willis Avenue

Albertson, NY 11507

George J. Lizardos, P.E.

(516) 484-1020

Lockman \& Associates

249 East Pomona Boulevard

Monterey Park, CA 91754

W. J. Lockman

Ronald J. Lofy

(213) 724-0250/727-7971

Lockwood, Andrews \& Newman, Inc. 1500 City West Boulevard

Houston, TX 77042

James K Wilheim, President

(713) $266-6900$

Louis Berger International, Inc.

100 Halsted Street

East Orange, NJ 07019

Andrew Bielloch

(201) 678-1960
Luis Lemus Consulting Engineers, Inc.

5757 Wood Way, \#220

Houston, TX 77057

Luis Lemus, Jr.

(713) $526-2263$

Lutz, Daily and Brain

6400 Glenwood

Overland Park, KS 66202

Jack F. Daily, P.E.

Fred J. Lutz, P.E.

(913) 831-0833

MHM Associates, Inc. 1920 Ridgedale Road

South Bend, IN 46614

M. H. Mohajeri, P.E.

(219) 291-4793

MK-Ferguson Company

A Morrison Knudsen Company

One Erieview Plaza

Cleveland, $\mathrm{OH} 44114$

William G. Rueb

(216) 523-5911

McDonough Associates, Inc.

224 South Michigan Avenue

Chicago, IL 60604

James J. McDonough, President

(312) 922-2100

McFarland-Johnson Engineers, Inc.

P. O. Box 1980

Binghamton, NY 13902

Thomas Coughlin, P.E., President

(607) 723-9421

McMahon Associates, Inc.

1377 Midway Road

Menasha, WI 54952

Thomas Vik, P:E.

(414) 739-0351

McNamee, Porter and Seeley

3131 South State Street

Ann Arbor, MI 48108

Raymond J. Smit, Partner

(313) 665-6000 
Macomber Associates, Inc.

704 Lisburn Road

P. O. Box 78

Camp Hill, PA 17011-0078

Victor D. Macomber

(717) 761-6660

Malcolm Pirnie, Inc.

301 Hiden Blvd.

Newport News, VA 23606

R. F. Bonner, Jr.

(804) 599-5511

Mandeville \& Associates

526 Hofgaarden St.

City of Industry, CA 91744

Richard Mandeville, Senior Professional

(818) 369-2224

Mansur-Daubert-Strella, Inc.

1648 South Boston Avenue

Tulsa, OK 74119

George G. Strella, P.E.

(918) 584-0347

Mesch Engineering, P.C.

285 Market Street

P. O. Box 451

Lockport, NY 14094

Andrew W. Lindsay, Jr., P.E.

(716) 434-6276

Metcalf \& Eddy, Inc.

P. O. Box 4043

Woburn, MA 01888-4043

James Osborn

(617) 246-5200

Michael Baker, Jr., Inc.

Box 280

Beaver, PA 15009

Richard L. Shaw

(412) 495-7711

Midwesco Energy Systems

7720 Lehigh Avenue

Niles, IL 60648

Ralph Berman

(312) 966-2150
Thomas R. Miles

Consulting Design Engineers

5475 Southwest Arrow Wood Lane

Portland, OR 97225-1323

Thomas R. Miles, P.E.

(503) 292-0107

Mitre Corporation

Department of Energy, Resources and Environmental Systems

7525 Colshire Drive

McLean, VA 22102

Abu Talib

(703) 883-6901

Morrison Geotechnical Engineering

P. O. Box 399

Waterville, ME 04901-0399

Edward B. Morrison

(207) 873-4283

Morrison-Maierle, Inc.

910 Helena Avenue

P. O. Box 6147

Helena, MT 59604

Rodger Foster

(406) 442-3050

Mueser Rutledge Consulting Engineers

708 Third Avenue

New York, NY 10017

George J. Tamaro, Partner

(212) 490-7110

Municipal Recycling Associates, Inc.

Tarry Elm Business Center

3 West Main Street

Elmsford, NY 10523

Dr. Allen Hershkowitz

(914) 345-5820

NBS/Lowry, Inc.

10920 Via Frontera

P. O. Box 28100

San Diego, CA 92128

D. S. Martinson 
Nebraska Testing Laboratories, Inc. 4453 South 67th Street

Omaha, NE 68117

Dan E. McCarthy

(402) $331-4453$

Neyer, Tiseo, \& Hindo, Ltd.

38955 Hills Tech Dr.

Farmington Hills, MI 48331-3432

Jerome C. Neyer, President

(313) 553-6300

O'Brien \& Gere Engineers, Inc.

1304 Buckley Road

P. O. Box 4873

Syracuse, NY 13221

Joanne B. Stobnicke

(315) 451-4700

Omega Conversion, Inc.

11.37 N. Woodbine Ave.

Narberth, PA 19072

Kenneth H. Hladum

(215) 664-6555

One America, Inc.

1523 L Street, NW, Seventh Floor Washington, DC 20005

Avi Bender, Project Manager

(202) 628-2216

PMA, Inc.

Air Pollution Control Technology

P. O. Box 360626

Birmingham, AL 35236-0626

John E. Paul, President

(205) 988-8192

PSG Corrosion Engineering, Inc.

Corrosion Engineers

1650 Mutual Building

28 West Adams

Detroit, MI 48226

John H. Fitzgerald, III, P.E.

Mary A. Gruchala

(313) 962-5272
Parrott, Ely \& Hurt, Consulting Engineers

620 Euclid Avenue

Lexington, KY 40502

George D. Parrott

(606) 266-2144

Paul N. Fontenot, Inc.

P. O. Box 499

South Chataignier Road

Ville Platte, LA 70586

Paul N. Fontenot

(318) 363-4751

Peat, Marwick, Main \& Co.

Management/Financial Consulting

2001 M Street, NW

Washington, DC 20036

Melvin P. Paret, Manager

(202) 467-3000

Pennoni Associates, Inc.

1911 Arch Street

Philadelphia, PA 19103

C. R. Pennoni, President

(215) 561-0460

Perkins and Associate, Inc.

P. O. Box 219

Russellville, AR 72801

Richard Perkins, President

(501) 968-1885

Pickard and Anderson

69 South Street

Auburn, NY 13021

William C. Anderson, P.E., Managing Partner

(315) 253-4433

Piedmont Group, The

P. O. Box 1717

Greenville, SC 29602

John Bayette, P.E., President

(803) 242-1717 
Planning Associates

369 Cerro

Encinitas, CA 92024

John L. Deuble, Jr., Principal

(619) 436-3559

Polyengineering

2480 Government Boulevard

Mobile, AL 36606

Arnold E. Parsons, P.E., President

Joseph V. Dust, P.E., Ph.D.

(205) 476-1446

Pope Engineers

One Penn Plaza

New York, NY 10119

John E. Mesko, P.E.

(212) 456-5500

Pope-Reid Associates, Inc.

245 East Sixth Street, Suite 813

St. Paul, MN 55101

Robert J. Reid, P.E. President

(612) $227-6500$

Post, Buckley, Schuh \& Jernigan, Inc.

800 North Magnolia Ave., Suite 600

Orlando, FL 32803

David E. Deans, P.E.

(305) 423-7275

\section{R. A. Wright Engineering}

Women's Business Enterprise (WBE)

1340 Southwest Bertha Boulevard

Portland, OR 97219

Kathleen Thomas, P.E., President

(503) 246-4293

RCG/Hagler, Bailly, Inc.

370 L'Enfant Promenade, SW, Suite 700

Washington, DC 20024-2518

Jean-Louis Poirier,

Senior Vice President

(202) $488-1500$

RGA Engineering Corp.

877 S. Alvernon Way

Tucson, AZ 85711

Rod J. Gomez, P.E., CEO

(602) 881-4309
RMT, Inc.

Great Lakes Office

P. O. Box 447

Grand Ledge, MI 48837

Robert E. Zayko

(517) 627-4040

R. M. Towill Corp. 420 Waiakamilo Road, Suite 411

Honolulu, HI 96817

William E. Spencer, Jr.

(808) 842-1133

R. Stuart Royer \& Associates

8227 Hermitage Rd.

Richmond, VA 23228

T. F. Turner, Jr.

(804) 264-3915

R. W. Beck and Associates

Solid Waste Resource Recovery

Department

1125 17th Street, Suite 1900

Denver, CO 80202

E. Larry Beaumont

(303) 295-6900

Ralph Stone \& Company, Inc.

10954 Santa Monica Blvd.

Los Angeles, CA 90025

Richard Kahle, P.E.

(213) 478-1501

Raphael Katzen Associates Intenational, Inc. 7162 Reading Road, Suite 1200

Cincinnati, OH 45237

Raphael Katzen

(513) 351-7500

Recon Systems, Inc.

Route 202 North

P. O. Box 460

Three Bridges, NJ 08887

Richard F. Toro,

Executive Vice President

(201) 782-5900 
Resource Conservation Consultants

1206 N.W. 21

Portland, OR 97209

Jerry Powell

(503) 227-1319

Resource Consultants, Inc.

7121 Cross Roads Boulevard

P. O. Box 1848

Brentwood, TN 37024-1848

James C. North, President

(615) 373-5040

Resource Technology Corp.

P. O. Box 237

Cupertino, CA 95015-0237

Ronald D. Kinsey, President

(408) 996-8611

Reynolds, Smith and Hills

Architects-Engineers-Planners

6737 Southpoint Drive South

Jacksonville, FL 32216

J. B. Miller, Jr., Senior Vice President -

Power

(904) $739-2000$

Rhutasel \& Assoc., Inc.

\#1 Sunset Drive

P. O. Box D

Freeburg, IL 62243

Larry J. Rhutasel, P.E.

(618) 539-3178

Richard A. Alaimo, Associates

200 High Street

Mt. Holly, NJ 08060

Richard A. Alaimo

(609) 267-8310

Rigo \& Rigo Associates, Inc.

Building 3, Suite 211

Berea Commons

Berea, OH 11017

H. Gregor Rigo, President

(216) 243-5544
Rist-Frost, Associates, P.C.

21 Bay Street

Glens Falls, NY 12801

Fil Fina, Jr.

(518) 793-4141

Robert and Company

96 Poplar Street, NW

Atlanta, GA 30303

L. W. Robert IV

(404) $577-4000$

Robert E. Hamilton, Consulting

Engineers, P.C.

1013 Dawes Avenue

Joliet, IL 60435

Robert E. Hamilton

(815) 722-3444

Robson \& Woese Inc.

5895 Enterprise Pkwy.

P. O. Box 0606

E. Syracuse, NY 13057-0606

Thomas A. Doganieri, Vice President

(315) 445-2650

\section{Roger, Golden and Halpern}

1216 Arch Street

Philadelphia, PA 19107

John Rogers, President

(215) 563-4220

Ross Hofmann Associates, Inc.

2903 Salzedo Avenue

Coral Gables, FL 33134

Ross E. Hofmann, President

(305) 445-5376

Rowe Engineering, Inc. 1449 East Pierson Road

Flushing, MI 48433.

David T. Rowe

William J. Winiarski

(313) 659-3103

Roy F. Weston, Inc.

Weston Way

West Chester, PA 19380

A. William Hogeland, P.E., Vice President

(215) 692-3030 
Rycon, Inc.

P. O. Box 17129

Cincinnati, OH 45217

Dr. Boyd T. Riley

(513) 861-2655

SCS Engineers

3711 Long Beach Boulevard

Long Beach, CA 90807

David E. Ross

(213) 426-9544

Sea Consultants

485 Mass. Ave.

Cambridge, MA 02139

Arnold B. Goldstein

(617) 497-7800

SPM Group, Inc.

1019 E. Easterly Way

Littleton, CO 80122

Konrad Rucktuhl, President

(303) 798-5949

\section{STS Consultants}

111 Pfingsten Road

Northbrook, IL 60062

John Gnaedinger, P.E.

(312) 272-6520

STV Engineers

11 Robinson Street

Pottstown, PA 19464

E. E. Gilvey, P.E.,

Executive Vice President

William P. May, P.E.,

Vice President

(215) 326-4600

STV/Sanders and Thomas, Inc.

11 Robinson Street

Pottstown, PA 19464

F. R. Carpentier, P.E., Vice President

William P. May, P.E., Vice President (215) 326-4600
Schneider Engineers

98 Vanadium Road

Bridgeville, PA 15017

Dr. Joseph Duckett

(412) 221-1100

Science Applications International Corporation

4300 King Street, Suite 310

Alexandria, VA 22302

Dick Richards

(703) 998-0931

Scott Civil Engineering Co.

1201 McKay Tower

Grand Rapids, MI 49503

Robert H. Scott, P.E.

(616) 458-8792

Scott Engineering Company

1904 Ninth Avenue, SE

Watertown, SD 57201

John Scott

(605) 886-5725

Sear-Brown Group

30 Court Street

Canton, NY 13617

David W. Magurk, Associate

(315) 386-4527

Seifert \& Associates

1204 E. Dorothy Lane

Dayton, OH 45419

Ted Green

(513) 299-3516

Shaffer, Krimmel, Silver and Associates, Inc. 2900 N. Martin Luther King Jr. Drive

P. O. Box 2233

Decatur, IL 62526

Robert Krimmel

(217) $877-2100$

Shannon \& Wilson, Inc.

11500 Olive Boulevard, Suite 276

St. Louis, MO 63141

J. Ronald Salley

(314) 872-8170 
Shaw, Weiss \& DeNaples, P.C.

14 West First Street

Dayton, OH 45402

George B. Shaw, P.E. P.S,

President

Sheladia Associates, Inc.

15825 Shady Grove Road

Rockville, MD 20850

Asok K Motayed, P.E.

(301) 258-7474

Shive-Hattery Engineers and Architects, Inc.

Highway 1 \& Interstate 80

P. O. Box 1050

Iowa City, IA 52244

William B. Cook, P.E., Environmental

Department Manager

(319) 354-3040

Smith \& Mahoney, P.C.

79 North Pearl Street

Albany, NY 12207

Michael W. McNerney

(518) 463-4107

Smith Seckman Reid, Inc.

3319 West End Ave., Suite 700

Nashville, TN 37203

Stephen C. Lane, Vice President

(615) 383-1113

\section{Speitel Associates}

302 Evesham Commons

Route 73 and Evesham Road

Marlton, NJ 08053

Gerald E. Speitel

(609) 596-6600

Staal, Gardner \& Dunne, Inc. 121 North Fir Street, Suite F

Ventura, CA 93001

Ivar Staal, President

(805) 653-5556
Staunton/Chow Engineers, P.C.

14 East 33rd St.

New York, NY 10016

Kin Chow, P.E.

Jose R. Cardenas, P.E.

(212) 683-8865

Stearns Roger Division

United Eng. \& Const., Inc.

700 Ash Street

P. O. Box 5888

Denver, CO 80217

Edward W. Stenby

(303) 692-2252

Stone \& Webster Engineering Corp.

250 W. 34th Street

New York, NY 10116

Jeffrey M. Levy

(212) 290-6103

Storch Engineers

220 Ridgedale Avenue

Florham Park, NJ 07932

William L. Deane

(201) $822-2600$

Sverdrup Corporation

801 North Eleventh

St. Louis, MO 63101

H. Gerard Schwartz, Jr.

(314) 436-7600

Syska \& Hennessy, Inc.

11 West 42nd Street

New York, NY 10036

John F. Hennessy, Chairman and

Chief Executive Officer

(212) $921-2300$

Systech Corporation

245 North Valley Road

Xenia, OH 45385

Arthur J. Helmstetter, P.E.

(513) 372-8077 
T \& M Associates

1060 Highway 35

P. O. Box 828

Red Bank, NJ 07701

Kevin Toolan

(201) 671-6700

Tenech Engineering, Inc.

515 Park Avenue

Louisville, KY 40208

Joseph L. Pavoni

(502) 636-3565

Terre-Aqua Resource Engineering

1401 West Avenue North

P. O. Box 846

Crossville, TN 38557

T. C. Miller

(615) 484-7543

Thomas, Dean, \& Hoskins, Inc.

1200 25th Street, South

Great Falls, MT 59405

T. H. Thomas

(406) 761-3010

Toltz, King, Duvall, Anderson and Associates, Inc.

2500 American National Bank Building

St. Paul, MN 55101

DuWayne Kasma

(612) 292-4400

Total Energy and Materials Recovery

Company Inc.

Box 177, Star Rt.

Glens Falls, NY 12801

Robert L. Chulz, President

(518) 462-3438

Trans Environmental Engineers, Inc.

4043 Howe Road

Grand Blanc, MI 48439

Hanuman Marur, P.E.

(313) 743-2741
Transflux International, Inc.

One Marine Plaza

No. Bergen, NJ 07047

Miklos G. Kurz, P.E., President

(201) 861-2880

Triple Point Engineering

5439 Long Court

Appleton, WI 54915

Paul M. Kronberg, Owner

(414) 734-7775

URS Company

8700 Stemmons Freeway, \#201

Dallas, TX 75247

W. Clay Roming, P.E., President

(214) 630-3500

United Engineers \& Constructors, Inc.

30 South 17th Street

Philadelphia, PA 19101

Albert E. Rosica, Business Development

Representative

(215) $422-4796$

Vaughn \& Melton Engineers - Architects 219 West Depot Street

Greenville, TN 37743

M. W. Robertson

(615) 639-0271

W. A. Hirai and Associates

109 Holomua Street

P. O. Box 485

Hilo, HI 96720

Wallace A. Hiriai

(808) 935-1102

W. R. Clements, Inc.

P. O. Box 836

St. Marys, GA 31558

W. R. Clements, President

(912) 882-3570

Wade-Trim/Associates

25185 Goddard Road

Taylor, MI 48180

Doug Dail, P.E.

(313) 291-5400 
Wahler Associates

1023 Corporation Way

P. O. Box 10023

Palo Alto, CA 94303

Jack G. Wulff, President

(415) 968-6250

\section{Warzyn Engineering, Inc.}

One Science Court

Madison, WI 53705

Kenneth A. Nickels, P.E., S.E.,

Chief Design Engineer

Waste Energy Recovery Systems, Inc.

1000 John R. Road

Troy, MI 48083

Arthur Nicoll, President

(313) 589-3710

Watwood \& Heavener, Inc.

Highway 161 East

P. O. Drawer W

Centralia, Il 62801

Pete Baldwin

(618) 532-1971

Wehran Engineering

666 East Main Street

P. O. Box 2006

Middletown, NY 10940

Fred L. Wehran, Jr.

(914) 343-0660

Wendel Engineers, P.C.

11 Pinchot Ct.

Buffalo, NY 14228

Michael B. Turri, P.E.

(716) 625-6867

Western Michigan Environmental Services,

Inc.

245 East Lakewood Boulevard

Holland, MI 49424

Robert W. Hamm, Laboratory Director

(616) 396-1209
Whitman, Requardt and Associates

2315 St. Paul Street

Baltimore, MD 21218

J. Donald Paulus, Partner

(301) 235-3450

William Harrington \& Associates, Inc. 7310 Ritchie Highway, suite 818

Glen Burnie, MD 21061

William M. Harrington, Jr.

(301) 768-5400

Woodward-Clyde Consultants

1300 Piccard Drive

Rockville, MD 20850

Dr. Ronald E. Smith, Vice President

(301) 258-9780

Wright-Pierce

99 Main Street

Topsham, ME 04086

David R. Fuller

(207) 725-8721

YWC, Inc.

200 Monroe Turnpike

Monroe, CT 06468

Robert Q. Bradley, Vice President

(203) 261-4458

Zurheide-Herrmann, Inc.

4333 W. Clayton Avenue

St. Louis, MO 63110

Thomas A. Herrmann, Vice President

(314) 652-6805 
Appendix E

U.S. Regulatory, Research, and Legislative Activities Related to MWC Facilities 
1). S. REGULATURY, RESEARCH, AND LEgisLative

ACTIVITIES RELATED TO MWC FACILITIES

by

\author{
James D. Kilgroe \\ U. S. Environmental Protection Agency \\ Air and Energy Engineering Research Laboratory \\ Research Trangle Park, INC 27711
}

\title{
ABSTRACT
}

The U.S. Environmental Protection Agency (EPA) is currently developing air pollution emission rules for new and existing municipal waste combustion (MWC) facilities pursuant to Section 111 of the Clean Air Act (CAA). These rules are planned for proposal in November 1989 and promulgation in December 1990. This paper provides information on EPA's technical activities related to this regulatory effort. These activities include assessments of combustion and flue gas cleaning technologies employed at MWC facilities; the collection and evaluation of MWC air pollution emission test data; the development of technical recommendations for good combustion practices at MWC facilities; the development of model plants representative of existing and projected MWC facilities; and an evaluation of the performance of employing alternative combustion and flue gas cleaning strategies for controlling air emissions at these model MWC facilitios.

Proposed legislation is before the 101st Congress (S. 196) to control air pollutant emissions from municipal waste incineration and provide for safe disposal of ash. Key provisions of this proposed legislation are summarized.

This paper has been reviewed in accordance with the U. S. Environmental Protection Agency peer and administrative review policies and approved for presentation and publication. 


\section{INTRODUCTION}

In 1960, the U.S. generated waste at a rate of 2.65 pounds* per person per day; by. 1986, that figure had jumped to 3.58 pounds, and the rising trend is projected to continue into the Year 2000l. The generation of most types of municipal solid waste (MSW), including paper, plastics, glass, and metals, has increased (see Figure 1). A U.S. citizen generates approximately 1 pound per day more waste than his or her counterpart in West Germany, an equally industrialized nation.?

It is estimated that 80 percent of the nation's MSW is landfilled; only 10 percent is recycled, and 10 percent is incinerated or otherwise burned. At the same time that more wastes are being generated, the capacities for processing and disposal are diminishing. Since one-third of the nation's landfills will be full by 1991, the waste now disposed of in these facilities will have to be disposed of elsewhere. 3 Many existing facilities are closing either because they are filled or because they are not designed and operated in a manner which meets Federal or state standards for protection of human health and the environment.

Efforts to site new landfills, combustors, and recycling centers, however, are met with mounting public opposition. This opposition may stem from concerns about environmental or health risks from contaminated ground and surface waters and soil, from air pollution emissions from MWC, or from toxic residues produced by MWC facilities; from resistance to such nuisance factors as noise, odors, and truck traffic; or from anxiety over property values. Whatever the reasons, this opposition often results in the denial of requests to construct urgently needed new waste management facilities, especially MWC facilities.

There are two major public concerns in the U.S. related to pollution from MWC facilities. The first is the concern over air pollutant emissions, primarily dioxins and trace metals. The second is the concern over the leachability and toxicity of trace elements in MWC residues. EPA is currently developing new rules governing control of air pollution emission regulations from MWC facilities. The major part of this paper deals with the results of EPA activities in developing the air pollution emission control rules that are to be proposed later this year.

EPA is also developing a plan for the collection of information needed to promulgate guidelines for the management of MWC ash in, an environmentally sound manner. The development of ash management standards will be contingent on new environmental laws the lolst Congress is expected to pass in the near future. A brief summary of S.196, a Senate bill dealing with the control of air pollution emissions and the disposal of residues from MWC facilities, is the second topic of this paper.

*English Engineering Units rather than metric units are used here because of their customary use in the U.S. See Appendix for unit conversions. 
The paper also presents a brief summary of EPA organizations that are currently involved in the development of MWC regulations or that are engaged in research, development, or demonstration activities related to MWC

This paper presents the status of on-going work at EPA. In some cases draft reports or memoranda, which were distributed outside of the Agency for public comment, are provided for references. In some instances data in this paper represent up-dated versions of data from the draft references. The methodologies and data in the draft references are generally correct, but new information has resulted in the revision of the numerical results of studies.

\section{BACKGROUND}

The U.S. Environmental Protection Agency (EPA) regulates pollution from MWC facilities under authority of two major environmental laws: the Clean Air Act (CAA) and the Resource, Conservation, and Recovery Act (RCRA), an amendment of the Solid Waste Act (SWA). These Acts also authorize EPA to conduct research needed to ident ify environmental problems, and develop and demonstrate technology for pollution control.

\section{CLEAN AIR ACT}

The CAA and its amendments authorize EPA to carry out a national program of research, regulatory, and enforcement activities designed to reduce air pollution.4,5 Prevention and control of air pollution at its source is the primary responsibility of States and local governments. EPA's role includes (1) conducting research and development programs, (2) establishing standards and regulations to meet environmental goals under the Act, (3) providing support to State and local governments, and (4) ensuring effective enforcement of the standards and regulations.

The air program regulates two basic groups of pollutants: criteria pollutants and hazardous air pollutants. The emission of criteria pollutants from old ("existing") sources is controlled through State permits which specify emission levels needed to meet EPA's National Ambient Air Quality Standards (NAAQS). The emission of "designated" air pollutants from existing sources may be regulated under authority of Section 111(d). Control of criteria pollutants from new sources is regulated by Federal New Source Performance Standards (NSPS) pursuant to Section $111(b)$. National Emission Standards for Hazardous Air Pollutants (NESHAPs) are established by EPA to control emission of hazardous air pollutants from particular sources or operations pursuant to Section 112 . 
RCRA was developed by Congress to address the health and environmental hazaras posed by the improper management and disposal of municipal and industrial wastes. The goals of RCRA are to: (1) protect human health and the environment, (2) reduce waste and conserve energy and natural resources, and (3) reduce or eliminate the generation of hazardous wastes as expeditiously as possible.

Congress decided that wastes can pose qualitatively different degrees of hazard and therefore established two very different programs to accomplish the RCRA goals. Subtitle $C$ of RCRA was developed to regulate the management of wastes which require a high degree of control to prevent harm to human health or the environment. Under Subtitle $C$, wastes are controlled from generation to final disposal (i.e., "cradle to grave"). Subtitle C wastes are commonly called "hazardous wastes."

Subtitle D of RCRA was developed primarily to promote environmentally sound disposal methods for wastes which do not pose as great a hazard. $\dot{6}$ Another major objective of the Subtitle $D$ program is to encourage recycling or resource recovery. The Subtitle $D$ standards set out limited technical requirements on "solid" or non-hazardous waste facilities as compared to Subtitle C's comprehensive set of regulatory controls.

\section{EPA ORGANIZATIONAL ACTIVITIES}

Major organizations within EPA involved in activities related to MWC facilities include the Office of Air Quality Planning and Standards (OAQPS), the Office of Research and Development (ORO), and the Office of Solid Waste (OSW). A major function of the OAQPS is to develop air pollution emission control standards for stationary sources. The Emission Standards Division (ESD) is responsible for developing technical backyround information on which the MWC rules are to be based. They are also responsible for developing the specific provisions of the regulations and for writing and publishing the regulations. OAQPS is in. Durham, NC.

ORD is providing funds and technical support in the development of the MWC rules. The Air and Energy Engineering Research Laboratory (AEERL) is responsible for developing recommendations for yood combustion practices and for jointly supporting and managing field test projects which are used to collect the emission and pollution control technology performance data on which the MWC rules are to be based. The air pollution emission control activities discussed in the next section of this paper include the results of OAQPS and ORD activities. AEERL is in Research Triangle Park, NC.

OSW is responsible for the development of regulations and guidelines dealing with solid wastes. The Risk Reduction Engineering Laboratory (RREL), an ORD organization, supports OSW in conducting R\&D activities needed in the 
assessment and development of solid waste management technologies. OSW is located in Washington, $\mathrm{CC}$, and RREL is located in Cincinnati, $\mathrm{OH}$.

Urganizationally, AEERL and RREL report to the Office of Environmental Engineering and Technology Demonstration (UEETD), which has its headquarters in Washington, DC. OEETD directs the ORD research, development, and demonstration program related to MWC (the MWC program). AEERL is responsible for managing projects dealing with combustion and flue gas cleaning technology. RREL is responsible for managing projects dealing with MWC residues.

\section{AIR POLLUTION EMISSION CONTROL ACTIVITIES}

\section{DECISION TO DEVELOP NEW RULES}

Un July 7, 1987, an advanced notice of proposed rule making (ANPRM) was published in the Federal Register (52 FR 25399). 7 This notice from the EPA announced its intentions of reguta air pollution emissions from municipal waste combustion facilities under CAA Section 111. This decision was based, in part, on a comprehensive study of MWC. This comprehensive study was embodied in nine volumes; the summary volume was the "Municipal Waste Combustion Study: Report to Congress." 8 This MWC study involved the evaluation of health and environmental risks associated with MWC and an assessment of technology for limiting emissions of criteria and hazardous air pollutants either by control of the combustion process or by the use of flue gas cleaning technology.9,10,11

Concurrently with this ANPRM, OAQPS issued operational guidance to EPA's Regional Offices concerning approval of applications for permits (under prevention of significant deterioration and non-attainment new source review) to construct new incinerators. 12 These guidelines specified that all new incinerators use good combustion practice and the appropriate flue gas cleaning technology to ensure adequate control of air pollution einissions. Approriate flue gas cleaning technology was defined as the use of a dry scrubber in combination with a fabric filter (FF) baghouse or electrostatic precipitator (ESP). Although the criteria for achieving good combustion were not defined in the operational guidance, the Regional offices were referred to recommendations for good combustion provided in the report entitled "Municipal Waste Combustion Study: Combustion Control of Organic Emissions." 10

\section{REGULATORY PROCEDURE}

OAQPS is responsible for the development of air pollution emission standards for MWC facilities. The development of standards encompasses a number of formalized activities specified by the CAA, its amendments, and Agency procedures.4,5 Standards pursuant to Sections $111(\mathrm{~b})$ and $111(\mathrm{~d})$ are technology based rather than risk based. The NSPS must reflect the best degree of 
control available taking cost, energy, and non-air related environmental impacts into account. Standards for existing facilities [Section $111(\mathrm{~d})$ ] must take the remaining life of the facility into consideration.

OAUPS' first procedure in setting air emission rules under section 111 is to select the pollutants or classes of pollutants which are to be considered for control. After the pollutants are selected, then background information on the emission levels, costs, energy impacts, and non-air environmental impacts associated with a number of emission control strategies are developed. Each strategy is selected to provide a different level of emission control and hence cost. These control options and their associated environmental and economic consequences are presented to the Administrator who, in consultation with other EPA officials, selects one of the options or a combination of options. The selected option is expressed in terms of a proposed set of rules which are published to obtain public comment. After a period of public comment, the proposed rules are modified as deemed necessary by EPA before they are promulgated. If the rules are proposed under Section 111(b), they are promulgated as Federal Standards or-Regulations. If they are proposed under Section 111(d), they are promulgated as Guidelines and state governments are required to develop and enforce state regulations in accordance with the Guidelines.

\section{CONTROLLED POLLUTANTS}

MWC facilities emit a mixture of air pollutants of environmental concern. Table 1 lists the pollutants EPA evaluated for potential control in the studies which led to the decision to develop further air pollution emission rules for MWC facilities.7,9 These pollutants can be grouped into three main categories: acid gases, trace organics, and trace metals.

While pollutants may be identified by classes of chemical compound or other criteria, they may also be grouped by the methods used to control them; i.e., by combustion and flue yas cleaning control mechanisms. The easiest method of limiting emissions of organics is by the use of good combustion practices (GCP). Pollutants emitted from the combustor can be controlled by mechanisms operational in flue gas cleaning (FGC) devices. The collection of pollutants in FGC devices depends on differences in the physical, chemical, and electrical properties of pollutants. Many metals condense at stack gas temperatures and are collected as particulate matter (PM). Other metals must be adsorbed onto the surfaces of particles, or the flue gas temperature must be lowered sufficiently to result in condensation. Acid gases are collected by reaction with a sorbent which converts them to a solid.' They are then collected as PM. Condensed phase organics and semi-volatile organics are controlled in varying degrees by PM control devices. They are collected more effectively by methods used to control acid gases, condensation, adsorption, absorption, and particle collection. Volatile organics are difficult to control if they are not destroyed during combustion. 
To reduce the technical and cost problems associated with studying and regulating a multiplicity of elements, compounds, and other groups of pollutants, the following pollutants are used to represent direct control or surrogate control of the major MWC pollutants of concern:

- PM for trace metals, inorganic particulate matter, and condensed organics.

- Hydrogen chloride $(\mathrm{HCl})$ and sulfur dioxide $\left(\mathrm{SO}_{2}\right)$ for acid gases.

- Chlorinated dibenzo-p-dioxins (CDD) and chlorinated dibenzo-furans (CDF) for organics.

Although nitrogen oxides $\left(\mathrm{NO}_{\mathrm{x}}\right)$ are also a MWC emission of concern, studies relating to $\mathrm{NO}_{x}$ control are not covered in this paper.

MWC MODEL PLANT STUDIES

The control options considered by EPA must take into account reductions in air pollution emissions, pollution control costs, economic impacts, energy impacts, and non-air environmental impacts. These factors vary with the size of MWC plants, the type of combustor, the pollution control technology, age of the plant, and numerous other factors. Rather than study each existing and projected plant, a model plant study approach was taken to provide information needed for development of MWC air pollution emission regulations.

Two sets of model plants were developed: a set representing those which will be subject to NSPS and a set representing those subject to Guidelines. The NSPS and Guideline model plants were defined as:

1. Information was collected on existing and planned plants in the U.S. which will be subject to MWC emission Guidelines. This information included plant name and location, type of combustor(s), number of combustors, heat recovery provisions, plant size (tpd), year of start-up, and air pollution control device employed.

2. Projections were made of plants to be constructed during the 5-year period after the NSPS become effective. The projections included estimates of the combustor type, number of combustors, heat recovery provision, plant capacity, and air pollution control devices employed.

3. Model plants were defined for each major type of combustor in the Guideline and NSPS model plant sets. A "retrofit study" was performed in which combustion and FGC retrofits were developed for each of several air emission control technologies for each Guideline model plant. The costs of implementing these plant modifications were estimated and the associated air emission performance 
levels were defined. Similar design, cost, and performance studies were made for selected air pollution control techniques for each type of NSPS plant.

4. Estimates were made of the "baseline" air pollution emissions of concern. Baseline emissions are the estimated emissions which would result if EPA did not promulgate Guidelines or NSPS for MWC facilities. The "baseline" emission estimates for the model plants were based on the interpretation of all available field and pilot plant test data applicable to a given combustor type and FGC technology.

5. A number of air pollution emission control options were studied for the Guideline and NSPS model plants. These emission control options include the use of (1) GCP; (2) GCP and moderate PM control; (3) GCP and best PM control; (4) GCP, good acid gas control, and best PM control; and (5) GCP, best acid gas control, and best PM control. Emission control performance estimates for these control options were based on an interpretation of all available field and pilot plant test data applicable to each combustor type and FGC control option.

6. Environmental engineering studies were conducted in which the Guideline plant air pollution emission control options were applied to the set of model Guideline plants to provide estimates of emissions, costs, and non-air pollutant impacts. Similar studies were also conducted by applying the NSPS emission control options to the NSPS model plants.

Types of Combustors

EPA's municipal 1987 waste combustion study identified four classes of MWC facilities: mass burn incinerators, modular incinerators, refuse-derived fuel (RDF) combustors, and fluidized bed combustors.8,10 In subsequent EPA work, these classes have been expanded to additional sub-classes or types of combustors. Types of combustion systems for which model plants were developed include:

- mass burn, refractory, traveling grate ( $M B / R E F / T G$ )

- mass burn, refractory, reciprocating or rocking grate (MB/REF/RG)

- mass burn, refractory, rotary kiln (MB/REF/RK)

- mass burn, water wall, reciprocating or rocking or rolling grate (MB/WW/RG)

- mass burn, rotary combustor, water wall (MB/RC/WW) 


- modular incinerator, starved air (MI/SA)
- modular incinerator, excess air (MI/EA)
- (ouboling) fluidized bed combustor (FBC)
- circulating fluidized bed (CFB)

The characteristics of the combustion systems used for the Guideline and NSPS model plant studies are described in the following sections.

Guideline Plants

Thirteen classes of plants were considered for model Guideline plants when EPA began its "Retrofit Study" of existing sources in 1987. A summary of these plants showing the type of combustor, number of plants, and air pollution control devices employed is presented in Table 2.13 The majority of the mass burn and RDF plants employ. electrostatic precipitators for PM control. Only 8 of 44 starved air modular combustors employ PM control devices. Only two operating plants employed high-efficiency acid gas scrubber and PM control devices (spray dryer and fabric filters) at the beyinning of 1987. Six additional plants which incorporate spray dryers, dry sorbent injection in combination with fabric filter baghouses, or ESPs were to begin operation in 1987 or 1988. At least 39 of the 130 plants began operation before 1980 . Few of these plants are believed to employ GCP.

It is estimated that 330 individual combustors will be subject to the Section 111(d) emission guidelines. This includes combustors at both existing plants that are currently operating and "transitional plants" that were not operating as of March 1988, but will commence construction prior to November 1989, when the NSPS and emission guidelines will be proposed. The 330 combustors reflect an increase of about 30 percent in the number of existing combustors since publication of the June 1987 Report to Congress. It is estimated that, on a capacity basis, 68 percent of these $111(d)$ units will be mass burn facilities, 17 percent will be RDF, 5 percent will be modular, and 10 percent will be fluid bed combustors or unique designs not represented by model plants. In terms of number of combustors, 52 percent are mass burn, 8 percent are RDF, 30 percent are modular, and 10 percent are FGC or other unique designs. 14,15

Seventeen model plants were developed to represent the existing and transitional MWC population. These include three mass burn/refractory models, four mass burn/waterwall models, four RDFs, four modular, and two rotary waterwall models, listed in Table 3. The also shows the number of

The existing and transitional models represent each common type of combustor design. Some of the existing designs include good combustion practices $(G C P)$, while others do not. All models representing transitional MWCs are 
assumed to have GCP, since this is typical of newer units. The models were also selected to reflect the size ranges within each design type, the types of air pollution controls at existing and transitional facilities, heat recovery capabilities, and typical operating hours. While these models represent the great majority of existing and transitional combustors, it is estimated that four or more types of combustors are not now represented by model plants. Types of combustors which are not now represented include some batch-fed refractory wall combustors, a pulsating hearth combustor, a refractory wall rotary kiln combustor, and pulverized coal RDF combustors. There are also at least eight facilities with unknown combustor designs.

NSPS Plants

Municipal waste combustors that commence construction after proposal of the-NSPS (late 1989) will be considered "new" facilities subject to the new NSPS (Subpart Ea). Using projections of the growth in combustion of MSW developed by Franklin Associates, it is estimated that up to 40,000 tpd of new MWC capacity could become subject to the NSPS in the 5-year period after proposal (1990-1994). It is expected that about 115 new combustors will commence construction within this time period.

To project the distribution of new MWCs to be constructed, information on facilities in advanced planning or early construction stages was used, because it is expected that typical combustor types and plant sizes for new MWCs would be similar to MWCs that have been recently built or are under construction. These distributions indicate that, of the projected total design capacity subject to the NSPS, 64 percent will be mass burn, 26 percent RDF, 3 percent inodular, and 7 percent FBC facilities. In terms of the number of individual combustors, 58 percent will be mass burn, 18 percent RDF, 16 percent modular, and 8 percent FBC.14,15

Twelve different model plants were developed to represent new MWC facilities. New model plants were selected to represent each common type of combustor design and typical sizes were selected within each MWC design type. Where there was great size variation within a category (such as mass burn), model plants were developed for different combustor sizes (i.e., small, medium, and large). Other considerations in new model plant selection were annual operating hours and heat recovery ability. While most large new MWC plants are expected to operate continuously and produce steam and electricity for sale, some smaller modular and mass burn plants are expected to operate fewer hours or not to produce electricity.

The 12 model plants include 3 mass burn/waterwall, 1 mass burn/refractory, 1 mass burn/rotary combustor, 2 RDF, 1 modular excess air, 2 modular starved air, and 2 FBC facilities. These model plants are listed in Table 4. This table also shows the projected number of new facilities corresponding to each model plant. 
Emission Control Technology and Performance

EPA is considering various aproaches to controlling emissions from MWCs. One approach is to alter the combustion process to reduce emissions of organics including CDD/CDF, sometimes called combustion control or good combustion practice (GCP). A second approach is to add FGC equipment to control emissions of PM, metals, and acid gases, and obtain additional CDD/CDF contro.l. Another ajproach is to. use a combination of GCP and FGC control. The following sections provide emission performance estimates defined during EPA's model plant studies.

Combustion Control

Good combustion practices include the proper design, construction, operation, and maintenance of an MWC. The use of GCP can minimize emissions of CDD/CDF and their precursors by promoting more thorough combustion to destroy these pollutants.

High emissions of CDD/CDF are generally associated with poor combustion conditions; low CDD/CDF emissions, with good combustion. The combination of combustion conditions which are defined by those MWC design and operating conditions which result in low emission of CDD/CDF are called GCP. A major indicator of good combustion is the CO concentration in stack gas. Other combustion conditions which are postulated to be necessary to achieve low CDD/CDF emissions are discussed in the "paper entitled "Development of Good Combustion Practices to Minimize Air Emissions from Municipal Waste Combustors," which is included in the Proceedings of this conference.16

Following discharge from the combustor, additional CDD/CDF can form from precursors which have not been destroyed in the combustor in the presence of fiyash at temperatures ranging from approximately 480 to $660^{\circ} \mathrm{F}$ (250 to $\left.350^{\circ} \mathrm{C}\right) .17-20$ Destruction of precursors and minimizing the amount and residence time of PM in this temperature zone help to limit this secondary formation. An interpretation of field test data indicates that the in let temperature to PM control devices such as ESPs should be kept below $450^{\circ} \mathrm{F}$ to prevent significant secondary CDD/CDF formation in the control device.

The furnace formation of CDD/CDF is related to the design and operating conditions of MWCs. Table 5 summarizes estimates of current "baseline" and potentially achievable emissions of CCD/CDF and CO from different classes (types) of combustors now in operation in the U.S.21 The baseline emissions represent an upper bound for average emissions of all incinerators in a given sub-class. Estimates of potential achievable emissions which can be attained through the use of GCP are provided for both existing and new combustors.21,22 The emission estimates for existing combustors with GCP represent the performance levels which are believed attainable by combustion retrofits and by operating continuously with good combustion conditions. A range of $<500-1000$ $\mathrm{ng} / \mathrm{Nm}^{3}$ is estimated for some types of combustors. In these instances, there is currently insufficient information on the different combustors within each sub-class to make better estimates. Field test data available in the next 6 months should help provide more accurate estimates. 
New combustors which have begun operation within the last several years generally employ GCP. Alternatively, builders and operators are working to improve combustion conditions with the intent of achieving GCP. The estimates for new units represent performance levels which are believed to be attainable over the next several years.

PM Control

The most frequently used high performance PM control devices in the U.S. are electrostatic precipitators (ESPS) and fabric filters (FFs). These devices control particulate and fine particulate which may include metals and organics in particulate form. Althuugh other PM control technologies such as cyclones, electrified gravel beds, and venturi scrubbers are used at some MWC plants, they are infrequently applied and are not expected to be widely used at future MWC plants.

Existing pląnts have PM emissions ranging from 0.33 to less than $0.01 \mathrm{grl}$ dscf at $12 \% \mathrm{CO}_{2} \cdot 23-25$ The 1971 NSPS for MSW incinerators specifies a PH emission limit of $0.08 \mathrm{gr} / \mathrm{dscf.26}$ Plants which must meet standards for new industrial boilers must achieve an emission limit of $0.05 \mathrm{gr} / \mathrm{dscf} .27$ This level of control (0.08-0.05) is defined as moderate PM control. Large, welldesigned ESPs can achieve total PM emission levels of 0.01 gr/dscf or less. This PM performance level which is designated as best PM control can also be achieved by FFs.

Metals of concern emitted from MWC units include arsenic (As), beryllium $(\mathrm{Be})$, cadmium ( $\mathrm{Cd}$ ), chromium $(\mathrm{Cr})$, lead $(\mathrm{Pb})$, mercury $(\mathrm{Hg})$, and nickel ( $\mathrm{Ni}$ ). All of these metals, except $\mathrm{Hg}$, are removed by ESPS or FFs with the fine particulates. Data indicate that well-designed ESPs or FFs operated at $450^{\circ} \mathrm{F}$ or less remove over 97 percent of $A s, C d$, and $\mathrm{Pb}$ and about 99 percent of Be, $\mathrm{Cr}$, and $\mathrm{Ni}$ from MWC exhaust gases. 28 Because the metals content of MSW is variable, metals concentrations in the MWC exhaust gases vary from plant to plant. Because of great variability from plant to plant and the limited amount of metals test data for different plants, outlet metals concentration emission limits cannot be easily specified. However, it is believed that use of ESPs or FFs to comply with a sufficiently stringent PM emission limit and control of the flue gas temperature entering the PM control device will result in a high removal efficiency of the potentially toxic metals of concern, with the exception of $\mathrm{Hg}$.

Hg has a high vapor pressure and remains as a vapor in flue gas at temperatures at which ESPs have traditionally been operated in the U.S. MWC industry. The evidence is that little $\mathrm{Hg}$ control is achieved by ESPs whether. used alone or in conjunction with acid gas control Moderate to good $\mathrm{Hg}$ reduction can be achieved when FFs are used with acid gas control systems.

Semi-volatile organics such as CDD/CDF can be collected by PM control devices if they are adsorbed or condensed on the surface of particulate. Alternatively, results firom a number of field tests lead to the conclusion 
that COD/CDF can be formed in ESPs and granular oed filters if these control devices are operated at temperatures from 480 to $660^{\circ} \mathrm{F} .25$ Limited field data indicate that under certain conditions the inlet temperature of an ESP be low $450^{\circ} \mathrm{F}$ reduces the CDD/CDF concentration across the ESP from 50 to 75 percent.25 This and other data lead to the postulation that GCP and good PM control at an appropriate control device temperature can limit CDO/CDF emission levels to less than $500 \mathrm{ng} / \mathrm{Nm}^{3}$ for existing combustors and $300 \mathrm{ng} / \mathrm{Nm}^{3}$ for new combustors.* Tests to provide further evidence to corroborate these performance estimates were conducted in the Montyomery South Incinerator in Dayton, Onio, earlier this year. The results of these tests are to be available within the next several months. While FFs will probably not be used without acid gas control, it is believed that GCP and PM control with a FF will provide comparable or better performance than GCP with an ESP.

Estinated emission performance levels which are believed achievable with GCP and various levels of PM and acid gas control are summarized in Table 6.

\section{Good Acid Gas Control}

Dry sorbent injection (DSI) is being considered primarily as retrofit technology for use in existing MWC systems which currently use an ESP. DSI technology has been developed primarily to control acid gas emissions. However, when DSI is combined with flue gas cooling and an ESP, control of CDD/CDF, PM, and metal emissions are achieved. Two primary subsets of DSI technology exist. One approach, referred to as duct sorbent injection, involves injecting dry alkali sorbents such as hydrated lime into flue gas downstream of the combustor outlet and upstream of the PM control device. The second approach, referred to as furnace sorbent injection, injects sorbent directly into the combustor.

There are limited data on the performance of DSI systems. Existing facilities that have been retrofitted with GCP and then apply DSI/ESP systems are believed capable of CDD/CDF emissions of less than $125 \mathrm{ng} / \mathrm{Nm}^{3}$. New plants with DSI/FF systems are believed to be capable of achieving CDD/CDF emissions of less than $75 \mathrm{ng} / \mathrm{Nm}^{3} .25$

Dry sorbent injection systems can achieve a 40 percent reduction in $\mathrm{SO}_{2}$ emissions or an outlet $\mathrm{SO}_{2}$ concentration of 30 ppmv at 7 percent $0_{2}$. An 80 percent reduction in $\mathrm{HCl}$ emissions or an outlet concentration of $25 \mathrm{ppmv}$ is achievable. 25

PM emissions of less than $0.01 \mathrm{gr} / \mathrm{dscf}$ are believed to be achievable for MWCs equipped with DSI followed by ESPS.

Dry sorbent injection/ESP systems achieve 97 percent or greater removal of arsenic, cadmium, and lead, and 99 percent removal of beryllium, chromium, and nickel.29 Little mercury control is achieved by DSI/ESP systems, and no control is assumed for the control strategy studies.

* PM emission values are corrected to $12 \% \mathrm{CO}_{2} \cdot \mathrm{CDO} / \mathrm{CDF}, \mathrm{HCl}$, and $\mathrm{SO}_{2}$ emissions are corrected to $7 \% \mathrm{O}_{2}$. 
The emission control levels for GCP and good acid gas control which are used in MWC emission control scenarios are summarized in Table 6.

Best Acid Gas Control

Lime spray drying systems followed by FFs were initially developed to control $\mathrm{SO}_{2}$ and $\mathrm{HCl}$ emissions. However, the systems also control CDD/CDF, PM, and metal emissions including mercury. In the spray drying process, lime slurry is injected into the spray dryer and reacts with acid gases. The water in the slurry evaporates to cool the flue gas. The flyash and reaction products are removed by the FF. Spray dryer/fabric filter systems represent the best add-on control technology for MWCs currently used in the U.S.

Spray dryer/fabric filter systems can achieve outlet CDD/CDF concentrations of less than $10 \mathrm{ng} / \mathrm{Nm}^{3} .7$ They can also achieve an 85 percent reduction in $\mathrm{SO}_{2}$ emissions or an outlet concentration of $30 \mathrm{ppmv}$ at 7 percent $0_{2}$ and a 95 percent reduction in $\mathrm{HCl}$ emissions or an outlet concentration of $25 \mathrm{ppmv}$. PM emissions of less than $0.01 \mathrm{gr} / \mathrm{dscf}$ are believed to be achievable by MWCs equipped with SD/FF systens. 25

Typically, SD/FF systems achieve 99 percent removal of all metals except mercury. Mercury removal of 70 percent or greater is believed achievable for those design and operating conditions which provide for adequate temperature control and emission control of $\mathrm{SO}_{2}, \mathrm{HCl}$ and $\mathrm{PM}$.

The emission control levels of GCP and best acid gas control which are used in the MWC emission control levels are summarized in Table 6.

\section{EMISSION CONTROL SCENARIOS}

Cost studies have been completed for each model plant with each pollution control option. Emission control scenarios are now being formulated to study the aggregated cost effectiveness (national reduction of pollutant emissions versus cost) of using plant emission control options, which depend on plant size and plant age (existing versus new). The results of these and other studies will be integrated with energy and non-air environmental impact studies to form regulatory options for presentation to EPA's Administrator. It is expected that proposed MWC air. pollution emission control rules will be published in the Federal Register in November 1989.

\section{LEGISLATIVE ACTIVITIES}

Proposed legislation is before the 101 st Congress (S.196) to control air pollutant emissions from municipal waste incineration and provide for safe disposal of ash. 30 
The proposed air pollution control provisions: specify pollutants to be controlled; require the use of best available control (BACT) technoloyy on new sources; identify BACT deemed available for application to MWC iacilities; require the development of emission standards for both new and existing sources; and define minimum standards for combustion temperature and emission of $\mathrm{CO}, \mathrm{PM}, \mathrm{SO}_{2}$, and $\mathrm{HCl}$. This last provision would require the use of $\mathrm{GCP}$, acid gas control technology, and PM control technology on all new and existing units. EPA is to establish standards for new sources within 18 months of the effective date of the legislation. Existing sources are given 6 years from the effective date of the legislation to comply with the new air emission control requirements promulgated by EPA. There are provisions for extendiny the compliance date for some existing units.

The proposed ash disposal and management legislation defines general disposal, leachant collection, and monitoring requirements for bottom ash, flyash, or combined ash.

Key provisions of this proposed legislation are summarized in the following sections:

AIR POLLUTION

The EPA Administrator is to promulgate standards of performance for new and existing MWC sources no later than 18 months after enactment of the legislation. These regulations are to be authorized by amendment of the Clean Air Act.

No permits are to be issued for new incinerators until after an enforceable solid waste management plan has been submitted to an appropriate state official and until a plan for incinerator ash management has been submitted.

\section{New Sources}

New sources are to use best available control technology (BACT). Equipment deemed available for air emission control includes: "electrostatic precipitators, fabric filtration, spray dry scrubbers, negative air flow, and good combustion practices, including the availability of auxiliary fuel to maintain specific temperatures." "The Administrator may require new facilities to be constructed according to designs which allow for addition of selective catalytic reduction and other technologies as they become available."30

Promulgated standards are to "specify numerical emission limits for the following substances or mixtures: particulate matter (total and fine), opacity, sulfur dioxide, hydrogen chloride, oxides of nitrogen, carbon monoxide, lead, cadmium, mercury, halogenated organic compounds, dioxins, and dibenzo furans." Additionally, "the Administrator shall take into account the use of numerical standards or other methods to reduce the presence in air emissions or ash from a municipal waste incineration unit each of the additional substances: volatile organic compounds, beryllium, hydrogen fluoride, antimony, arsenic, 
oarium, chromium, cobalt, copper, nickel, selenium, zinc, polychlorinated biphenyls, chlorobenzenes, chlorophenols, and polynuclear aromatic hydro-

In no event are EPA's standards to allow:

- CO emissions yreater than 50 ppm on a 4-hour average. The EPA Administrator may allow a 100 ppm CO emission limit for RDF units equipped with spray dryers and fabric filters. (All emission limits are corrected to $\left.7 \% \mathrm{O}_{2}.\right)$

- PM enissions greater than $0.015 \mathrm{gr} / \mathrm{dscf}$.

- $\mathrm{SO}_{2}$ emissions greater tnan $40 \mathrm{ppm}$ on an 8-hour average, or less than a 70 percent reduction in emissions.

- $\mathrm{HCl}$ emissions greater than $30 \mathrm{ppm}$ on an 8-hour average or less than a 90 percent reduction in emissions.

- A minimum combustion temperature of less than $1800^{\circ} \mathrm{F}$ and a retention time of less than 1 second at fully mixed conditions. The Administrator may set different requirements for atmospheric fluidized bed combustors.

\section{Existing Units}

- Emission and performance standards are to be promulgated for existing units. The methods of control and the pollutants regulated are to be the same as those specified for new sources. Existing sources are given 6 years to comply with the standards as measured from the effective date of the legislation. EPA shall in no event allow:

- C0 emissions yreater than 100 ppm on an 8-hour average. The Administrator may set emission limits of 200 ppm for units which employ acid gas scrubbers and fabric filters.

- PM emissions greater than $0.02 \mathrm{gr} / \mathrm{dscf}$.

- $\mathrm{SO}_{2}$ emissions greater than $60 \mathrm{ppm}$ on an 8-hour average, or less than a 70 percent reduction in emissions.

- $\mathrm{HCl}$ entssions greater than $45 \mathrm{ppm}$ on an 8-hour average, or less than a 90 percent reduction in emissions.

- A combustion temperature of less than $1800^{\circ} \mathrm{F}$ and a retention time of less than 1 second at fully mixed conditions. 
The proposed bill requires EPA to promulgate regulations for the management, handling, storage, treatment, transportation, reuse, and recycling of ash from municipal waste incineration units. These regulations are to be promulgated under authority of an amendment to RCRA, sub-title D. They are to be issued within 18 months after the enactment of legislation. The regulations can apply to flyash separately, bottom ash separately, or combined bottom and flyash. require:

If ash is to be disposed of in landfills, then EPA's regulations are to

1. The installation of two or more composite liners with a leachate collection system above and below the liners, and leachant treatment.

2. Ground water monitoring.

If combined ash or bottom ash is to be disposed of in a monofill (a landfill containiny only ash from incinerators), then EPA regulations must require as a minimum:

1. The use of a single composite liner system, a leachant collection system, and leachant treatment.

2. Ground water monitoring.

If flyash is to be disposed of in a monofill which contains only flyash or substantially flyash, then the regulations may provide for two disposal options. If the flyash is treated prior to disposal by standards defined by EPA, then EPA disposal regulations must require as a minimum:

1. The use of a single composite liner system, a leachant collection system, and leachant treatment.

2. Ground water monitoring.

If flyash is not treated, then EPA disposal regulations must require as a minimum that the landfill be constructed with two liners, with a leachant detection system, leachant collection systems, and a leachant treatment system. 


\section{REFERENCES}

1. Allen Hershkowitz, Ph.D., "Garbaye Burning -- Lessons from Europe: Consensus and Controversy in Four European States," Inform, 1986, p.13.

2. Characterization of Municipal Solid Waste in the U.S. 1960-2000 (updated 1988), Franklin Associates, March 30, 1988.

3. The Solid Waste Dilemma: An Agenda for Action, Final Report of Municipal Solid Waste Task Force, U.S. Environmental Protection Agency, Uffice of Solid Waste, Wasninyton, D.C., February 1989.

4. The Clean Air Act, December 1970, P.L. 91-604.

5. The Clean Air Act as Amended August 1977, P.L. 95-95.

6. The Resource Conservation and Recovery Act, October 21, 1976, P.L. 94-580.

7. 40 CFR Federal Register, Vol. 52, No. 129, July 1987, pp 25399-25408.

8. U.S. Environmental Protection Agency, Municipal Waste Combustion Study: Report to Congress, EPA/530-SW-87-021a (NTIS PB87-206074), June 1987.

9. U.S. Environmental Protection Agency, Municipal Waste Combustion Study: Assessment of Health Risks Associated with Exposure to Municipal Waste Combustion Emissions, EPA/530-SW-87-021g, (NTIS PB87-206066), September 1987.

10. Seeker, W.R., W.S. Lanier, M.P. Heap, Municipal Waste Combustion Srudy: Combustion Control of Organic Emissions, EPA/530-SW-87-021C (NTIS PB87206090), June 1987.

11. Sedman, C.B., T.G. Brna, Municipal Waste Combustion Study: Flue Gas Cleaning Technology, EPA/530-SW-87-021d (NTIS PB87-206108), June 1987.

12. Operation Guidance on Control Technology for New and Modified Municipal Waste Combustors (MWCs), Memorandum from EPA/OAQPS's Gerald A. Emison to EPA Regional Offices, June 16, 1987.

13. Municipal Waste Combustion Industry Profile - Facilities Subject to Section III(d) Guidelines, U.S. Environmental Protection Agency, Office of Air Quality Planning and Standards, DCN No.88-239-003-31, Research Triangle Park, NC, September 16, 1988.

14. Personal communication from John Robinson, U.S. Environmental Protection Agency, Office of Air Quality Planning and Standards, Research Triangle Park, NC, March 8, 1989. 
References (contd.)

15. Personal communication from James U. Crowder, U.S. Environmental Protection Agency, Office of Air Quality Planning and Standards, March 8, 1989.

16. Nelson L.P., P. Schindler, J.D. Kilgroe, "Development of Good Combustion Practices to Minimize Air Emissions from Municipal Waste Combustors," Proceedinys, International Conference on Municipal Waste Combustion, Hollywood, FL, April 11-14, 1989.

17. Hagenmaier, H., H. Brunner, R. Haag, M. Kraft, Envir. Sci. and Tech., $21(11), 1987, \mathrm{p} 1085$.

18. Vogg, H., L. Stieglitz, Chemosphere, 15, 1986, p 1373.

19. Stieglitz, L., H. Vogg, Formation and Decomposition of Polychlorodibenzodioxins and -furans in Municipal Waste Report kfK4379, Laboratorium fur Isotopentechnik, Institut fur. Heize Chemie, Kernforschungszentruin Karlsruhe, February 1988.

20. Karesek, F.W., L.C. Dickson, Proceedings of the Municipal Waste Incineration Conference, Montreal, Canada, October 1987.

21. Combustion Control Memorandum: Existing Municipal Waste Combustors. Draft memorandum from Energy and Environmental Research Corporation to U.S. Environmental Protection Agency, Office of Air Quality Planning and Standards and the Office of Research and Development, Research Triangle Park, NC, October 31, 1988.

22. Combustion Control Memorandum: New Municipal Waste Combustors. Draft memorandum from Energy and Environmental Research Corporation to Office of Air Quality Planning and Standards and the Office of Research and Development, Research Triangle Park, NC, September 28, 1988.

23. U.S. Environmental Protection Agency, Municipal Waste Combustion Study: Emissions Data Base for Municipal Waste Combustors, EPA/530SW-87-02Ib (NTIS PB87-026082), June 1987.

24. Municipal Waste Combustion Retrofit Study, Draft Report from Radian Corporation and Energy and Environmental Research Corporation to U. S. Environmental Protection Agency, Industrial Studies Branch, Research Triangle Park, NC, September 15, 1988.

25. Vancili, M.A., D.M. White, Assessment of Add-on Control Technology Performance for New Municipal Waste Combustors, Draft Radian Report, prepared for Office of Air Quality Planning and Standards, DCN No. 88-239-003-31-07, Research Triangle Park, N.C., June 7, 1988. 
References (Contd.)

26. 40 CFR Part 60 , Subpart E, Standards of Performance for Incinerators, August $17, \cdot 1971$.

27. 40 CFR Part 60 , Subpart Db, Standards of Performance for New Stationary Sources: Industrial-Commercial-Institutional Steam Generating Units, June 19, 1984.

28. Brna, T.G., Comparison of Flue Gas Cleaning Systems for Municipal Waste Combustors, Municipal Solid Waste Conference, San Diego, CA, January 30 - February 1, 1989.

29. The National Incinerator Test and Evaluation Program: Air Pollution Control Technology, Environment Canada, Report EPS 3/UP/2, Ottawa, Ontario, September 1986.

30. S.196, To Control Emissions of Air Pollution from Municipal Waste Incineration Units; To Provide for the Safe Disposal of Ash Produced by Such Units and for Other Purposes, Inited States Senate, Burdick, Durenberger, and Moynihan, Introduced January 25, 1989. 
TP-3622

\author{
APPENDIX \\ Unit Conversion Factors
}

English

Engineering Unit

in.

$\mathrm{lb} / \mathrm{hr}$

$g r / d s c f$

tons/hr

${ }^{\circ} \mathrm{F}-32$
Multiplied By

$2.540 \times 10^{-2}$

$4.536 \times 10^{-1}$

$2.288 \times 10^{3}$

$2.268 \times 10^{2}$

$5.555 \times 10^{-1}$
Metric Unit

$m$

$\mathrm{kg} / \mathrm{hr}$

$\mathrm{my} / \mathrm{dscin}$

tonne/h

${ }^{\circ} \mathrm{C}$ 
TABLE 1. POLLUTANTS OF CONCERN

\begin{tabular}{lll} 
& & \multicolumn{2}{c}{ INORGANIC COMPOUNDS } \\
\cline { 2 - 3 } ORGANIC COMPOUNDS & METALS & ACID GASES \\
\hline & Arsenic & Hydrogen Chloride \\
Benzene & Beryllium & Hydrogen Fluoride \\
Benzo(a)pyrene (BaP) & Cadmium & Sulfur Dioxide \\
Carbon Tetrachloride & Chromium & \\
Chlorobenzenes & Copper & \\
Chlorodibenzodioxins & Lead & \\
Chlorodibenzofurans & ilercury & \\
Chloroform & Nickel & \\
Chlorophenols & Selenium \\
Formaldehyde & & \\
Naphthalene & & \\
Perchloroethylene & & \\
Phenol & & \\
Polychlorinated Biphenyls & &
\end{tabular}


TABLE 2. EXISTING MWC FACILITIES IDENTIFIED FOR RETROFIT STUDYa

\begin{tabular}{|c|c|c|c|}
\hline $\begin{array}{l}\text { Combustor } \\
\text { Type }\end{array}$ & $\begin{array}{r}\text { No.of } \\
\text { Plants } \\
\end{array}$ & $\frac{\text { Start-up }}{\text { Range }}$ & $\frac{\text { Dates }}{\text { Ave. }}$ \\
\hline $\begin{array}{l}M B / R E F / T G \\
M B / R E F / R G \\
M B / R E F / R K \\
M B / W W / R G \text { (LG) } \\
M B / W W / R G \text { (MD) } \\
M B / W W / R G \text { (SM) } \\
M B / R K / W W \\
R D F / S S \text { (LG) } \\
R D F / S S \text { (SM) } \\
M I / S A \text { (LG) } \\
M I / S A \text { (SM) }\end{array}$ & $\begin{array}{r}6 \\
10 \\
5 \\
7 \\
8 \\
9 \\
3 \\
4 \\
8 \\
14 \\
46\end{array}$ & $\begin{array}{l}1957-1980 \\
1955-1982 \\
1960-1985 \\
1975-1988 \\
1973-1987 \\
1967-1987 \\
1981-1987 \\
1981-1988 \\
1979-1988 \\
1971-1987 \\
1970-1988\end{array}$ & $\begin{array}{l}1968 \\
1969 \\
1971 \\
1984 \\
1982 \\
1983 \\
1985 \\
1985 \\
1984 \\
1983 \\
1977\end{array}$ \\
\hline AI/EA & 10 & $1972-1987$ & 1982 \\
\hline TOTALS & 130 & & \\
\hline
\end{tabular}

$\frac{\text { Number of Plants Using Indicated FGC Devices } C}{\text { SD/FF }}$

\begin{tabular}{|c|c|c|c|c|c|c|c|}
\hline NONE & WS & $\underline{E S P}$ & $\mathrm{FF}$ & DSI/FF & $\begin{array}{c}\mathrm{SD} / \mathrm{FF} \\
(\mathrm{SD} / \mathrm{ESP}) \\
\end{array}$ & $\mathrm{NI}$ & OTHER \\
\hline$=$ & 2 & 4 & - & - & - & - & - \\
\hline - & 3 & 7 & - & - & - & - & - \\
\hline - & 1 & 3 & - & - & 1 & - & - \\
\hline - & - & 5 & - & - & $1(1)^{\star}$ & - & - \\
\hline- & - & 6 & - & - & 2 & - & - \\
\hline - & - & 7 & - & 1 & 1 & - & - \\
\hline - & - & 2 & 1 & - & - & - & - \\
\hline - & - & 3 & - & - & 1 & - & - \\
\hline- & - & 6 & - & - & 2 & - & - \\
\hline 3 & - & 9 & 2 & - & - & - & - \\
\hline 37 & 1 & 4 & 1 & - & - & 1 & $\begin{array}{r}\operatorname{Cr}(1) \\
W S / F F(1)\end{array}$ \\
\hline 2 & - & 6 & - & - & - & - & $\operatorname{cr}(1)$ \\
\hline - & - & - & - & - & - & - & $\mathrm{EGB}(1)$ \\
\hline 42 & 7 & 62 & 4 & 1 & $B(1)^{\star}$ & 1 & 4 \\
\hline
\end{tabular}

* indicates one unit with SD/ESP 
(a) An additional 32 plants with other types of combustors or unknown types of coinbustors were subsequently identified and included in the list of plants existing as of 1988.

(b) $M B / R E F / T G$

$M B / R E F / R G$

$\mathrm{MB} / \mathrm{REF} / \mathrm{RK}$

$M B / W W / R G$

$M B / R K / W W$

RDF/SS

$M I / S A$

$M I / E A$

LG

MD

SM

- mass burn, refractory, traveling grate

- mass burn, refractory, reciprocating or rocking grate

- mass burn, refractory, rotary kiln

- mass burn, waterwall, reciprocating or rocking or rolling grate

- mass burn, rotary kiln, waterwall

- RDF, spreader stoker

- modular incinerator, starved air

- modular incinerator, excess air

- large

- medium small

(c) WS

WS
ESP
FF
DSI/FF
SD/FF
SD/ESP
$C Y$
WS/FF
EGB
$N I$

- wet scrubber

- electrostatic precipitator

- fabric filter baghouse

- dry sorbent injection + FF

- spray dryer + FF

- spray dryer + ESP

- cyclones

- wet scrubber + FF

- electrified gravel bed

- no information 
TABLE 3. MOOELS FOR EXISTING AND TRANSITIONAL. MWC PLANTS FOR SECTION 11 (d) EMISSION GUIUELINES

\begin{tabular}{|c|c|c|c|c|c|c|c|c|}
\hline $\begin{array}{l}\text { I.D. No. and } \\
\text { Combustor Typea }\end{array}$ & $\begin{array}{c}\text { Unit } \\
\text { Size } \\
\text { (tpd) } \\
\end{array}$ & $\begin{array}{c}\text { Units Per } \\
\text { Plant } \\
\end{array}$ & $\begin{array}{c}\text { Plant } \\
\text { Capacity } \\
\text { (tpd)c }\end{array}$ & $\begin{array}{l}\text { Energy } \\
\text { Recoveryd }\end{array}$ & $\begin{array}{c}\text { Baseline } \\
\text { Controlse } \\
\end{array}$ & $\begin{array}{r}\text { Represen- } \\
\text { tationf } \\
\end{array}$ & $\begin{array}{r}\text { Distribution } \\
\text { of Plantsy } \\
\end{array}$ & $\begin{array}{c}\text { Total } \\
\text { Capacity } \\
\text { (tpd) }\end{array}$ \\
\hline $\begin{array}{l}\text { 1. } \mathrm{MB} / \mathrm{REF} / \mathrm{TC} \\
\text { 2. } \mathrm{MB} / \mathrm{REF} / \mathrm{RG} \\
\text { 3. } \mathrm{MB} / \mathrm{REF} / \mathrm{RK} \\
\text { 4. } \mathrm{MB} / \mathrm{WW} / \mathrm{RG} \\
\text { 5. } \mathrm{MB} / \mathrm{WW} / \mathrm{RG} \\
\text { 6. } \mathrm{MB} / \mathrm{WW} / \mathrm{RG} \\
\text { 7. } \mathrm{RDF} / \mathrm{SS} \\
\text { 8. } \mathrm{RDF} / \mathrm{SS} \\
\text { 9. } \mathrm{MI} / \mathrm{SA} \\
\text { 10. } \mathrm{MI} / \mathrm{SA} \\
\text { 11. } \mathrm{MI} / \mathrm{EA} \\
\text { 12. } \mathrm{MB} / \mathrm{RC} / \mathrm{WW} \\
\text { 13. } \mathrm{MI} / \mathrm{EA} \\
\text { 14. } \mathrm{MB} / \mathrm{WW} \\
\text { 15. } \mathrm{RDF} / \mathrm{SS} \\
\text { 16. RDF/SS } \\
\text { 17. } \mathrm{MB} / \mathrm{RC} / \mathrm{WW}\end{array}$ & $\begin{array}{r}375 \\
120 \\
300 \\
750 \\
360 \\
100 \\
1,000 \\
300 \\
50 \\
25 \\
100 \\
250 \\
140 \\
100 \\
1,000 \\
300 \\
250\end{array}$ & $\begin{array}{l}2 \\
2 \\
3 \\
3 \\
3 \\
2 \\
2 \\
2 \\
3 \\
2 \\
2 \\
2 \\
3 \\
2 \\
2 \\
2 \\
2\end{array}$ & $\begin{array}{r}750 \\
240 \\
900 \\
2,250 \\
1,080 \\
200 \\
2,000 \\
600 \\
100 \\
50 \\
200 \\
500 \\
420 \\
200 \\
2,000 \\
600 \\
500\end{array}$ & $\begin{array}{l}N \\
N \\
N \\
S \\
S \\
S \\
S \\
S \\
S \\
N \\
S \\
S \\
S \\
S \\
S \\
S \\
S\end{array}$ & $\begin{array}{l}\text { ESP } \\
\text { WS } \\
\text { ESP } \\
\text { GCP, ESP } \\
\text { GCP, ESP } \\
\text { ESP } \\
\text { ESP } \\
\text { ESP } \\
\text { GCP, ESP } \\
\text { GCP } \\
\text { ESP } \\
\text { ESP } \\
\text { GCP, ESP } \\
\text { GCP, ESP } \\
\text { GCP, ESP } \\
\text { GCP, ESP } \\
\text { GCP, ESP }\end{array}$ & $\begin{array}{c}E \\
E \\
E \\
E \& T \\
E \& T \\
E \\
E \\
E \\
E \& T \\
E \& T \\
E \\
E \\
T \\
T \\
T \\
T \\
T\end{array}$ & $\begin{array}{r}3 \\
5 \\
3 \\
11 \\
27 \\
5 \\
2 \\
4 \\
11 \\
24 \\
5 \\
2 \\
3 \\
5 \\
4 \\
3 \\
4\end{array}$ & $\begin{array}{l}2,250 \\
1,200 \\
2,700 \\
24,750 \\
29,160 \\
1,000 \\
4,000 \\
2,400 \\
1,100 \\
1,200 \\
1,000 \\
1,000 \\
1,260 \\
1,000 \\
8,000 \\
1,800 \\
2,000\end{array}$ \\
\hline \multicolumn{3}{|c|}{ Not represented by a modelg } & & & & E\&T & 22 & 9,250 \\
\hline Total & & & & & & & 143 & 95,070 \\
\hline
\end{tabular}


a $M B / R E F / T G=$ mass burn refractory, traveling grate

$M B / R E F / R G$ = mass burn, refractory, reciprocating grate, or rocking grate

$M B / R E F / R K=$ mass burn, refractory, rotary kiln

$M B / W W / R G$ = mass burn, waterwall, reciprocating, or rocking, or rolling grate

RDF $/ S S=R D F$, spreader stoker

$M I / E A=$ modular incinerator, excess air

$M I / S A=$ modular incinerator, starved air

$\mathrm{MB} / \mathrm{RC} / \mathrm{WW}=$ mass burn, rotary combustor, waterwall

b Tons per day of MSW or RDF combusted per combustor. All model combustors burn 100 percent MSW or RDF.

C Tons per day of MSW or RDF combusted for the total plant. All model plants burn 100 percent MSW or RDF.

d $N=$ no energy recovery

$S=$ steam generation

e GCP $=$ good combustion practices

$E S P=$ electrostatic precipitator

$f \quad E=$ existing MWCs (operating as of March 1988)

$T=$ transitional MWCS (MWCs not operating as of March 1988, but under construction or expected to commence construction by November 1989, when Section 111 (d) emission guidelines are proposed).

g This includes some older plants that are of unique designs as well as FBCs. The inodels represent the most common existing and transitional MWC designs; however, no models were developed to represent unusual designs of which there are only one or two MWCs. 
TABLE 4. MODELS FOR NEW MWC PLANTS FOR SECTION ו ו(D) NSPS

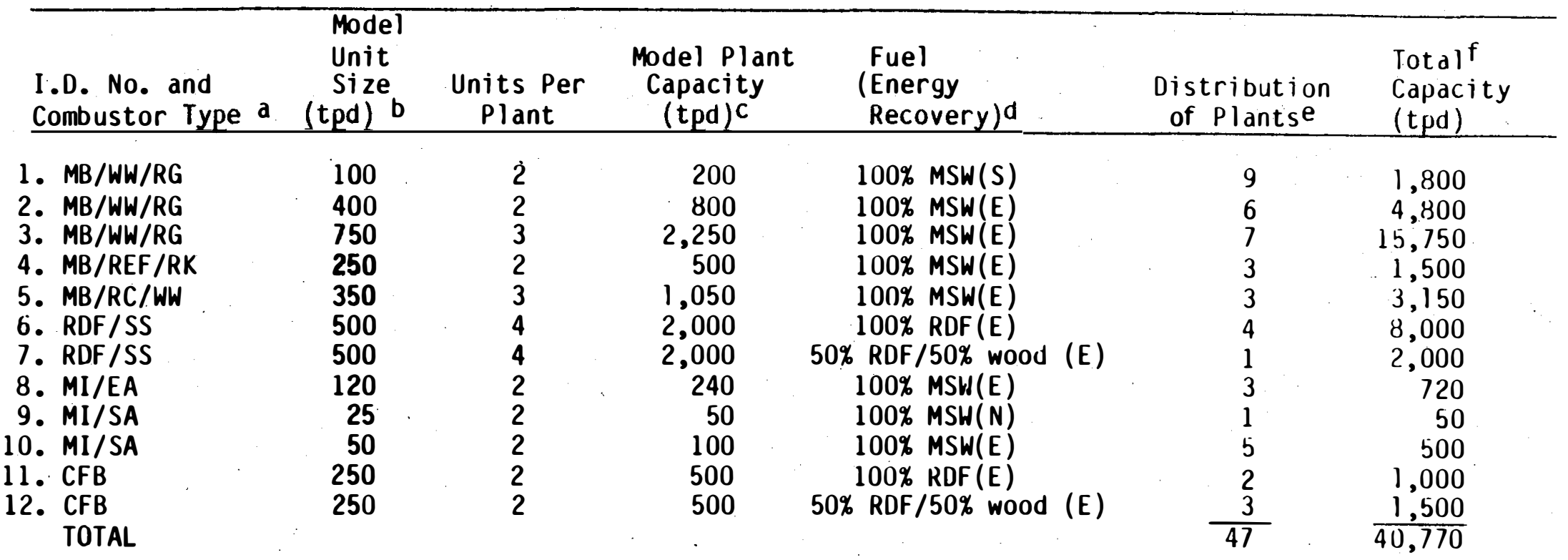

a $M B / W W / R G$ = mass burn waterwall, reciprocating, or rocking or rolling grate

$M B / R E F=$ mass burn refractory, rotary kiln

$\mathrm{MB} / \mathrm{RC} / \mathrm{WW}$ = mass burn rotary combustor/waterwall

KDF $=$ RDF, spreader stoker

$M I / E A=$ modular incinerator/excesc air

$M I / S A=$ modular incinerator/starved air

CFB = circulating fluidized-bed

b Tons per day of waste (or other fuel) combusted per combustor.

C Tons per day of waste (or other fuel) combusted for the total plant.

d $S$ = steam generation, $E=$ electricity generation, $N=$ no energy recovery.

e Plants expected to commence construction in 5-year period after proposal of NSPS (1990-1994).

f $24 \mathrm{hr} /$ day $X 333$ days $/ y r=8,000 \mathrm{hr} / \mathrm{yr}$ for $\mathrm{E}$ plants

$100 \mathrm{hr} / \mathrm{wk} \times 50 \mathrm{wk} / \mathrm{yr}=5,000 \mathrm{hr} / \mathrm{yr}$ for $\mathrm{N}$ and $S$ plants 
TABLE 5. ESTIMATES OF ACHIEVABLE EMISSION PERFORMANCE FOR CDD/CUF AND COA

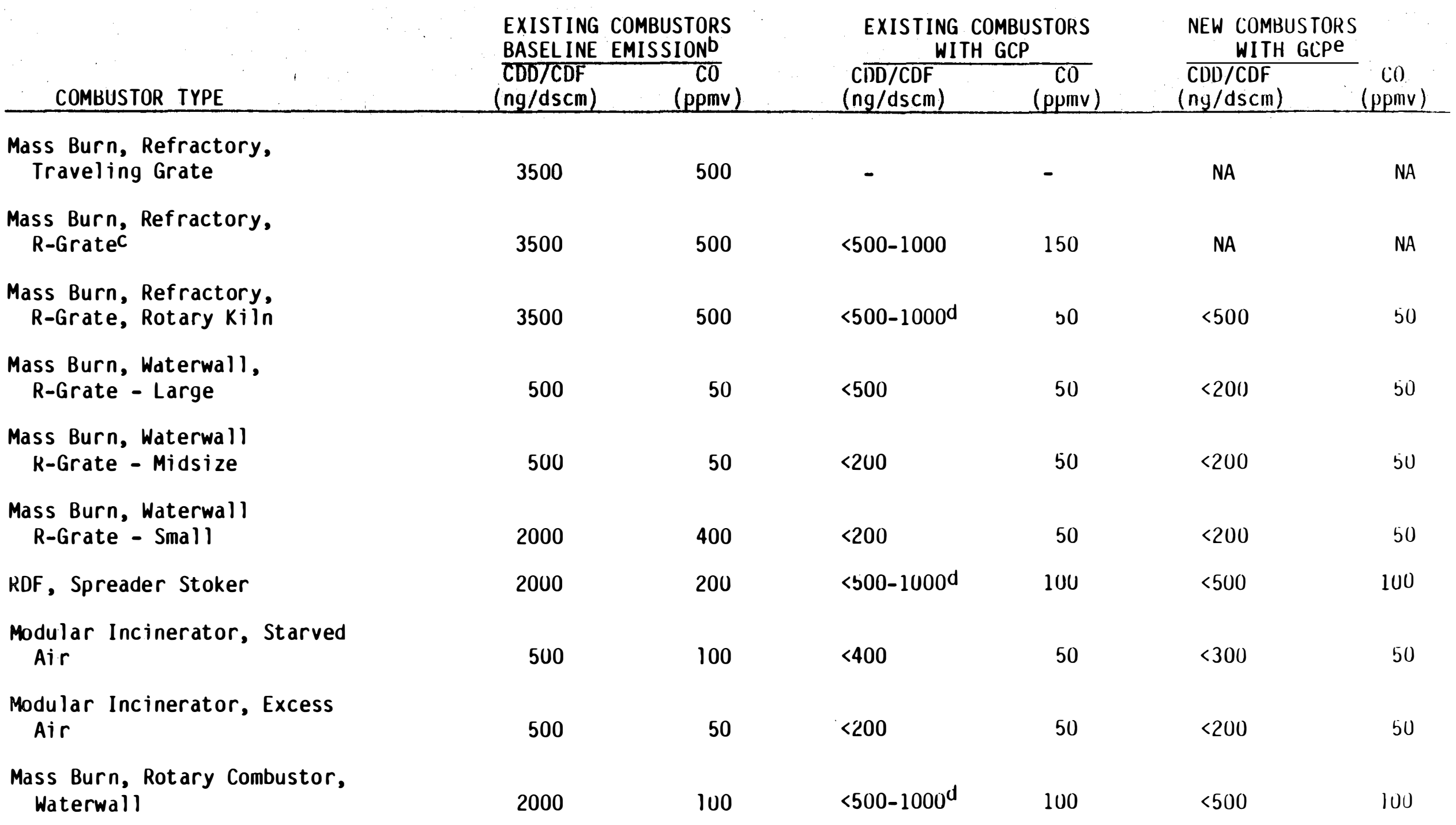

(a) Estimate of achievable Cu emission limits for all combustors in each sub-class (type).

(b) CDD/CDF baseline estinates are an upper bound for average emissions of all combustors of a given type.

(c) $R$-Grate = reciprocating, rocking or rolling grate.

(d) Field test data available within the next several inonths will provide for inproved estinates.

(e) Values believed achievable by continued improvement of combustion control measures. 
TABLE 6. ESTIMATED MWC CONTROL TECHNOLOGY LEVELS FOR GUIDELINE AND NSPS MODEL PLANTS

\section{ESTIMATED AVERAGE ACHIEVABLE EMISSION PERFORMANCE}

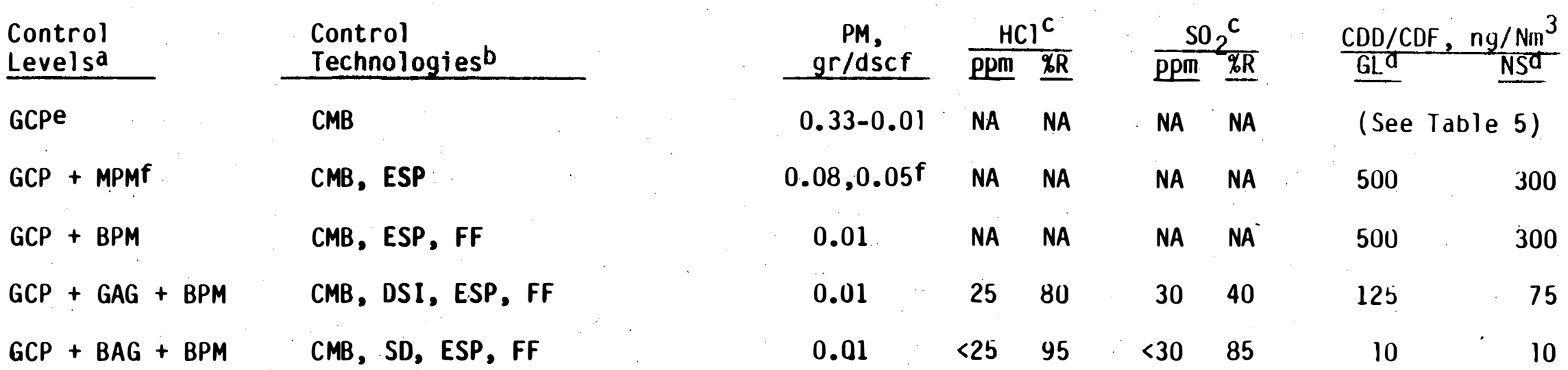

(a) $\mathrm{GCP}=$ good combustion practice, $\mathrm{MPM}=$ moderate $P M, B P M=$ best $P M, G A G=$ good acid gas, $B A G=$ best acid gas.

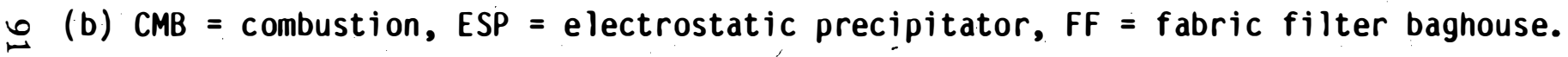

(c) $\mathrm{HCl}$ and $\mathrm{SO}_{2}$ performance levels depend on inlet values. PPM = achievable emission limit with normal inlet values, $\% R=$ maximum required removal efficiency with high inlet values.

(d) Model plant application: GL = Guideline plant, NS = NSPS plant

(e) GCP for existing plants only

(f) $M P M=0.08 \mathrm{gr} / \mathrm{dscf}$ for existing plant and 0.08 or $0.05 \mathrm{gr} / \mathrm{dscf}$ for NSPS plant depending on unit size 


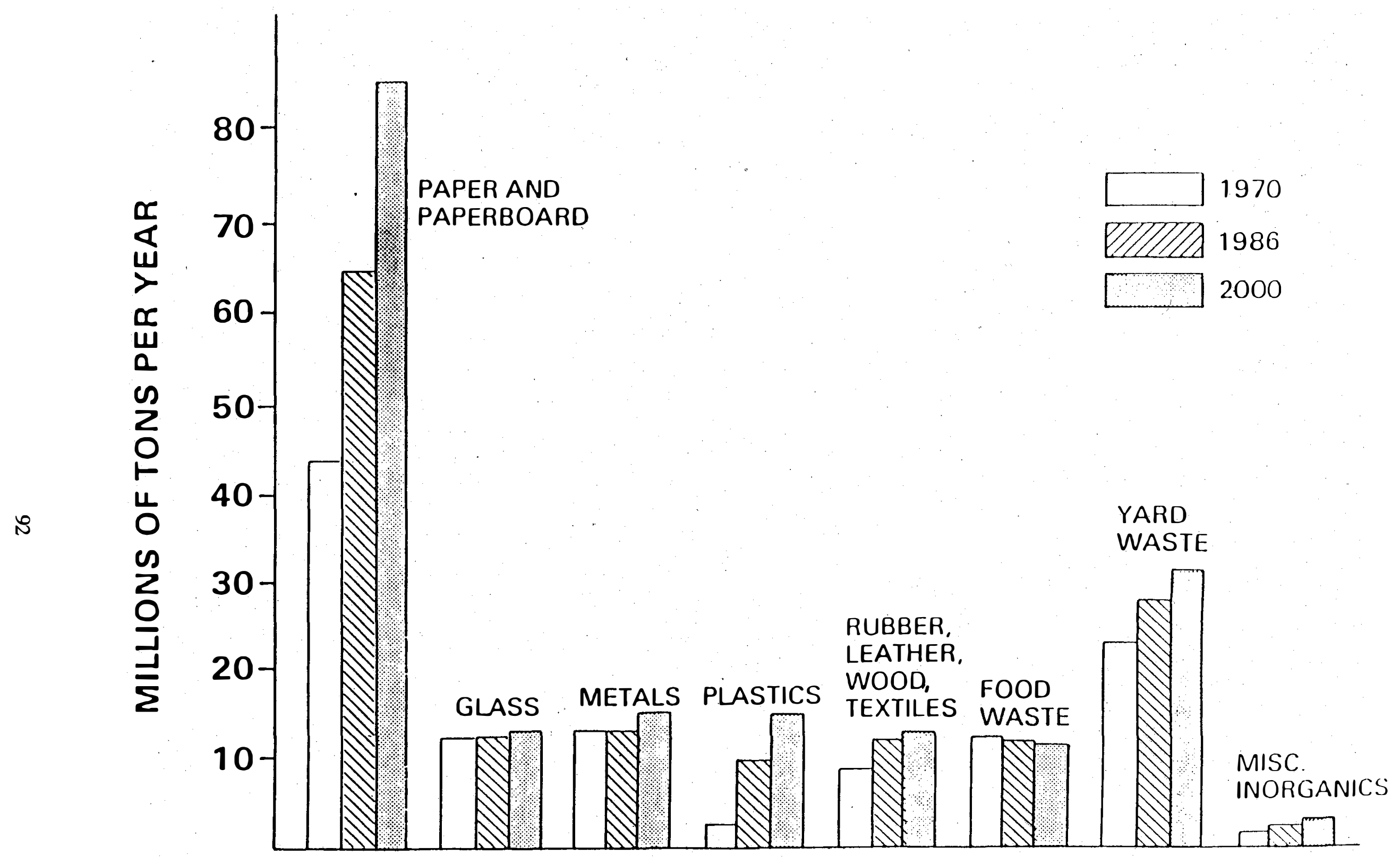

GROSS DISCARDS OF MATERIALS IN MSW

Figure 1. Trends in MSW Materials2 
Appendix F

Bibliography 
"Arizona." (1987). The Encyclopedia Americana. Danbury, CT: Grolier, Inc.; Volume 2, pp. 198-304.

Beckman, Arthur H., Design, Construction, and Operation of a 400 TPD Mass Burn MSW-to-Energy Plant - A Case History; (Draft). 11 pp. Work performed by Katy-Seghers, Inc., St. Louis, Missouri.

Brunner, Calvin R., and Courtney H. Brown. (October 1988). "Hospital Waste Disposal by Incineration." Waste Age (38:10); pp. 1297-1309.

Characterization of Municipal Solid Waste in the United States 1960-2000. (July 25, 1986). PB87178323. Chicago, IL: PRC Engineering, Inc.; 60 pp., prepared for the Environmental Protection Agency, Washington, DC, by Franklin Associates, Limited, Prairie Village, Kansas.

Characterization of Municipal Solid Waste in the United States 1960-2000. (Update 1988). (March 1988). PB88-232780; EPA/530-SW-88-033. 31 pp., prepared for the Environmental Protection Agency, Washington, DC, by Franklin Associates, Limited, Prairie Village, Kansas.

Governmental Advisory Associates, Inc., Materials Recovery and Recycling Yearbook, Directory and Guide, New York: Governmental Advisory Associates, Inc.

Hopper, Richard. (July 1985). Thermal Systems for Conversion of Municipal Solid Waste, Volume 3; Small-Scale Systems: A Technology Status Report. ANL/CNSV-TM-120-Vol. 3; pp. 38-45, 131-141. Prepared for Argonne National Laboratory, Argonne, Illinois, by Battelle Columbus Laboratories, Columbus, Ohio.

Kilgroe, James D. (April 1989). "U.S. Regulatory, Research, and Legislative Activities Related to MWC Facilities." Presented at the International Conference in Municipal Waste Combustion, Hollywood, Florida, April 11-14, 1989.

Landfill Capacity in the Year 2000. Washington, DC: National Solid Waste Management Association; $5 \mathrm{pp}$.

Municipal Waste Management Issues in the State of North Dakota: Final Report. (May 3, 1989). 50 pp. Submitted to Governor George A. Sinner by the North Dakota Waste Management Task Force.

"Nebraska." (1988). The Encyclopedia Americana. Danbury, CT: Grolier, Inc.; Volume 20, p. 43.

"Nevada." (1988). The Encyclopedia Americana. Danbury, CT: Grolier, Inc.; Volume 20, p. 141.

"New Mexico." (1988). The Encyclopedia Americana. Danbury, CT: Grolier, Inc.; Volume 20, p. 207.

"North Dakota." (1988). The Encyclopedia Americana. Danbury, CT: Grolier, Inc.; Volume 20, p. 442.

"Oklahoma." (1988). The Encyclopedia Americana. Danbury, CT: Grolier, Inc.; Volume 20, p. 693.

Pettit, C.L. (1988). NSWMA Annual Tip Fee Survey, 1988. Washington, DC: National Solid Waste Management Association; 4 pp. Reprinted from Waste Age magazine, March 1989 (20:3); pp. 101-105

"Resource Recovery Round-Up." (May 1989). NSWMA Facts on File (2:2); 4 pp. 
Solid Waste Dilemma: An Agenda for Action. (February 1989). EPA/530-SW-89-019. Washington, DC: U.S. Environmental Protection Agency; 70 pp.

Solid Waste Disposal Overview. Washington, DC: National Solid Waste Management Association; $4 \mathrm{pp}$.

"Utah." (1988). The Encyclopedia Americana. Danbury, CT: Grolier, Inc.; Volume 20, p. 829.

Who's Who in Energy Recovery from Waste. (February 1989). DOE/CE/39844-H1. 41 pp. Prepared for U.S. Department of Energy, Office of Conservation and Renewable Energy, Office of Renewable Energy Technologies, Biofuels and Municipal Waste Technology Division, Washington, DC, by Science Applications International Corporation, Alexandria, Virginia. 


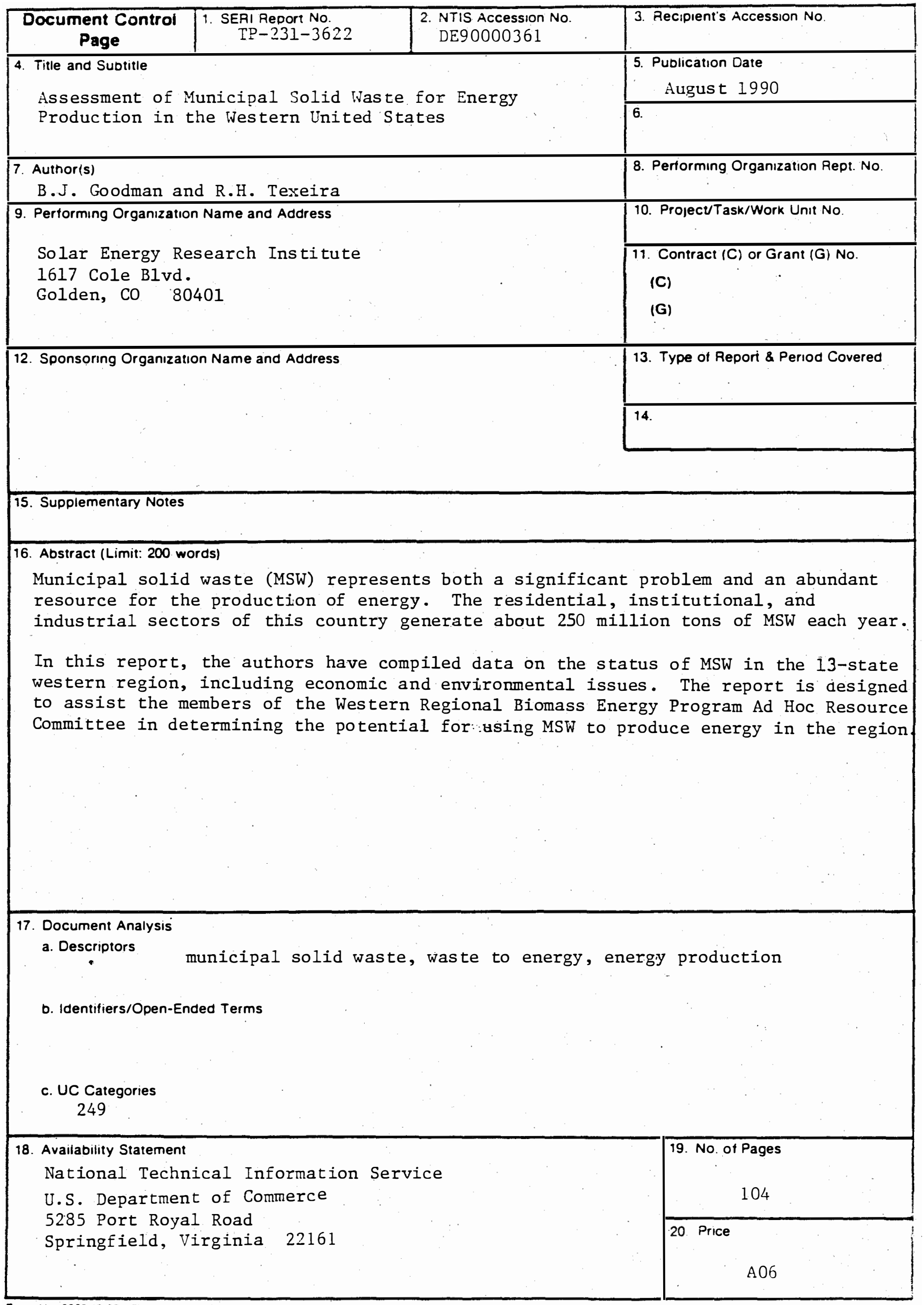

